\title{
GESTÃO DE RECURSOS HuMANOS COMO FATOR ESTRATÉGICO DA GESTÃO DO CONHECIMENTO: ESTUDO DE CASO EM UMA EMPRESA DO SETOR FARMACÊUTICO
}

Dissertação apresentada à Escola de Engenharia de São Carlos da Universidade de São Paulo, como parte dos requisitos para obtenção do título de mestre em Engenharia de Produção.

Orientador: Prof. Dr. Fernando César Almada Santos

SÃO CARLOS

2004 
À minha mãe,

pelo apoio durante toda minha vida. 


\section{Agradecimentos}

Às pessoas de que de alguma forma contribuíram para que este trabalho fosse concluído, como a amiga Márcia que foi grande incentivadora desde o início.

Em especial ao Prof. Dr. Fernando César Almada Santos, que, além de orientador, é um exemplo de dedicação profissional a se seguir.

Aos gerentes da empresa que trabalho que possibilitaram a realização deste curso.

À minha namorada, Maria Teresa, pelo seu apoio em todos os momentos e também pela compreensão das abdicações que tivemos.

Aos professores e funcionários do departamento de Engenharia de Produção. 


\section{RESUMO}

CASTANHA, Márcio. Gestão de recursos humanos como fator estratégico da gestão do conhecimento: estudo de caso em uma empresa do setor farmacêutico. São Carlos, 2004. 146 p. Dissertação (Mestrado) Escola de Engenharia de São Carlos, Universidade de São Paulo.

As mudanças no ambiente empresarial têm acontecido em uma freqüência cada vez maior e as organizações buscam formas de aumentar suas capacidades de adaptação e, conseqüentemente, sua competitividade no mercado. Neste sentido, tem se relacionado a obtenção de vantagem competitiva com o tratamento que a empresa dá aos seus funcionários e aos seus ativos intelectuais, como o conhecimento. É dentro deste enfoque, que as organizações têm empregado ferramentas de gestão do conhecimento. A partir dessa constatação, este trabalho procura observar a gestão de recursos humanos como fator estratégico para a gestão do conhecimento. Para tanto, foi realizado inicialmente, uma revisão na literatura, que permitiu o desenvolvimento de questões para analisar a influência da gestão de recursos humanos em iniciativas em gestão do conhecimento. É também realizado um estudo de caso para observar na prática as constatações da literatura. A pesquisa identificou que a área de recursos humanos pode contribuir efetivamente, através de práticas e políticas, para que esforços em gestão do conhecimento sejam bem sucedidos.

Palavras-chave: gestão do conhecimento, gestão de recursos humanos, competências. 


\begin{abstract}
CASTANHA, Márcio. Gestão de recursos humanos como fator estratégico da gestão do conhecimento: estudo de caso em uma empresa do setor farmacêutico. São Carlos, 2004. 146 p. Dissertação (Mestrado) Escola de Engenharia de São Carlos, Universidade de São Paulo.

The changes of the organizational environment have happened with a high frequency and the organizations search for ways to improve their capacities of adaptation and, consequently, their competitiveness in the market. In this way, the gain of competitive advantage is related to treatment that the company gives for their employees and for their intellectual assets, like the knowledge. Within this context the organizations have utilized tools of knowledge management. Following this argument, this work discusses the human resources management as strategic factor for the knowledge management. It was initially accomplished a literature revision, that allowed the development of subjects to analyze the influence of human resources management in the initiatives of knowledge management. This work also presents a case study that discusses in practice the observations from the literature. The research identified that the human resources department can effectively contribute, through policies and practices, for success of knowledge management implementation.
\end{abstract}

Key words: knowledge management, human resources management, competencies. 


\section{LISTA DE FIGURAS}

Figura 3.1 Componentes da gestão do conhecimento .............................................. 35

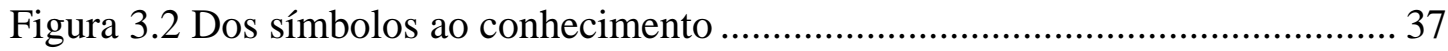

Figura 3.3 As competências na organização ............................................................. 44

Figura 3.4 As quatro formas de conversão do conhecimento ................................... 56

Figura 4.1 Modelo conceitual sobre gestão do conhecimento na empresa ................. 71

Figura $4.2 \mathrm{O}$ fluxo das capacidades organizacionais ................................................. 74

Figura 4.3 Circuito simples e circuito duplo de aprendizagem.................................. 80

Figura 4.4 Modelo do processo de aprendizagem organizacional .............................. 81

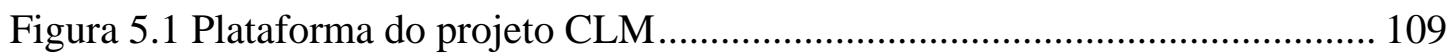

Figura 6.1 O CLM no contexto organizacional ..................................................... 130 


\section{LISTA DE QUADROS}

Quadro 2.1 características-chave de quatro sociedades básicas............................ 17

Quadro 2.2 Alocação da força de trabalho nas eras econômicas ........................... 28

Quadro 3.1 Competências individuais e organizacionais ...................................... 46

Quadro 3.2 Transferência do conhecimento: possíveis atritos e soluções.............. 58

Quadro 3.3 Propósito e valores da empresa Merck .............................................. 63

Quadro 3.4 Condições para a criação e transferência do conhecimento................. 70

Quadro 4.1 Os papeis da área de recursos humanos na gestão do conhecimento.. 72

Quadro 4.2 Arquitetura para o diagnóstico organizacional ................................... 76

Quadro 4.3 Ligando estratégia com práticas de recursos humanos. ...................... 78

Quadro 4.4 Diagnosticando como as práticas de recursos humanos estão alinhadas com o contexto organizacional: cinco fatores.................................. 89

Quadro 5.1 Organograma da empresa estudada............................................... 102

Quadro 5.2 Organograma da área de recursos humanos da empresa estudada.... 102

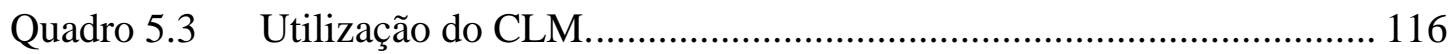




\section{SUMÁRIO}

RESUMO

ABSTRACT

LISTA DE FIGURAS

LISTA DE QUADROS

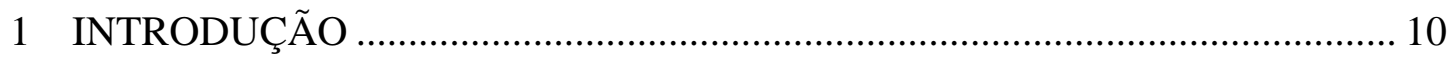

1.1 Justificativa e importância do estudo ......................................................... 12

1.2 Definição do problema da pesquisa ........................................................... 13

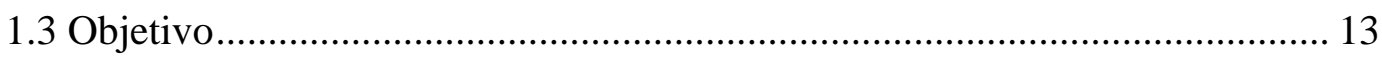

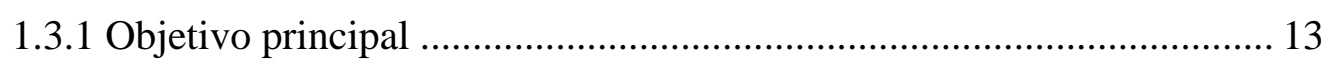

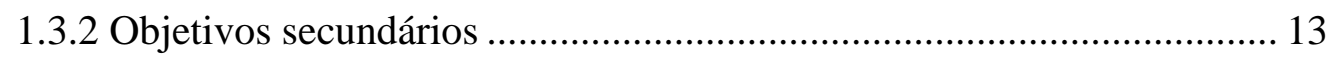

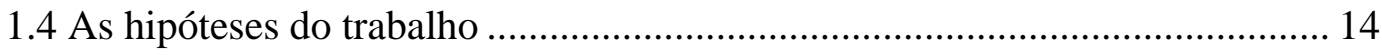

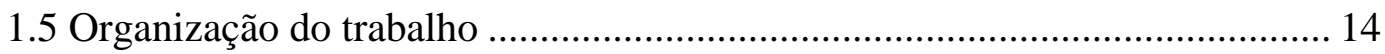

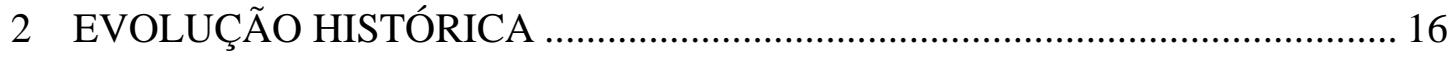

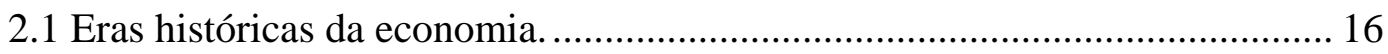

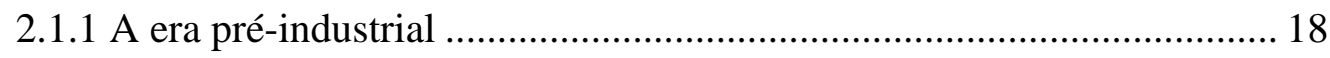

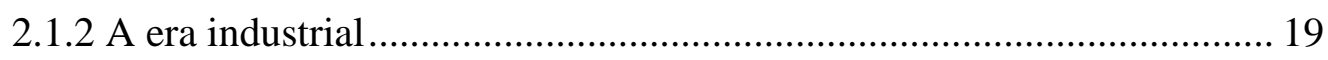

2.2 O desvendar dos mistérios dos artesãos e a Revolução Industrial .................. 19

2.3 Taylor e a revolução da produtividade............................................................ 21

2.4 A era e a sociedade do conhecimento ............................................................ 25

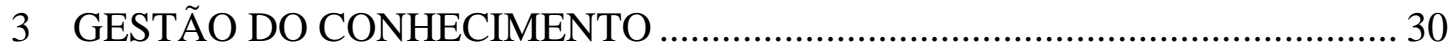

3.1 Gestão do conhecimento: uma delimitação.................................................... 31

3.2 Dados, informações e conhecimento. ........................................................... 36

3.3 Conhecimento e competências: o capital humano. ........................................ 42

3.4 Elementos da gestão do conhecimento. ......................................................... 49

3.4.1 Identificação do conhecimento. ........................................................ 50

3.4.2 Codificação e transferência do conhecimento......................................... 54

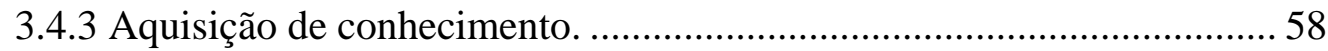

3.4.4 Criação de conhecimento: as condições capacitantes........................... 59

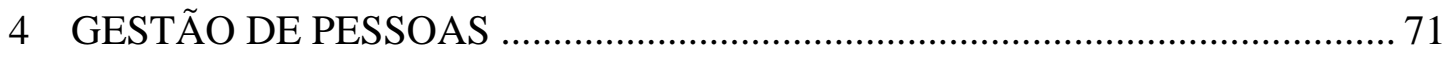

4.1 Recursos humanos como parceiro estratégico: a criação da clareza estratégica 
4.2 Recursos humanos e o aumento das competências e do comprometimento dos funcionários: a criação do capital humano. 79

4.3 Recursos humanos como agente da mudança cultural. 87

4.4 Gestão de pessoas para a gestão do conhecimento: constatações da literatura 90

5 ESTUDO DE CASO 93

5.1 Metodologia da pesquisa........................................................................... 93

5.1.1 Classificação do estudo ................................................................. 93

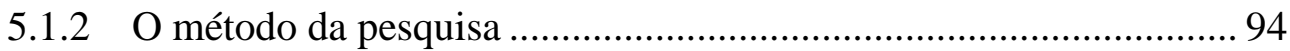

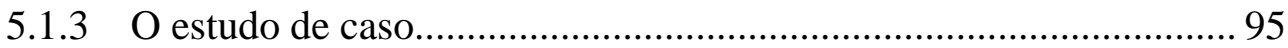

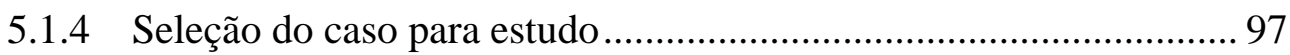

5.1.5 Fontes de dados e de informações e procedimentos de campo ........ 97

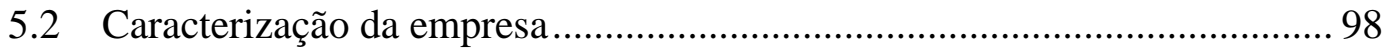

5.2.1 A área de recursos humanos no Brasil ........................................... 101

5.2.2 As iniciativas em gestão do conhecimento ................................... 105

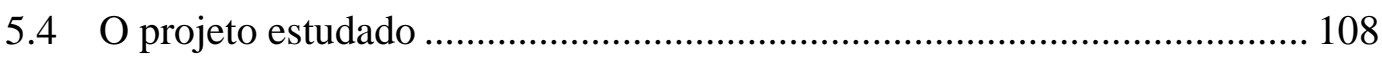

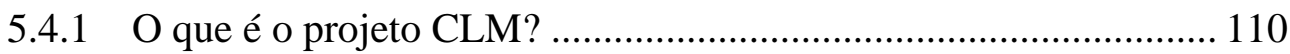

5.4.2 A percepção do projeto CLM pelos usuários................................. 113

5.4.3 A percepção do projeto pela alta administração ............................. 119

5.5 Considerações finais .............................................................................. 123

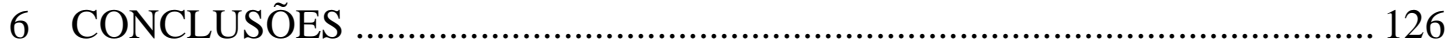

\section{REFERENCIAS}

APÊNDICE A - Roteiro de entrevistas com o gerente de recursos humanos APÊNDICE B - Roteiro de entrevistas com o gerente de tecnologia de informação APÊNDICE C - Roteiro de entrevistas com os gerentes de vendas, produto, pesquisa clínica e produção

APÊNDICE D - Roteiro de entrevistas com o diretor de unidade de negócios 


\section{REFERÊNCIAS}

AGOSTINHO, O.L. Sistemas de manufatura. Escola de Engenharia de São Carlos. / no prelo/ 2002.

AMARAL, C.E. Sistematização da gestão do conhecimento técnico na geração de princípios de solução na fase de reprojeto conceitual de produtos. Dissertação (Mestrado). Florianópolis: Universidade Federal de Santa Catarina - UFSC, 2001.

AMARAL, D.C. Arquitetura para o gerenciamento de conhecimentos explícitos sobre o processo de desenvolvimento de produto. Tese (Doutorado). São Carlos: Escola de Engenharia de São Carlos EESC - USP, 2002.

ALLIPRANDINI, D.H. e SILVA, S.L. Aprendizagem organizacional e gestão do conhecimento. In: Fábrica do futuro. São Paulo: Banas, 2000.

ANTUNES, M.T.P. Contribuição ao entendimento e mensuração do capital intelectual. Dissertação (Mestrado). São Paulo: Faculdade de Economia, Administração e Contabilidade FEA-USP, 1999.

ARGYRIS, C. On organizational learning. Cambridge: Balckwell, 1992.

BARCLAY, R.O. e MURRAY, F.C. What is knowledge management? Knowledge Praxis Magazine, http://www.media-access.com/whatis.html (08/Set), 2002.

BARNEY, J.B. Firm resources and sustained competitive advantage. Journal of Management. v.17, n. 1, p. 99-120, 1991.

Looking inside for competitive advantage. Academy of Management Executive, v. 9, n. 4, p. 49-61, 1995.

BARON, J.N. e KREPS, D.M. Consistent human resource practices. California Management Review, v. 41, n. 3, p. 29-53, Spring 1999.

BROWN, J.S., DUGUID, P. Organizing knowledge. California Management Review, v.40, n.3, p.90-111, Spring, 1998. 
CAMPOMAR, M.C. Do uso de "estudo de caso" em pesquisas para dissertações e teses em administração. Revista de Administração, São Paulo, v. 26, n.3, p.95-97, jul./set. 1991.

CANÊDO, L.B. A evolução industrial. Campinas: Unicamp, 1987.

CASTANHA, M., SANTOS, F.C.A. Gestão de recursos humanos como fator estratégico da gestão do conhecimento. In: Encontro Nacional de Engenharia de Produção, Ouro Preto, 2003. Anais.

CASTELLS, M. A sociedade em rede. (A era da informação: economia, sociedade e cultura v.1) 5.ed. São Paulo: Paz e Terra, 1999.

CAVALCANTI, M., GOMES, E., PEREIRA, A. Gestão de empresas na sociedade do conhecimento: um roteiro para ação. 5.ed. Rio de Janeiro: Campus, 2001.

CHIAVENATO, I. Teoria da administração. 5.ed. São Paulo: Makron Books, 1997.

COLLINS, J.C. e PORRAS, J.I. Building your company's vision. Harvard Business Review, v. 74, n. 5, p. 65-77, Sep./Oct. 1996.

COME, G. Contribuiçao ao estudo da implementação de data warehousing: um caso no setor de telecomunicações. Dissertação (Mestrado), FEA-USP, São Paulo, 2001.

CRAWFORD, R. Na era do capital humano. São Paulo: Atlas, 1993.

DAVENPORT, T.H. e PRUSAK, L. Conhecimento empresarial: como as organizações gerenciam o seu capital intelectual. 5.ed. Rio de Janeiro: Campus, 1998.

DRUCKER, P.F. Sociedade pós-capitalista. São Paulo: Publifolha, 1999. 1999b.

. Managing oneself. Harvard Business Review, v.77, n. 3, p. 64-74, mar./apr.

EDVINSSON, L. e MALONE, M.S. Capital intelectual: descobrindo o valor real de sua empresa pela identificação de seus valores internos. São Paulo: Makron Books, 1998.

FAHEY, L. e PRUSAK, L. The eleven deadliest sins of knowledge management. California Management Review, v.40, n.3, p.265-276, Spring, 1998.

FLEURY, M.T.L. O desvendar da cultura de uma organização - uma discussão metodológica. In: FLEURY, M.T.L, FISCHER, R.M. (Orgs.). Cultura e poder nas organizações.2.ed. São Paulo: Atlas, 1996. 
FLEURY, A. e FLEURY M.T.L. Aprendizagem e inovação organizacional: as experiências de Japão, Coréia e Brasil. São Paulo: Atlas, 1997.

. Estratégias empresariais e formação de competências: um quebra-cabeça caleidoscópico da indústria brasileira. São Paulo: Atlas, 2000.

FLEURY, M.T.L e OLIVEIRA JR., M.M. (Orgs.). Gestão estratégica do conhecimento: integrando aprendizagem, conhecimento e competências. São Paulo: Atlas, 2001.

FLEURY, M.T.L e SAMPAIO, J.R. Uma discussão sobre cultura organizacional. In: FLEURY, M.T.L. (Org.). As pessoas na organização. São Paulo: Gente, 2002.

GARVIN, D.A. Building a learning organization. Harvard Business Review. v.71, n.4, p.78-91, jul./aug. 1993.

GEUS, A. A empresa viva. São Paulo: Publifolha, 1999.

GODOY, A. S. Introdução à pesquisa qualitativa e suas possibilidades. Revista de Administração de Empresas. v.35, n.2, p.57-63, mar./abr. 1995a.

- Pesquisa qualitativa: tipos e fundamentos. Revista de Administração de Empresas. v.35, n.3, p.20-29, mai./jun. 1995b.

GOSHAL, S. e BARLETT, C. A organização individualizada: talento e atitude como vantagem competitiva. Rio de Janeiro: Campus, 2000.

JOIA, L.A. Medindo o capital intelectual. Revista de administração de empresas. São Paulo, v.41, n.2, p.54-71, abr./jun. 2001.

KERLINGER, F.N. Metodologia da pesquisa em ciências sociais: um tratamento conceitual. São Paulo: Edusp, 1980.

KIM, W.C. e MAUBORGNE, R. Fair process: managing in the knowledge economy. Harvard Business Review. v.75, n. 4, p.65-75, jul./aug. 1997.

KING, A.W., FOWLER, S.W., ZEITHAML, M.M. Competências organizacionais e vantagem competitiva: o desafio da gerência intermediária. Revista de administração de empresas. São Paulo, v.42, n.1, p.20-49, jan./mar. 2002.

LAKATOS, E.M. e MARCONI, M.A. Metodologia do trabalho científico. 4.ed. São Paulo: Atlas, 1992.

LEI, D., HITT, M.A., BETTIS, R. Competências essenciais dinâmicas mediante a metaaprendizagem e o contexto estratégico. In: FLEURY, M.T.L. e OLIVEIRA JR., 
M.M. (Orgs.). Gerenciamento estratégico do conhecimento: integrando aprendizagem, conhecimento e competências. São Paulo: Atlas, p. 158-186, 2001.

LEONARD-BARTON, D. Wellsprings of knowledge:building and sustaining the sources of inovation. Boston: Harvard Business School Press, 1995.

LEONARD-BARTON, D. e SENSIPER, S. The role of tacit knowledge in group inovation. California Management Review, v.40, n.3, p.112-131, Spring, 1998.

LINKE, J.C. A gestão do conhecimento como ferramenta de desenvolvimento das empresas da indústria moveleira da região de São Bento do Sul - SC. Dissertação (Mestrado) Florianópolis: UFSC, 2001.

MAÇADA, A.C.G. e BECKER, J.L. O impacto da tecnologia de informação na estratégia dos bancos. Revista de administração de empresas. São Paulo, v.41, n. 4, p. 87-97, out./dez. 2001.

MAXIMILIANO, A.C.A. Introdução à administração. São Paulo: Atlas, 1995.

MILKOVICH, G.T e BOUDREAU, J.W. Administração de recursos humanos. São Paulo: Atlas, 2000.

MINTZBERG, H. The nature of managerial work. Nova York: Harper e How, 1973.

. The fall and rise of strategic planning. Harvard Business Review, v. 72, n. 1, p. 107-114, Jan./Feb. 1994.

Criando organizações eficazes: estruturas em cinco configurações. São Paulo: Atlas, 1995.

MOINGEON, B. e EDMONDSON, A. Organizational learning as a source of competitive advantage. In: MOINGEON, B. e EDMONDSON, A. (Eds.). Organizational learning and competitive advantage. London: Sage, 1996.

MONTGOMERY, C. e PORTER, M.E. (Orgs.). Estratégia: a busca da vantagem competitiva. Rio de Janeiro: Campus, 1998.

MORGAN, G. Imagens da organização. São Paulo: Atlas, 1996.

NONAKA, I. The knowledge-creating company. Harvard Business Review. v.69, n.6, p.96-104, nov./dec. 1991.

NONAKA, I. e TAKEUCHI, H. Criação de conhecimento na empresa: como as empresas japonesas geram a dinâmica da inovação. 2.ed. Rio de Janeiro: Campus, 1997. 
NONAKA, I. e KONNO, N. The concept of "Ba": building a foundation for knowledge creation. California Management Review, v.40, n.3, p.40-54, Spring, 1998.

O’DELL, C. e GRAYSON, J. If only we knewwhat we know: identification and transfer of internal best practices. California Management Review, v.40, n.3, p.154-174, Spring, 1998.

OLIVEIRA, S.L. Tratado de metodologia científica. São Paulo: Pioneira, 1997.

OLIVEIRA JR., M.M. Linking strategy and the knowledge of the firm. Revista de administração de empresas. São Paulo, v.39, n.4, p.29-37, out./dez. 1999.

Competências essenciais e conhecimento na empresa. In: FLEURY, M.T.L. e OLIVEIRA JR., M.M. (Orgs.). Gerenciamento estratégico do conhecimento: integrando aprendizagem, conhecimento e competências. São Paulo: Atlas, p. 121-156, 2001.

PARKER, K.H., DE BONIS, D.F., ABUD, M.R. Introdução ao estudo da administração. São Paulo: Pinoneira, 1997.

PETTIGREW, A.M. A cultura das organizações é administrável? In: FLEURY, M.T.L, FISCHER, R.M. (Orgs.). Cultura e poder nas organizações.2.ed. São Paulo: Atlas, 1996.

PFEFFER, J. Seven practices of successful organizations. California Management Review, v. 40, n. 2, p. 96-124, Winter, 1998.

PORTER, M.E. How competitive forces shape strategy. Harvard Business Review, v. 57, n. 2, p. 146-159, Mar./Apr. 1979.

Vantagem competitiva: criando e sustentando um desempenho superior. Rio de Janeiro: Campus, 1990.

PRAHALAD, C.K. e HAMEL, G. The core competence of the corporation. Harvard Business Review, v. 68, n. 3, p. 79-91, May./Jun. 1990.

PROBST, G., RAUB, S., ROMHARDT, K. Gestão do conhecimento: os elementos construtivos do sucesso. Porto Alegre: Bookman, 2002.

QUINN, J. B., ANDERSON, P., FINKELSTEIN, S. Managing professional intellect: making the most of the best. Harvard Business Review, v. 74, n. 2, p. 71-80, mar./apr., 1996.

ROSSEAU, D. Business strategy and contracts. In: ROSSEAU, D. (Org.). Psycological contracts in organizations. Sage: Thousand Oaks, p. 180-201, 1995. 
RUAS, R. Desenvolvimento de competências gerenciais e contribuição da aprendizagem organizacional. In: FLEURY, M.T.L. e OLIVEIRA JR., M.M. (Orgs.). Gerenciamento estratégico do conhecimento: integrando aprendizagem, conhecimento e competências. São Paulo: Atlas, p. 242-269, 2001.

RUGGLES, R. The state of the notion: knowledge management in practice. California Management Review, v.40, n.3, p.80-89, Spring, 1998.

SAMMARTINO, W. A influência das políticas e práticas de gestão de recursos humanos no desempenho organizacional: um estudo de caso na área industrial de uma empresa do setor de telecomunicações. Dissertação (Mestrado) FEA-USP, São Paulo, 1995.

SAMPSON, A. O homem da companhia: uma história dos executivos. São Paulo: Companhia das Letras, 1996.

SANTOS, F.C.A. Estratégia de recursos humanos: dimensões competitivas. São Paulo: Atlas, 1999.

SANTOS, H. A bolha da vez: São Paulo é o Vale do Silício da gestão do conhecimento. Revista Exame. São Paulo, v. 36, n. 24, Suplemento Exame SP, p.21, 27/Nov./2002.

SAVAGE, C.M. $5^{a}$ geração de gerência. São Paulo: Pioneira, 1996.

SCHERMERHORN JR., J.R. Administração. 5.ed. Rio de Janeiro: LTC, 1999.

SCHNEIDER, B., GOLDSTEIN, H., SMITH, D. The ASA framework: an update. Personnel Psychology, v. 48, p. 747-773, 1995.

SCHULER, R. e JACKSON, S. Linking competitive estrategy with human resources management. Academic of Management Executive, v. 1, n. 3, p. 207-219, 1987.

SELLTIZ, C., WRIGHTSMAN, L.S., COOK, S. Métodos de pesquisa nas relações sociais. 3.ed. São Paulo: Edusp, 1974.

SENGE, P.M. A quinta disciplina: arte e prática da organização que aprende. 4. ed.ver.ampl. São Paulo: Best Seller, 1999.

SLACK, N., CHAMBERS, S., HARLARD, C. HARRISON, A., JOHNSTON, R. Administração da Produção. São Paulo: Atlas, 1996.

SPENDER, J.C. e GRANT, R.M. . Knowledge and the firm: na overview. Strategic Management Journal, v. 17, p. 5-9, 1996 (Winter Special Issue). 
SPENDER, J.C. Gerenciando sistemas de conhecimento. In: FLEURY, M.T.L. e OLIVEIRA JR., M.M. (Orgs.). Gerenciamento estratégico do conhecimento: integrando aprendizagem, conhecimento e competências. São Paulo: Atlas, 2001. p. 27-49.

SPENDOLINI, M.J. Benchmarking. São Paulo: Makron Books, 1993.

STALK, G., EVANS, P., SHULMAN, L. E. Competing on capabilities: the new rules of corporate strategy. Harvard Business Review, v. 70, n. 2, p. 57-69, mar./apr., 1992.

TAYLOR, F.W. Princípios de administração científica. São Paulo: Atlas, 1963.

TERRA, J.C.C. Gestão do conhecimento: aspectos conceituais e estudo exploratório sobre as práticas de empresas brasileira. Tese (Doutorado) Escola Politécnica, Universidade de São Paulo, 1999.

Gestão do conhecimento: aspectos conceituais e estudo exploratório sobre as práticas de empresas brasileira. In: FLEURY, M.T.L. e OLIVEIRA JR., M.M. (Orgs.). Gerenciamento estratégico do conhecimento: integrando aprendizagem, conhecimento e competências. São Paulo: Atlas, p. 212-241, 2001.

Definindo gestão do conhecimento. http://www.terraforum.com.br/lib/pages (22/Ago), 2003.

ULRICH, D. (Org.). Recursos humanos estratégicos: novas perspectivas para os profissionais de RH. São Paulo: Futura, 2000.

. Os campeões de recursos humanos: inovando para obter os melhores resultados. 7.ed. São Paulo: Futura, 2002.

. A new mandate for human resources. Harvard Business Review. v. 76, n.1, p.124-134, jan./feb., 1998.

VASCONCELOS, F.C. Da gestão do conhecimento à gestão da ignorância: uma visão co-revolucionária. Revista de administração de empresas. São Paulo, v.41, n. 4, p. 98102, out./dez. 2001.

VON KROGH, G. Care in knowledge creation. California Management Review, v.40, n.3, p.133-153, Spring, 1998.

VON KROGH, G., ICHIJO, K., NONAKA, I. Facilitanto a criação de conhecimento: reinventando a empresa com o poder da inovação contínua. Rio de Janeiro: Campus, 2001.

WERNERFELT, B. A resource-based view of the firm. Strategic Management Journal, v. 5, n. 2, p. 171-180, Apr./Jun. 1984. 
YEUNG, A. e BERMAN, B. Adding value throug human resources: reorienting human resources measurement to drive business performance. Human Resource Management, v. 36, n. 3, p. 321-335, 1997. 


\section{INTRODUÇÃO}

O mundo vem passando por uma série de mudanças históricas - políticas, econômicas e sociais - e as organizações que são sistemas abertos e têm direta relação com o ambiente externo, acabam por absorver muito destas alterações e tendo, que assim, se ajustar às novas formas com que os processos de negócio passam a ser conduzidos.

São diversos os itens sobre inovações que as organizações estão tendo que se ajustar, entre estes alguns podem ser destacados:

- o avanço das tecnologias de produção;

- $\quad$ o avanço nas tecnologias de informação;

- $\quad$ as inovações na área de telecomunicações;

- $\quad$ a globalização dos mercados;

- $\quad$ a formação de blocos econômicos;

- $\quad$ o aumento do uso da Internet;

- o aumento das exigências dos consumidores;

- a fusão de grandes organizações.

Esses e outros diversos assuntos têm traçado alterações importantes na forma com que os administradores analisam e interpretam os fenômenos organizacionais, alterando assim o comportamento das organizações e sua capacidade de resposta frente às contingências que o mercado impõe. Essa capacidade de adaptação às circunstâncias da realidade mundial e local é uma questão primordial e pode apontar a sobrevivência das organizações no processo de globalização da sociedade.

As empresas estão percebendo a necessidade de continuamente aperfeiçoarem seus produtos ou serviços, para suportar as ameaças do ambiente e superar as expectativas dos seus clientes, que atualmente têm um nível de exigência bastante 
apurado devido à grande oferta oferecida pelo mercado, que dá prioridade a produtos e serviços eficientes, que tragam soluções inovadoras, com custo acessível e que sejam providos de qualidade.

Na busca de vantagem competitiva - não só aquelas provenientes de liderança em custo, uso de tecnologia de ponta ou excelência operacional - um aspecto tem sido constantemente destacado: o conhecimento que uma organização detém. A utilização deste recurso tem se mostrado importante no combate às ameaças e maior aproveitamento das oportunidades internas e externas à organização, e como afirma Drucker (1999: XVI-XVII), é a nova fonte de riqueza para uma sociedade chamada sociedade do conhecimento.

Não se fala aqui apenas do conhecimento gerado pelos laboratórios de pesquisa e desenvolvimento, que resulta em inovações e novos produtos, mas também da grande importância do conhecimento gerado e transmitido em processos diários de trabalho por toda a organização, da linha de produção à alta administração.

Nesta questão há que se observar o aspecto relacionado às pessoas e como elas são gerenciadas nas organizações, qual a valorização que a empresa dá ao seu capital humano que é o detentor do conhecimento.

Entende-se neste trabalho o capital humano como sendo "toda capacidade, conhecimento, habilidades e experiências individuais dos empregados e gerentes” (EDVINSSON E MALONE, 1998:17).

Então, como se mostra nos próximos Capítulos, duas áreas da administração são consideradas para análise neste trabalho, a gestão do conhecimento e a gestão de pessoas.

De uma forma simples pode-se entender a gestão do conhecimento como estando “intrinsecamente ligada ao conceito de capital humano: deve ser vista como um instrumento que possibilite identificar, mapear, medir, gerenciar e, principalmente explicitar estes ativos intangíveis - talento, criatividade, intuição, capacidade de análise e contextualização - que existem na cabeça das pessoas” e que gera riqueza para as organizações (SANTOS, 2002:21).

Já a gestão de pessoas, ou gestão de recursos humanos, é vista como uma função vital dentro deste novo conceito de competitividade baseada em competências e conhecimento, assim, como se mostra neste trabalho, a gestão de pessoas é observada em três aspectos de possíveis contribuições: a criação de uma clareza estratégica dentro 
da organização, a criação e o aumento do capital humano e sendo um agente das mudanças culturais. O autor acredita que estas três proposições são importantes em iniciativas na área de gestão do conhecimento como se destaca nos Capítulos posteriores.

É dentro deste contexto que está inserido o presente trabalho, que pretende identificar as possíveis ligações existentes entre práticas e políticas de gestão de recursos humanos e iniciativas em gestão do conhecimento. O objetivo genérico do estudo é compreender como as ações enfocando a gestão de pessoal podem influenciar e facilitar as iniciativas da organização na área de gestão do conhecimento.

\subsection{Justificativa e importância do estudo}

A transição da sociedade industrial para a sociedade do conhecimento tem decorrido principalmente dos avanços tecnológicos, da globalização dos mercados e da desregulamentação das economias, tendo reflexo na organização social, política e econômica das nações e, portanto, influenciando também a gestão das empresas.

Nesta mudança pela qual o mundo vem passando, como já afirmado, o conhecimento que uma organização detém é considerado como recurso-chave.

O potencial de criação do conhecimento é inerente às pessoas que trabalham nas organizações e o uso pleno do conhecimento dos profissionais tem sido referido constantemente na literatura como fator estratégico de sucesso.

Os programas de qualidade juntamente com a propagação da experiência japonesa contribuíram para o reconhecimento da importância do fator humano no trabalho, mostrando o potencial que exerce no desempenho e na competitividade organizacionais.

Porém, com a popularização do uso de tecnologias de informação e do conceito de gestão do conhecimento as organizações precisaram ir mais além nas suas práticas e políticas de recursos humanos. Espera-se agora que esta área contribua efetivamente para o resultado dos negócios, fazendo um diagnóstico das necessidades de conhecimento da organização e aumentando a competência dos funcionários e o seu potencial de aprendizagem.

Em termos acadêmicos, este estudo será importante na medida que possa contribuir para uma melhor compreensão da teoria envolvendo gestão do conhecimento 
e gestão de recursos humanos e, em termos práticos propiciar o aperfeiçoamento do processo de planejamento dos sistemas de gestão de pessoas para organizações que pretendam atuar ativamente com práticas de gestão do conhecimento.

\subsection{Definição do problema da pesquisa}

Considerando que o objetivo genérico deste trabalho é compreender como as ações enfocando a gestão de pessoal podem influenciar e facilitar as iniciativas da organização na área de gestão do conhecimento e observando que, para Kerlinger (1980), um problema deve ser apresentado como uma pergunta na qual procura-se descobrir a relação entre duas ou mais variáveis, sendo possível testar estas relações empiricamente, formula-se o problema deste trabalho da seguinte forma:

Como as práticas e políticas relacionadas com a gestão de recursos humanos podem influenciar e facilitar os resultados esperados com a implementação de iniciativas em gestão do conhecimento?

\subsection{Objetivos}

Neste trabalho os objetivos são divididos em duas categorias: objetivo principal e objetivos secundários.

\subsubsection{Objetivo principal}

- analisar como as políticas e práticas de gestão de recursos humanos influenciam e facilitam as iniciativas na área de gestão do conhecimento.

\subsubsection{Objetivos secundários}

- caracterizar, através de revisão bibliográfica, o conceito de gestão do conhecimento e gestão de recursos humanos;

- $\quad$ estabelecer os elementos de ligação entre a gestão de recursos humanos e a gestão do conhecimento; 
- identificar os aspectos que são apontados, em um estudo de caso, como sendo impactantes na gestão de recursos humanos e na gestão do conhecimento.

\subsection{As hipóteses do trabalho}

As hipóteses que orientam este trabalho são as seguintes:

- As práticas e políticas de recursos humanos influenciam a implementação de projetos em gestão do conhecimento;

- A área de recursos humanos tem três papéis principais para contribuir com um ambiente favorável à gestão do conhecimento:

o recursos humanos atua como parceiro estratégico alinhando sua atuação com a estratégia empresarial;

o recursos humanos participa da formação das competências e comprometimento dos funcionários;

o recursos humanos é um agente da mudança cultural da organização para que as iniciativas em gestão do conhecimento tenham mais aceitabilidade.

- A área de recursos humanos deve participar ativamente das iniciativas em gestão do conhecimento.

\subsection{Organização do trabalho}

O trabalho é dividido em seis Capítulos. No Capítulo 1, faz-se uma introdução ao assunto expondo-se os objetivos e hipóteses da pesquisa.

Os Capítulos 2, 3 e 4 trazem uma contextualização teórica do tema abordado na dissertação.

O Capítulo 2 mostra a evolução ocorrida através das eras históricas da economia, abordando-se a era pré-industrial, que é seguida pela era industrial e dá bastante ênfase ao que se convencionou chamar era do conhecimento. Traz características destas eras e também procura observar algumas mudanças ocorridas com a revolução industrial e com a administração científica colocada por Taylor. 
Já o Capítulo 3 trata da gestão do conhecimento em si, trazendo os conceitos mais relevantes para o seu entendimento. Faz-se uma delimitação do assunto o qual o trabalho pretende priorizar, mostra os aspectos que diferenciam os dados, informações, conhecimento e competências. Procura-se mostrar elementos da gestão do conhecimento como: identificação, conversão, aquisição, criação e transferência do conhecimento.

O Capítulo 4 aborda a gestão de pessoas, observando-se aspectos referentes à área de recursos humanos que contribuem para uma adequada implementação das iniciativas de gestão do conhecimento e mostra a importância desta área em três frentes: (1) recursos humanos como parceiro estratégico, (2) recursos humanos na criação de capital humano e (3) recursos humanos como agente da mudança cultural.

Os Capítulos 5 e 6 trazem o estudo de caso e a conclusão do trabalho. No Capítulo 5 interpretam-se e analisam-se os dados resultantes da pesquisa empírica realizada. No Capítulo 6 realizam-se as conclusões em que se relaciona a revisão bibliográfica com os resultados da pesquisa empírica. As referências bibliográficas e os apêndices são colocados após o texto. 


\section{EVOLUÇÃO HISTÓRICA}

Este Capítulo procura mostrar uma passagem da evolução histórica em torno da qual as organizações foram se desenvolvendo. O objetivo é traçar um panorama evolutivo até a era do conhecimento, como tem sido chamado o momento atual. São abordadas algumas características gerais de cada era histórica mencionada, sem, no entanto, ter-se pretensões de levantamento histórico minucioso.

Este Capítulo divide-se em:

- $\quad$ Eras históricas da economia:

- Era pré-industrial;

- Era industrial.

- O desvendar dos mistérios dos artesãos e a Revolução Industrial;

- Taylor e a revolução da produtividade;

- $\quad$ A era e a sociedade do conhecimento.

\subsection{Eras históricas da economia}

Acredita-se que estamos vivendo uma nova era econômica baseada no conhecimento ou uma sociedade baseada no conhecimento. Antes disso, porém, a sociedade passou por alguns estágios evolutivos: da sociedade primitiva para a sociedade agrícola, desta para a sociedade industrial e passando, então, para a sociedade do conhecimento. Antes de se observar as principais características dessa sociedade do conhecimento, são mostradas algumas características das sociedades antecessoras, em especial da sociedade industrial. O Quadro 2.1 é útil para que uma caracterização maior dessas sociedades mencionadas seja visualizada. 
Quadro 2.1 Características-Chave de Quatro Sociedades Básicas.

\begin{tabular}{|c|c|c|c|c|}
\hline & Sociedade Primitiva & Sociedade Agrícola & Sociedade Industrial & Sociedade do Conhecimento \\
\hline Tecnologia & $\begin{array}{l}\text { Energia: energia humana } \\
\text { Materiais: pele de animais, pedras } \\
\text { Ferramentas: mínimas para cortar e moer } \\
\text { Cortar/moer (normalmente feitas de pedra). } \\
\text { Métodos de produção: nenhum } \\
\text { Sistema de Transporte: caminhar } \\
\text { Sistema de comunicação: vós humana }\end{array}$ & $\begin{array}{l}\text { Energia: natural (humana, animal, vento) } \\
\text { Materiais: recursos renováveis (árvores, algodão, lã) } \\
\text { Ferramentass: Força muscular humana ampliada } \\
\text { (alavancase e guinchos) ou forças naturais dirigidas } \\
\text { (navegação, roda dáagua) } \\
\text { Métodos de produção: artesanato } \\
\text { Métodos de transporte: cavalo, carroça barco a vela } \\
\text { Sistema de comunicaçăõo: manuscrito }\end{array}$ & 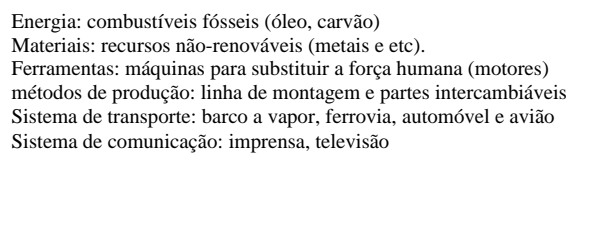 & 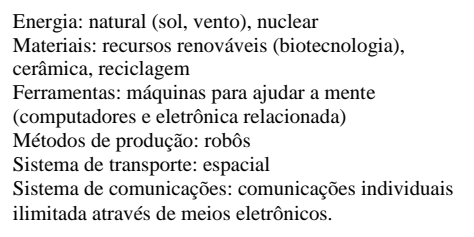 \\
\hline Economia & Coleta, caça ou pesca & $\begin{array}{l}\text { Economia local descentralizada e auto-suficiente cuja } \\
\text { atividadae econônimica central é a produçâa e o consumo de } \\
\text { alimentos, sem atividades de mercado significativas. } \\
\text { Simples divisão do trabalho em função da comunidade } \\
\text { com poucos e bens definidos níveis de autoridades } \\
\text { (nobreza, sacerdotes, guerreiros, escravosos e servos) }\end{array}$ & $\begin{array}{l}\text { Economia de mercado nacional, cuja atividade econômica é a } \\
\text { produçãa de bens padronizados, tangiviveis com divisão entre } \\
\text { produção e consumo. } \\
\text { Divisãa complexão da mão-de-obra baseada em habilidades } \\
\text { especificas, modod de trabalho padrão e organizaçōes com vários } \\
\text { niveis hierárquicos }\end{array}$ & $\begin{array}{l}\text { Economia global integrada cuja atividade econômica } \\
\text { central é a provisãa de esrviços de conhecimento } \\
\text { com maior fus̃o e entre produtor e consumidor. } \\
\text { Organizaçôes empreendedora de pequeno porte cujo } \\
\text { meio têm um ganho diretamente }\end{array}$ \\
\hline Sistema Político & $\begin{array}{l}\text { Tribo unidade política básica na qual os anciãos e } \\
\text { o chefe governam }\end{array}$ & $\begin{array}{l}\text { Feudalismo: leis, religião, classes sociais e políticos } \\
\text { atrelados ao controle das terras com autoridade } \\
\text { transmitida hereditariamente (regras aristocráticas): a } \\
\text { comunidade local é a unidade política básica. }\end{array}$ & $\begin{array}{l}\text { Capitalismo e Marxismo: leis, religião, classes sociais e políticas são } \\
\text { modelados de acordo com os interesses da propriedade e do controle } \\
\text { do investimento de capital } \\
\text { Nacionalismo: governos centralizados e fortes tanto na forma de } \\
\text { governo representativo como na forma ditatorial }\end{array}$ & $\begin{array}{l}\text { Cooperação global: instituições são modeladas com } \\
\text { base na propriedade e no controle do conhecimento } \\
\text { com organizaçôes supra nacionais/os governos } \\
\text { locais/as prinipiais unidades do governo e a } \\
\text { democracia participativa definem as normas }\end{array}$ \\
\hline Fonte de Riqueza & & A terra é o recurso fundamental & Capital físico e mão-de-obra são os recursos fundamentais & Capital humano é o recurso fundamental. \\
\hline
\end{tabular}

Fonte: Adaptado de Crawford (1993:18) 



\subsubsection{A era pré-industrial}

A economia pré-industrial, composta pelas economias primitiva e agrícola, tinha como base o extrativismo, ou seja, a extração de recursos provenientes do meio ambiente. O principal recurso que movimentou essa economia foi a propriedade da terra; era rica a pessoa que detinha a sua plantação ou mina (CRAWFORD, 1993:19).

No mesmo período em que se passava a era pré-industrial, observava-se uma variação nos sistemas de produção. Canêdo (1987:10-25) oferece uma descrição desses sistemas provenientes, sobretudo, das evoluções ocorridas no setor têxtil até o século XIX.

O sistema de produção familiar era a unidade industrial típica do artesão independente, possuidor de sua oficina e de seus utensílios de trabalho. Contava com o auxílio de aprendizes sob a direção do chefe de família. Os trabalhadores numa oficina estavam organizados de forma hierárquica, indo do aprendiz ao mestre, em vários níveis, até atingir o chefe. Todos viviam na mesma casa e participavam da vida do patrão, até adquirirem também o grau de mestre, através de um trabalho considerado de alta qualidade. Notou-se, nessa época, o surgimento das corporações de ofício ou guildas, que eram associações daqueles que se ocupavam do mesmo ofício. As guildas protegiam os conhecimentos de produção que seus associados detinham.

O comércio ampliou-se com as Grandes Navegações. Com o aumento da procura por mercadorias, os artesãos começaram a se ligar aos mercadores. Em seguida, formaram-se as manufaturas, grandes locais em que se reuniam diversos artesãos que possuíam as habilidades técnicas para produzir as mercadorias, mas a gestão era reservada ao empresário.

Um outro sistema foi o da produção domiciliar, que se caracterizava pelo fato de que o artesão trabalhava em seu domicílio, para um patrão, mediante salário, sem estar submetido a ele no que dizia respeito à direção das operações técnicas. 


\subsubsection{A era industrial}

No Quadro 2.1, pode-se notar a grande quantidade de descontinuidades ocorridas entre a era pré-industrial e a era industrial, sobretudo decorrentes da industrialização, em que novas idéias de regras e responsabilidades foram impostas deslocando os modelos feudais, inerentes ao cultivo da terra.

O início da era industrial foi marcado pela obra “A riqueza das nações”, escrito em 1776, por Adam Smith. Havia, segundo ele, havia a necessidade de se ir além do mercantilismo dos séculos XVI e XVII. Seu trabalho é bastante amplo e diversas de suas contribuições fizeram com que muitas mudanças ocorressem neste período. Ele defendia que mais riquezas poderiam ser geradas através da aplicação adequada de trabalho na manufatura, utilizando-se do princípio da divisão do trabalho (AGOSTINHO, 2002:5).

Adam Smith acreditava que a divisão do trabalho aumentaria a habilidade e destreza dos operários de mão-de-obra não especializada, visto que eles repetiriam a mesma função diariamente. Como conseqüência, perder-se-ia o contato com o processo como um todo, devido à repetição da tarefa específica. Com isso, seria eliminado o julgamento dos trabalhadores, um dos aspectos principais da sua definição de natureza do trabalho (AGOSTINHO, 2002:7).

Na era industrial, o recurso econômico principal passa de propriedade da terra para capital e mão-de-obra, a produção industrial dos produtos é a atividade principal e fundamental da economia e mais rico é aquele que detém maior volume de capital físico e financeiro (CRAWFORD, 1993:20).

\subsection{O desvendar dos mistérios dos artesãos e a Revolução Industrial}

Uma das primeiras iniciativas para que o conhecimento fosse formalizado foi a edição da Encyclopédie entre os anos de 1751 e 1772 pelos franceses Denis Diderot e Jean d'Alembert. Até então, os artesãos só passavam o conhecimento contido nos seus trabalhos, ou seja, os mistérios de como fazer as coisas, para seus aprendizes que, um dia, poderiam se tornar artesãos. Com a Encyclopédie, os autores conseguiram organizar e sistematizar o conhecimento de diversas profissões 
artesanais, de modo que um não-aprendiz pudesse vir a aprender como se tornar um artesão. Contaram com o apoio de pessoas como Voltaire e Rosseau, que contribuíram com artigos, agindo como especialistas em informação, observando os artesãos realizarem seus trabalhos para, depois, transferi-los para o livro (DRUCKER, 1999:13).

Segundo Canêdo (1987:13), a Encyclopédie foi a obra científica mais importante do século XVIII, fazendo um balanço dos conhecimentos técnicos acumulados pela humanidade.

Nesse mesmo período, surgiu uma grande invenção que faria com que o mundo passasse por uma das fases mais importantes da História. James Watt inventou o motor a vapor, dando origem ao que passou a se chamar revolução industrial.

Drucker (1999: 7-8) faz uma interessante análise de como o motor a vapor mudou a história do mundo e das organizações. Entre 1765 e 1776, James Watt reprojetou o motor a vapor, focalizado por toda sua vida para um único uso: bombear água para fora de uma mina. Em seguida, o motor a vapor foi usado para bombear ar para dentro de um alto-forno; anos depois já estava sendo usado para diversos tipos de processos industriais, em especial para a indústria têxtil. Logo surgiu o barco a vapor e, em seguida, a locomotiva.

Sem dúvida, o reprojeto do motor a vapor por James Watt foi um marco para as mudanças que o mundo e a sociedade vieram a sofrer, porém Drucker (1999:14) atribui os créditos da revolução industrial à Encyclopédie e às escolas técnicas do século XVIII, que, apesar de não abordarem a criação de novos conhecimentos relacionados a ferramentas, processos e produtos, conseguiram sistematizar o conhecimento até então existente.

"Elas (as escolas técnicas e a Encyclopédie) reuniram, codificaram e publicaram a téchne*, o mistério do artesanato, como havia sido desenvolvido ao longo de milênios. Elas converteram experiência em conhecimento, aprendizado em livro-texto, segredo em metodologia, fazer em

\footnotetext{
* A palavra téchne é de origem grega e significa o mistério de uma habilidade, por volta de 1700 passou-se a utilizar a palavra tecnologia composta por téchne associada à palavra logia que significa conhecimento sistematizado, organizado e significativo.
} 
conhecimento. Esses são os fatores essenciais daquilo que chamamos de 'Revolução Industrial' - a transformação, pela tecnologia, da sociedade e da civilização do mundo inteiro" (DRUCKER, 1999:14).

Segundo Agostinho (2002:9), por volta de 1880, o tamanho, a complexidade e a extensão geográfica das corporações que provinham do início da era industrial começaram a provocar o aparecimento de novas necessidades. As empresas passaram a ter hierarquias definidas e muito bem escalonadas. Observa-se que, aliado à divisão do trabalho, houve a divisão do gerenciamento, a separação entre proprietário e administrador e a separação entre pensar e fazer. Esse último assunto, a separação entre pensar e fazer, é o próximo tópico abordado.

\subsection{Taylor e a revolução da produtividade}

Uma das primeiras contribuições para a teoria da administração foi a obra de Frederick Winslow Taylor, "Princípios da administração científica” em 1911 (TAYLOR,1963), sem dúvida, passados alguns anos, a administração científica de Taylor, fez com que diversas outras teorias de administração surgissem, muitas, como é sabido, surgiram para se contrapor ao que Taylor pregava.

É natural que de uma idéia derivem outras, como afirma Crawford (1993:16), os historiadores econômicos desenvolveram um modelo para entender a evolução sofrida na economia e na sociedade nos últimos 250 anos, o modelo diz que novos conhecimentos levam a novas tecnologias, que geram mudanças econômicas, que por sua vez acarretam mudanças sociais e políticas que conduzem a uma nova visão do mundo.

Taylor contribuiu significativamente para a evolução do pensamento administrativo, fazendo com que novas idéias e preceitos fossem destacados a partir dos seus princípios. Este item do trabalho procura trazer uma abordagem da contribuição de Taylor observada por diversos autores, procurando mais a sua contribuição em termos de como ele influenciou as organizações, da sua época aos dias atuais. 
O destaque dado a alguns aspectos dos princípios defendidos por Taylor tem o intuito de mostrar algumas abordagens dadas ao conhecimento em outras épocas, já destacado neste trabalho, como por exemplo, a edição da Encyclopédie. Acredita-se que fatos como esse trouxeram impacto em pontos que são, mais adiante, defendidos, sem pretensão de defender uma corrente teórica específica.

Drucker (1999:18) expõe que a principal motivação de Taylor para desenvolver o estudo do trabalho (uma das técnicas da administração científica, composta pelo estudo do método e da medição do trabalho) foi a sua indignação perante a falta de entendimento entre os proprietários e os trabalhadores. Procurou desenvolver métodos para que os trabalhadores pudessem ser mais produtivos, e com isso, receber mais pela produção alcançada, ter salários melhores. Até a sua morte, sempre procurou deixar claro que os principais beneficiários da produtividade deveriam ser os trabalhadores e não o patrão. Queria ver uma sociedade em que houvesse interesse comum pela produtividade, com relacionamento harmonioso entre as partes, através da aplicação do conhecimento ao trabalho.

“As pessoas que chegaram mais perto de entender isso até hoje foram os empregados e os líderes sindicais do Japão pós Segunda Guerra Mundial” (DRUCKER, 1999:18).

Sampson (1996:59-60), contextualiza a administração científica à sua época, porém, coloca a sua visão, procurando fazer justiça a Taylor:

“Na verdade, Taylor era muito mais humano que a maioria dos donos de fábricas e preocupava-se muito com a harmonia no local de trabalho, tal como os industriais japoneses que vieram depois. Em sua obra clássica Principles of scientific management (Princípios da administração científica), publicada em 1911, ele argumentava que trabalhadores e patrões deveriam ter responsabilidades mais iguais e que os operários deveriam ser estimulados a sugerir melhorias - o que hoje parece muito japonês. Insistia que os gerentes - uma palavra de que não gostava - deveriam estudar as características dos trabalhadores e ajudá-los a progredir, e se tornarem servidores dele, não seus senhores”. 
Situando a importância da contribuição de Taylor, Drucker relata:

“Quando o conhecimento mudou de significado há duzentos e cinqüenta anos, ele começou a ser aplicado a ferramentas, processos e produtos. Esse ainda é o significado da tecnologia para a maioria das pessoas e também o que está sendo ensinado nas escolas de engenharia. Mas dois anos antes da morte de Marx já havia começado a revolução da produtividade. Em 1881, um americano, Frederick Winslow Taylor (1856-1915), pela primeira vez aplicou o conhecimento ao estudo do trabalho, a sua análise e a sua engenharia” (DRUCKER, 1999:18).

Fortalecendo o pensamento de Drucker, Parker et al. (1997:27) afirmam que Taylor "representou um marco crucial na evolução das idéias sobre produção, riqueza e relações harmônicas entre empregados e empregadores. Foi o iniciador do estudo da eficiência industrial e, dessa forma, contribuiu para o desenvolvimento empresarial do século XX”.

Taylor acreditava que cada tarefa poderia ser cientificamente estudada chegando a uma forma única e correta de ser feita. Agostinho (2002:13) destaca que “o axioma de Taylor, pelo qual todo trabalho manual podia ser analisado e organizado pela aplicação do conhecimento, era um absurdo para seus contemporâneos”.

A especialização das tarefas, grande preocupação de Taylor, e seu princípio de treinamento intenso, fizeram com que operários desqualificados se tornassem, no prazo de sessenta a noventa dias, soldadores e construtores de navios de primeira classe. À época da Segunda Guerra, as técnicas de Taylor foram imprescindíveis para treinar operários em diversos ramos da indústria, em linhas de montagens, chegando até a produzir instrumentos óticos de precisão, este fato foi ponto marcante na vitória americana frente aos japoneses e alemães (DRUCKER: 1999, 17-24).

Uma outra questão colocada junto aos princípios da administração científica era a distinção entre pensar e fazer, fruto da alta especialização nas tarefas que Taylor desejava; Morgan (1996:32), ao se referir ao tema afirma que Taylor pregava que: "os gerentes devem pensar a respeito de tudo o que se relaciona com o 
planejamento e a organização do trabalho, deixando aos trabalhadores a tarefa de implementar isso na prática”.

Além da separação entre pensar e fazer, a administração científica contava com os seguintes princípios (SLACK et al., 1996: 292-293):

- o trabalho deve ser investigado de forma científica, com a finalidade de se estabelecerem leis e regras para determinar a melhor maneira de se executar uma tarefa, assim se estabeleceria 'o trabalho justo de um dia';

- para que os trabalhadores conseguissem realizar suas tarefas de forma mais produtiva, eles devem ser cientificamente selecionados, treinados e desenvolvidos com metodologia;

- deve haver um ambiente de cooperação entre empregadores e trabalhadores, visando benefícios comuns às duas partes.

Nonaka e Takeuchi (1997:40-41) viram, como Drucker, a forma inovadora de tratamento dado ao conhecimento por Taylor: “A ‘administração científica’ foi uma tentativa de formalizar as experiências e habilidades tácitas dos trabalhadores em conhecimento científico e objetivo". Criticam Taylor, ao qual faltou "encarar as experiências e julgamentos dos trabalhadores como uma fonte de novos conhecimentos”, ficando a criação de novos métodos de trabalho apenas a cargo da gerência.

Morgan (1996:32) faz críticas veementes à forma em que Taylor colocou a administração científica, porém não deixa de aceitar a sua influência até os dias de hoje:

“Taylor foi um engenheiro mecânico e um extravagante, ou então alguém com uma personalidade que pode ser considerada, de alguma forma, perturbada. Na época de sua morte em 1915 havia ganho a reputação de 'o maior inimigo do trabalhador', tendo sido convocado em 1911 para defender o seu sistema de administração perante um comitê da Casa dos Representantes dos EUA. Embora seja um dos autores mais perniciosos e criticados de todos os teóricos organizacionais, comprovou também ser um dos mais influentes. Os princípios de sua administração científica ofereceram 
a base para o modo de trabalhar por toda a primeira metade deste século $e$, em muitas situações, predominam até os dias de hoje”.

Drucker (1999:22) acredita que a aplicação do conhecimento ao trabalho, feita por Taylor, foi capaz de aumentar a produtividade das organizações de forma impressionante, afirmando que as máquinas haviam criado mais capacidade produtiva, porém os trabalhadores eram tão produtivos quanto os trabalhadores da Grécia antiga.

Nem tudo aconteceu conforme as idéias iniciais que Taylor pregou, pelo contrário, muitos patrões usaram seus princípios e benefícios alcançados com o aumento da produtividade exclusivamente para seus próprios ganhos, e não dos trabalhadores. Os gerentes não se tornaram servidores dos operários, usavam as recomendações de Taylor como forma de aumentar o seu status e poder, usando mais arbitrariedade. Taylor ficou inevitavelmente associado à mecanização do homem (SAMPSON, 1996:60).

A contribuição de Taylor e seus seguidores é destacada por Spender (2001:31) como precursora do interesse atual em gestão do conhecimento. Ele afirma que: "Taylor e seus colegas viram que a estrutura da organização e seus padrões de autoridade e controle exerciam impacto significativo sobre o incentivo para a criação e compartilhamento do conhecimento", pilares essenciais das iniciativas em gerir conhecimento.

\subsection{A era e a sociedade do conhecimento}

Observou-se a transição de uma sociedade pré-industrial - a sociedade primitiva e em seguida a sociedade agrícola - para a sociedade industrial. Nesta, um grande número de mudanças e paradigmas foi observado e, a riqueza principal passou, primeiramente, da terra para o capital e mão-de-obra.

A automação substituiu em muito a força física do trabalho no processo produtivo, a economia está cada vez mais globalizada. A tecnologia, os meios eletrônicos e as telecomunicações vêm mudando muito as formas de comunicação e 
o acesso às informações. Há uma alta exigência dos consumidores ao adquirirem produtos e serviços.

Percebe-se que uma nova era pode estar surgindo, o que muitos estão chamando de era do conhecimento ou sociedade do conhecimento. A seguir, é oferecida uma fundamentação de alguns autores sobre este conceito, bem como as suas características fundamentais (Quadro 2.1).

Segundo Drucker (1999: XVI-XVII), o mundo está vivendo uma era intitulada por ele de sociedade do conhecimento, na qual as figuras principais são os trabalhadores do conhecimento, ou seja, "pessoas que sabem alocar conhecimento para uso produtivo, assim como os capitalistas sabiam alocar capital para isso”, destacando o valor do conhecimento como recurso chave:

“O recurso econômico básico - 'os meios de produção', para usar uma expressão dos economistas - não é o capital, nem os recursos naturais (a 'terra' dos economistas), nem a mão-de-obra. Ele é e será o conhecimento. As atividades centrais de criação de riqueza não serão nem a alocação de capital para usos produtivos nem a mão-de-obra - os dois pólos da teoria econômica dos séculos dezenove e vinte, seja ela clássica, marxista, keynesiana ou neoclássica. Hoje o valor é criado pela 'produtividade' e pela ‘inovação', que são aplicações do conhecimento ao trabalho”.

Nonaka e Takeuchi (1997:51) acreditam ter sido Drucker um dos primeiros teóricos da administração a notar a transformação e o propor o termo sociedade do conhecimento e trabalhadores do conhecimento, por volta de 1960.

"Se antes o que gerava riqueza e poder era o domínio do capital, da terra e do trabalho, hoje a realidade é outra” (Cavalcanti et al., 2001:21). Escreve-se esta afirmação baseados em dados da OCDE - Organização para a Cooperação e Desenvolvimento Econômico - de 1999 em que destacam que mais de 55\% da riqueza mundial é originada a partir da aplicação de conhecimento a bens e produtos intangíveis “softwares, patentes, royalties, serviços de consultoria e bens culturais”. 
A transição de uma sociedade industrial para uma sociedade, em que o principal fator de riqueza passa a ser o conhecimento, também é entendida por Crawford (1993:29) que aborda algumas características dessa mudança:

- crescente automação do trabalho, de manufatura a serviços;

- aumento na indústria de serviços, sobretudo em saúde, educação e softwares;

- aumento de pequenas e médias empresas;

- $\quad$ envelhecimento da população;

- destaque para a pesquisa e educação, com centro geográfico em informações e conhecimento.

Thurow* (apud ANTUNES, 1999:29), concordando em alguns pontos com Crawford, acrescenta outros aspectos para explicar essa transição. Apresenta:

- o fim do comunismo, liberando terra e pessoas para se juntar ao capitalismo;

- a mudança tecnológica faz com que o conhecimento seja a única fonte de vantagem competitiva sustentável;

- mudança demográfica: o envelhecimento da população;

- globalização da economia, influenciada pela tecnologia, meios de transporte e telecomunicações.

O Quadro 2.2 auxilia no entendimento da transição da sociedade industrial para a sociedade do conhecimento, considerando, principalmente, a mudança na alocação da força de trabalho, com destaque para amplitude alcançada no setor de serviços, ocorrida, acredita-se, como decorrência do aumento da automação da manufatura.

\footnotetext{
* THUROW, C.L. O futuro do capitalismo. Rio de Janeiro: Rocco, 1997 apud ANTUNES, M.T.P. Contribuição ao entendimento e mensuração do capital intelectual. Dissertação (Mestrado). São Paulo: Faculdade de Economia, Administração e Contabilidade FEA-USP, 1999.
} 
Quadro 2.2 - Alocação da Força de Trabalho nas eras Econômicas.

\section{Economia Agrícola}
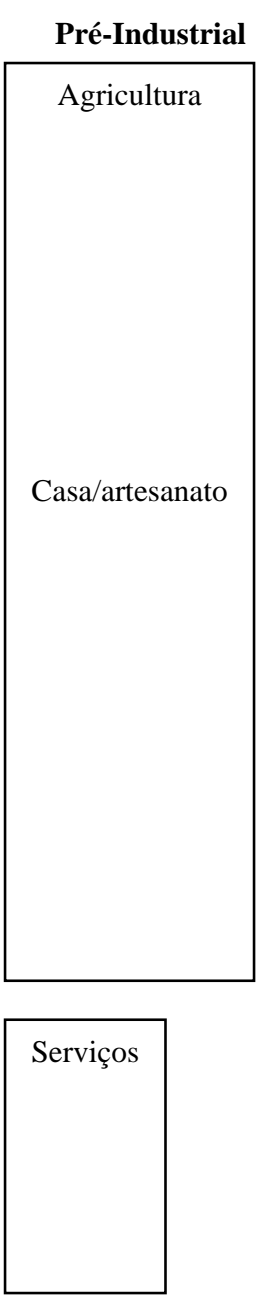

Fonte: Crawford (1993:26)

\section{Economia Industrial}
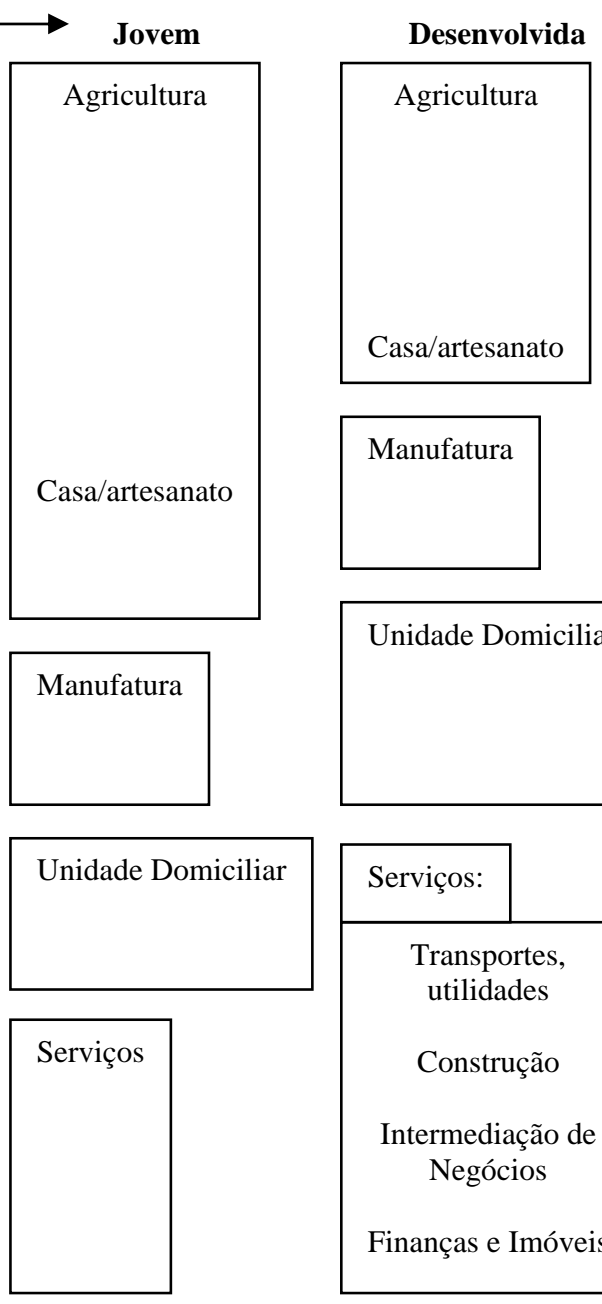

Unidade Domiciliar

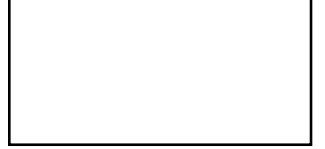

\begin{tabular}{|c|}
\hline Serviços: \\
\hline Transportes, \\
utilidades \\
Construção \\
Intermediação de \\
Negócios \\
Finanças e Imóveis \\
\hline
\end{tabular}

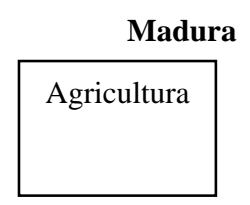

Manufatura
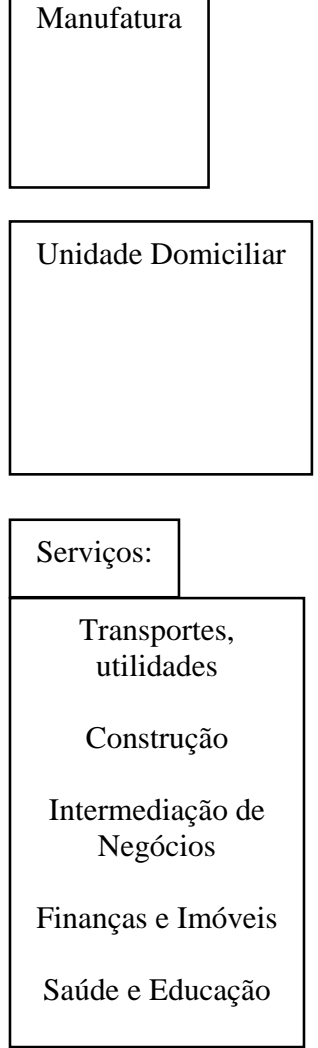

\section{Sociedade Baseada em Conhecimentos}

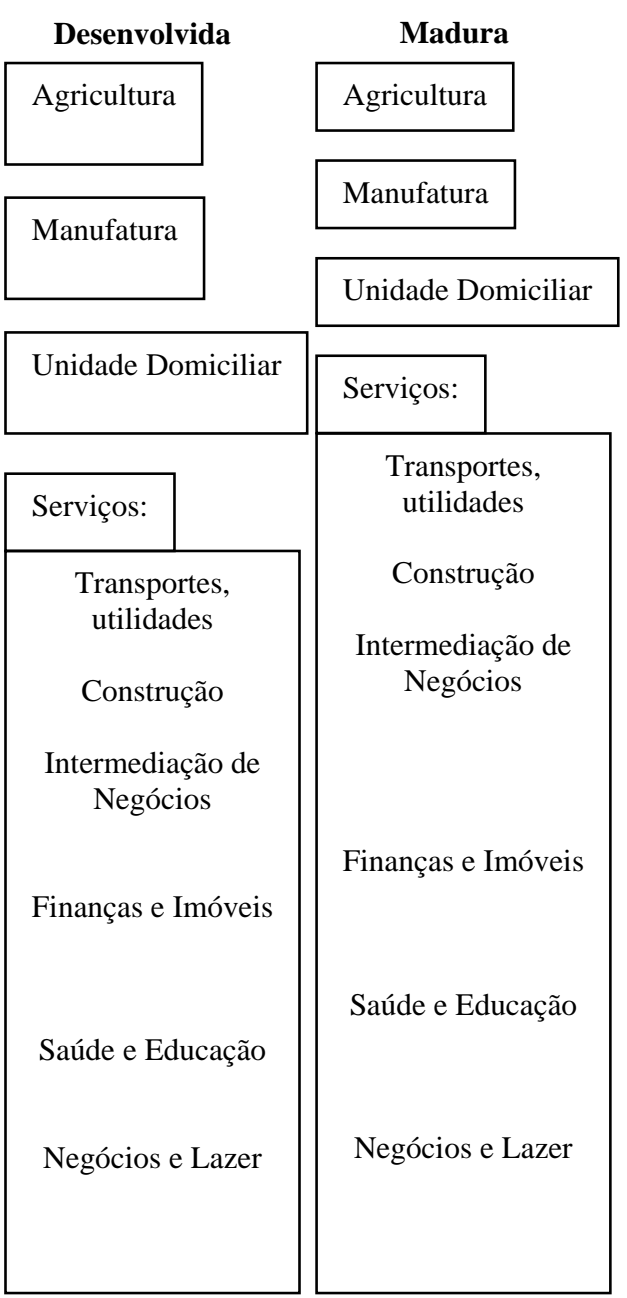


Em outras partes deste trabalho, o tema sobre sociedade do conhecimento ou era do conhecimento é retomado. O propósito desta passagem histórica é contextualizar a importância hoje dada ao conhecimento como recurso-chave nas organizações.

É importante destacar que o autor concorda com as proposições de que o mundo atualmente vive uma fase de transição para uma era em que os recursos produtos e serviços - provenientes da aplicação do conhecimento ao trabalho são o diferencial competitivo.

Em outros momentos do trabalho, é enfatizado o tratamento dado ao conhecimento como recurso competitivo, considerando outras implicações que são relacionadas oportunamente. 


\section{GESTÃO DO CONHECIMENTO}

Conhecimento, bem como a iniciativa de tentar geri-lo, são, sem dúvida, assuntos que poderiam ocupar páginas e páginas de qualquer trabalho que tentasse defini-los. Nesta dissertação, procura-se observar o conhecimento e a gestão do conhecimento como instrumentos que podem levar uma organização a atingir uma vantagem competitiva e, sobretudo, uma vantagem competitiva sustentável. No Capítulo 4, observa-se a gestão de pessoas dentro desse contexto de competitividade; no presente Capítulo a gestão do conhecimento recebe o mesmo tratamento.

É dada atenção aos aspectos conceituais referentes à gestão do conhecimento, cujo objetivo é chegar a uma síntese dos principais pontos que têm utilidade neste trabalho. O tema gestão do conhecimento tem sido muito explorado e discutido atualmente, tanto no meio acadêmico como no empresarial, o que deixa mais difícil, pelo excesso de dados, a intenção de tornar o estudo abrangente. Desta forma, o Capítulo começa com uma delimitação do que se pretende trabalhar, especificamente, dentro do assunto e, a partir de então, inicia-se uma busca conceitual para que haja conexão entre gestão do conhecimento e os demais Capítulos.

O Capítulo é organizado da seguinte forma:

3.1 Gestão do conhecimento: uma delimitação;

3.2 Dados, informações e conhecimento;

3.3 Conhecimento e competências: o capital humano;

3.4 Elementos da gestão do conhecimento;

3.4.1 Codificação e transferência do conhecimento;

3.4.2 Identificação do conhecimento;

3.4.3 Aquisição de conhecimento;

3.4.4 Criação de conhecimento e suas condições capacitantes. 


\subsection{Gestão do conhecimento: uma delimitação}

No Capítulo 2, foi mostrada uma evolução histórica na sociedade e na economia, desencadeando uma série de mudanças que também afetaram o ambiente organizacional. O mundo saiu de uma era primitiva, para uma era industrial e chegou ao que hoje se chama de era do conhecimento.

A gestão do conhecimento tem sido, nos anos 90 e atualmente, tema de exaustivos estudos na literatura sobre administração de empresas. Diversos artigos e livros existem nesta área, as consultorias têm grande procura para os seus serviços nesta área (NONAKA e KONNO, 1998:40; SPENDER, 2001:27; VON KROGH et al. 2001:11); dessa forma, existe uma relativa dificuldade em separar trabalhos que realmente trazem alguma contribuição, daqueles que apenas querem repassar o tema.

A definição oferecida por Terra (2003), de gestão do conhecimento, mostra o entendimento que o trabalho dá ao tema:

“Gestão do conhecimento significa organizar as principais políticas, processos e ferramentas gerenciais e tecnológicas à luz de uma melhor compreensão dos processos de geração, identificação, validação, disseminação, compartilhamento e uso de conhecimentos estratégicos para gerar resultados para a empresa e benefícios para seus colaboradores".

Dentro do emaranhado de questões que envolvem e podem envolver a gestão do conhecimento, por se tratar de um assunto polêmico e de difícil entendimento, como sugere Fleury e Oliveira Júnior (2001:15), procura-se, neste trabalho, buscar uma linha em que haja relação entre o tema e a gestão de pessoas na busca da vantagem competitiva, passando-se abaixo, uma contextualização de que rumo dentro da gestão do conhecimento o trabalho segue.

Barclay e Murray (2002) observaram a amplitude do tema e procuraram estabelecer três distinções importantes à gestão do conhecimento. Classificaram estas abordagens como: abordagem mecanicista, abordagem cultural/comportamental e abordagem sistemática. Abaixo, segue um detalhamento das três abordagens. 
Na abordagem mecanicista, existe uma maior preocupação com o uso de ferramentas de tecnologia da informação na gestão do conhecimento, cujas principais características são:

- a chave está na acessibilidade da informação, sua reutilização e documentação (banco de dados, hipertexto, etc.);

- $\quad$ as soluções-chave são encontradas em tecnologia de network, especialmente Intranet e Groupware.

Esta abordagem é de fácil implementação, as tecnologias são de fácil acesso, permitem rápida familiarização pelas pessoas e, segundo os autores, pode trazer uma melhora importante, por tornar acessível alguns ativos intelectuais da organização. Porém, do médio ao longo prazo, tende a gerar um número grande de informações e dificuldade de relacionar os resultados com a performance da empresa.

A abordagem cultural/comportamental tem suas origens principalmente nos programas de reengenharia dos processos e gestão de mudanças, tende para uma visão gerencial do "problema do conhecimento" e, concentra mais recurso na inovação e na criatividade, ou seja, nas “organizações que aprendem”, do que no uso do conhecimento existente ou na sua explicitação. Suas principais características são:

- mudança dramática na cultura e no comportamento organizacionais para atendimento de um maior número de informações;

- considerações que só a tecnologia é incapaz de resolver o "problema do conhecimento”, invocando a necessidade de uma visão holística da cultura e do comportamento organizacionais. O foco é no processo e não na tecnologia;

- destaque da importância dos gerentes em todos os níveis para que haja sucesso na iniciativa.

A abordagem sistemática à gestão do conhecimento considera que é necessária uma nova forma, para se entender o "problema do conhecimento" e acredita em uma visão racional. Suas principais características são:

- dá importância aos resultados sustentáveis, não ao processo ou à tecnologia; 
- acredita que um recurso para ser utilizado deve ser modelado, percebe que muitos aspectos do conhecimento corporativo podem ser modelados como recursos explícitos;

- vê a gestão do conhecimento como um matéria interdisciplinar e dá importância ao exame da natureza do trabalho e do conhecimento;

- dá importância ao comportamento e cultura organizacionais sem, entretanto, pregar uma mudança dramática nas pessoas. A tecnologia pode ser aplicada para gestão do conhecimento;

- dá a devida importância aos gerentes, porém estes não são os únicos responsáveis pelo sucesso da iniciativa de gestão do conhecimento.

Colocadas estas três abordagens - mecanicista, cultural/comportamental e sistemática - tem-se aberta uma ampla janela para observação do tema. Embora o estudo de caso realizado tenha grande ligação com tecnologia, para este trabalho, é considerado um misto entre a abordagem cultural/comportamental com a abordagem sistemática, acreditando-se em dois aspectos importantes para tratar o tema: tecnologia e pessoas.

Quanto à tecnologia, na época atual é desnecessário afirmar que sua importância é de grande destaque, as ferramentas em tecnologia da informação capacitam uma organização a operar sistemas de gestão do conhecimento capturando e fornecendo dados e informações internos e externos à organização. Um grande recurso computacional, que tem muita contribuição em programas de gestão do conhecimento, são as redes de computadores. Através de recursos como correio eletrônico, Internet, Intranet e outros, pessoas podem se comunicar e trocar conhecimentos sem ter dependência de sua localização. Porém a tecnologia da informação não cria novo conhecimento, nem é garantia de que o conhecimento seja devidamente compartilhado.

Há que se destacar que os inúmeros exemplos de diversas corporações que fazem uso intensivo de tecnologia de informação têm mostrado resultados muito positivos. Recursos de vídeo e teleconferência, soluções clássicas de groupware, como o Lotus Notes, ajudam a difundir o conhecimento por toda a empresa. Sistemas tridimensionais de projeto auxiliado por computador e manufatura auxiliada por computador, ajudam no desenvolvimento de novos produtos e protótipos (VON KROGH, 2001:39). 
Neste trabalho, são abordados alguns aspectos gerais sobre algumas iniciativas em tecnologia de informação para a gestão do conhecimento, sem, no entanto, querer chegar a um ponto exploratório abrangente, visto que isso seria muito difícil dada a dinamicidade com que novos produtos neste segmento chegam ao mercado. São destacados alguns aspectos que a literatura de gestão tem considerado importante em relação ao assunto.

Como afirmam Davenport e Prusak (1998:171):

“A tecnologia isoladamente não fará com que uma pessoa possuidora do conhecimento o compartilhe com as outras. A tecnologia isoladamente não levará o funcionário desinteressado em buscar conhecimento a sentar diante do teclado e começar a pesquisar. A mera presença da tecnologia não criará uma organização de aprendizado contínuo, uma meritocracia nem uma empresa criadora do conhecimento".

Desta forma, o trabalho dá maior ênfase aos esforços relacionados com as pessoas dentro da organização para tratar o assunto gestão do conhecimento, ou seja, um foco maior nas questões culturais e comportamentais da organização que possam capacitá-la para obter retorno com o uso adequado do conhecimento, dando importância, também, aos conceitos relacionados com a aprendizagem organizacional.

Concorda-se, então, com as afirmações de Fleury e Oliveira Júnior (2001:16) que consideram a gestão do conhecimento um tema intrínseco à aprendizagem organizacional e à gestão da tecnologia:

“... não é adequado pensar a gestão de conhecimento com um tema essencialmente novo em administração de empresas, mas como um tema que deve ser entendido como desdobramento e aprofundamento de linhas teóricas que vêm sendo desenvolvidas há mais tempo, notadamente pelos estudiosos da aprendizagem organizacional; é também fortemente influenciado pelos temas da gestão tecnológica e pelos estudos de cognição empresarial”.

Neste trabalho, a gestão do conhecimento é tratada de uma forma não exclusivamente tecnológica, sem é claro, deixar de considerar essas importantes 
ferramentas. Porém, o trabalho tem como objetivo colocar a gestão do conhecimento como um ponto de apoio para que a empresa consiga obter e sustentar a sua vantagem competitiva. Entende-se a gestão do conhecimento como uma possibilidade de integração entre os conhecimentos tácito e explícito que, quando compartilhados e transformados, podem possibilitar um aprendizado organizacional. O intuito desse aprendizado, que deve ser constante, é fazer com que a organização desenvolva capacidades organizacionais que levem seus processos e produtos/serviços a serem continuamente questionados, considerando-se as escolhas estratégicas que a organização tem de fazer.

Neste entendimento dado à gestão do conhecimento, é importante uma integração entre a aprendizagem organizacional e os conceitos de competências ou capacidades organizacionais. Um dos pontos que a gestão do conhecimento pode ajudar é sistematização do que a empresa já sabe, ou seja, tornar propícia a troca de conhecimentos e a interação desses conhecimentos, gerando conhecimentos novos em processos e sistemas gerenciais e inovação para novos produtos e serviços. O conhecimento é, neste caso, visto como um ativo essencial da organização. Essa abordagem também pretende suprir as lacunas de conhecimento ou competência que a empresa tem e estabelecer metas de conhecimentos ou competências a ser desenvolvidos. A Figura 3.1 ajuda a entender a dimensão desejada para a gestão do conhecimento.

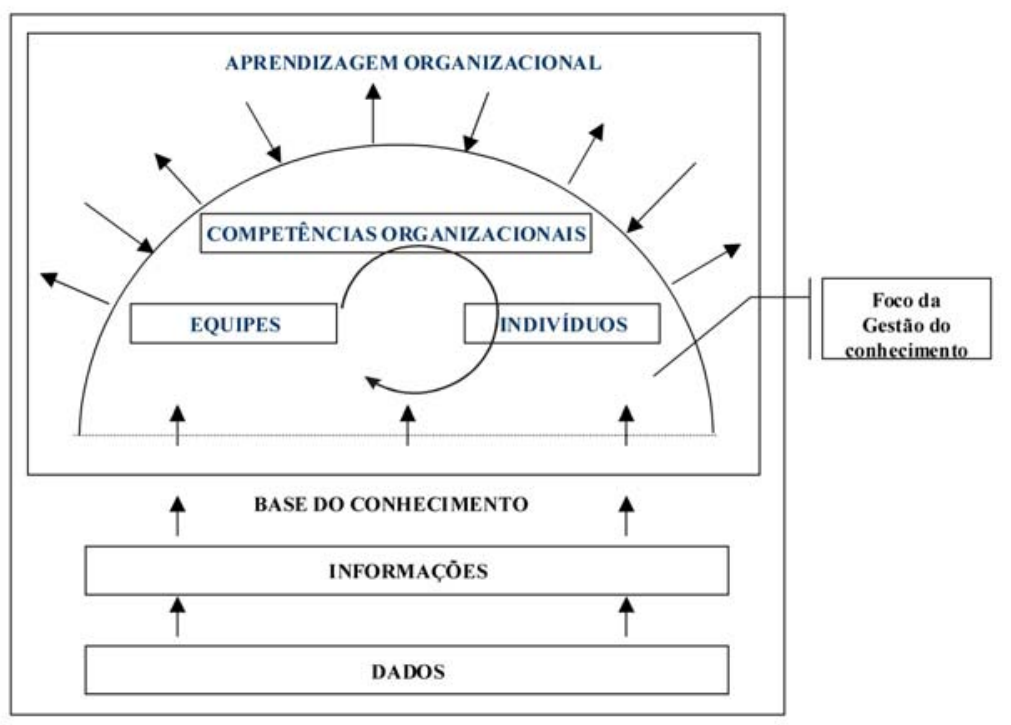

Figura 3.1 - Componentes da Gestão do Conhecimento. Adaptado de Probst et al. (2002:22) 
Um dos pontos primordiais do trabalho é entender a gestão do conhecimento do aspecto humano, ou seja, como a contribuição do indivíduo e do grupo que ele ajuda a formar são imprescindíveis para o sucesso dessas iniciativas, isto gera a necessidade de envolver o assunto com outros temas, como por exemplo, cultura organizacional, que pode oferecer condições ambientais para uma efetiva gestão do conhecimento.

São considerados como aspectos de grande relevância, nos esforços para gestão do conhecimento, a visão e a missão da empresa, bem como o envolvimento da alta organização, destacado em diversas partes deste trabalho.

A definição de gestão do conhecimento, abaixo citada, contribui para o esclarecimento do tema:

“Em suma, a gestão do conhecimento está imbricada nos processos de aprendizagem nas organizações e, assim, na conjunção desses três processos: aquisição e desenvolvimento de conhecimentos, disseminação e construção de memórias, em um processo coletivo de elaboração das competências necessárias à organização” (FLEURY e FLEURY, 2000:33).

Complementando o entendimento sugerido em que há direta relação entre a gestão do conhecimento e a aprendizagem organizacional, acredita-se ser corroborativa a definição dada por Garvin (1993:80):

“A organização que aprende é a que dispõe de habilidades para criar, adquirir e transferir conhecimentos, e é capaz de modificar seu comportamento, de modo a refletir os novos conhecimentos e idéias”.

Para que este entendimento da gestão do conhecimento seja atingido, os próximos tópicos do trabalho abordam a questão dos dados, informações, conhecimentos e competências no ambiente organizacional.

\subsection{Dados, informações e conhecimento}

Para uma correta contextualização da problemática a ser estudada, faz-se necessária uma diferenciação dos aspectos conceituais de dados, informações e 
conhecimento, para que, nas próximas etapas do trabalho sejam compreendidos outros conceitos, como o de competências organizacionais.

Num primeiro instante, é importante destacar que não se busca um entendimento filosófico para a questão do conhecimento, mas elementos úteis para entendê-lo no ambiente empresarial. Por acreditar que dados e informações são componentes do conhecimento, entende-se que estas definições prévias são importantes. Outros autores, como citam Davenport e Prusak (1998:2), consideram outros componentes como sabedoria, insight, determinação e ação, porém, nesta dissertação, são considerados os três aspectos já citados, por entender-se que são suficientes para que o contexto desejado seja explicitado.

Na Figura 3.2 apresenta-se uma ilustração dos conceitos que estão sendo abordados, na qual observa-se que, a partir de símbolos chega-se ao conhecimento.

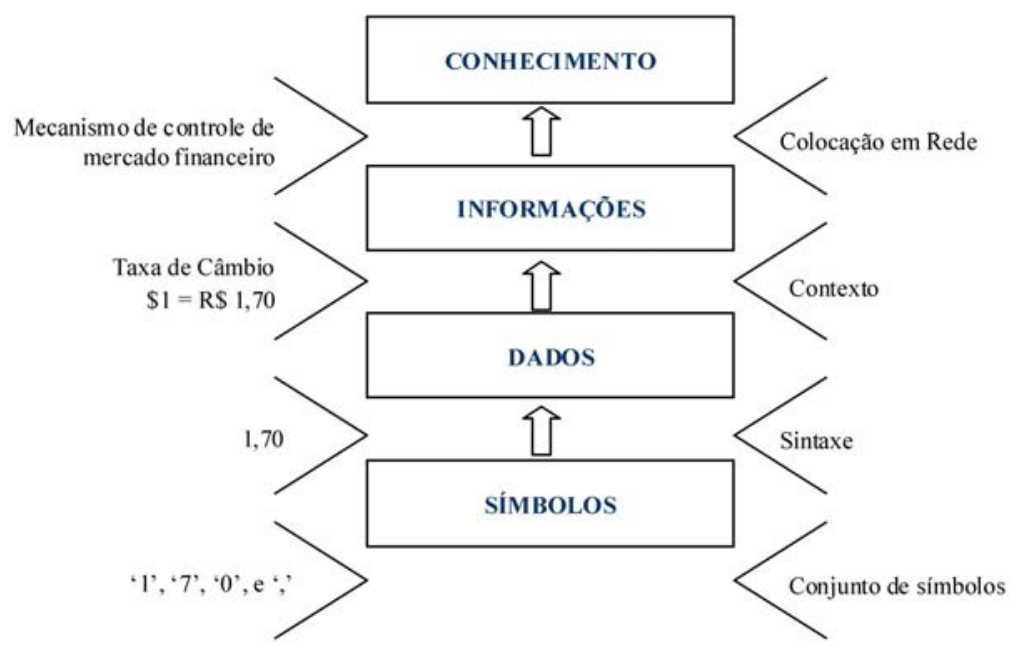

Figura 3.2 Dos Símbolos ao Conhecimento. Adaptado de Probst et al. (2002:22).

"Quando as regras de sintaxe são aplicadas aos símbolos, eles se tornam dados. Os dados são passíveis de interpretação dentro de um contexto específico, fornecendo, desta forma, informações ao receptor” (PROBST et al., 2002:23).

No contexto organizacional, segundo Davenport e Prusak (1998:2), “dados são um conjunto de fatos distintos e objetivos, relativos a eventos”. Os dados são os registros das transações: a quantidade de itens que um cliente comprou são dados que, registrados corretamente, têm utilidade na organização. Esses dados não são estruturados, portanto, não consideram o contexto em que estão inseridos, ou seja, não 
mostram porque o cliente procurou aquele local e não outro, nem porque comprou algumas unidades no lugar de uma apenas.

As organizações têm se preocupado, há algum tempo, em armazenar adequadamente os seus dados, que, em um panorama geral, trazem grandes benefícios a determinados segmentos empresarias como bancos, seguradoras e serviços públicos, entre outros. Até recentemente muitas empresas tinham o seu centro de processamento de dados, os CPDs. A tendência perseguida atualmente é uma descentralização dos bancos de dados, disponibilizando-os diretamente no computador pessoal de quem deseja obtê-lo (DAVENPORT e PRUSAK, 1998:3).

A partir dos dados, obtém-se as informações e estas são frutos dos dados dentro de um contexto específico. Com o aumento das iniciativas em gestão do conhecimento, observa-se que as palavras informação e conhecimento, muitas vezes, são tratadas como se tivessem o mesmo significado. É importante fazer-se uma diferenciação entre estas duas palavras para que se consiga entender a origem do conhecimento e a tentativa de geri-lo.

A confusão nas definições entre informação e conhecimento, traz uma preocupação potencializada nas organizações que iniciam projetos em gestão do conhecimento. Essa confusão pode acabar gerando uma quantidade enorme de informações, com as quais as pessoas não conseguem discernir o que é útil ou não, e a empresa, esperando que os usuários tomem suas decisões com base nessas informações, nem sempre obtém sucesso (VASCONCELOS, 2001:98-102), da mesma forma como o que foi comentado sobre questões relacionadas à tecnologia.

Para definir informação, Crawford (1993:21) recorre ao Webster, apontando-a como "notícia ou inteligência transmitidas por palavras ou na forma escrita; fatos ou dados”.

Davenport e Prusak (1998:4) entendem a informação como:

“... uma mensagem, geralmente na forma de um documento ou uma comunicação audível ou visível. Como acontece com qualquer mensagem, ela tem um emitente e um receptor. A informação tem por finalidade mudar o modo como o destinatário vê algo, exercer algum impacto sobre seu julgamento e comportamento. Ela deve informar; são os dados que fazem a diferença”. 
A partir dos dados, obtêm-se uma informação relevante que está inserida em um contexto determinado, sendo, também passível de interpretação pessoal e assim, situando-se num estágio anterior à formação do conhecimento. Atualmente, com a tecnologia da informação e a Internet, o acesso às informações tem sido cada vez mais fácil e abrangente, e grandes também têm sido os benefícios extraídos das tecnologias e dos softwares empregados para tal. O uso, por exemplo, de correio eletrônico é altamente difundido entre as organizações, facilitando a comunicação e reduzindo custos.

Dada a importância e os critérios com que a tecnologia da informação deve ser tratada e implementada, a capacidade dos executivos para guiar e influenciar ações relacionadas com gerenciamento e uso destas tecnologias nas estratégias de negócios tem sido reconhecida como competência crítica (MAÇADA e BECKER, 2001:88).

De dados, obtêm-se informações e destas, obtêm-se conhecimento. Parte-se, então, para a difícil tarefa de tentar definir o que vem a ser o conhecimento, sem pretensões filosóficas como já observado. Ao definir conhecimento, a literatura de gestão tem freqüentemente observado o conhecimento tácito e explícito. A diferenciação entre esses dois tipos de conhecimento é tratada ainda neste Capítulo.

Faz-se aqui uma tentativa de buscar a definição e responder à pergunta "o que é conhecimento?”. Acredita-se que, no ambiente empresarial, pode ser possível defini-lo, porém seria pretensão enorme tentar obter um consenso geral sobre o assunto. Concorda-se com Grant* (apud OLIVEIRA JÚNIOR, 2001:132) quando afirma que “desde que esta questão tem intrigado alguns dos maiores pensadores do mundo, desde Platão a Popper, sem a emergência de um claro consenso, essa não é uma arena que eu escolho para competir”, porém muitos autores tentaram e alguns deles são citados abaixo.

Uma observação interessante é colocada por Drucker (1999:205) que afirma que conhecimento não reside em um livro, em um banco de dados, em um programa de software; esses itens apenas contêm informações; o conhecimento é de propriedade de

\footnotetext{
* GRANT, R.M. Toward a knowledge-based theory of the firm. Strategic Management Journal, v. 17, p. 109-122, 1996 apud OLIVEIRA JUNIOR., M.M. Competências essenciais e conhecimento na empresa. In: FLEURY, M.T.L. e OLIVEIRA JUNIOR., M.M. (Orgs.). Gerenciamento estratégico do conhecimento: integrando aprendizagem, conhecimento e competências. São Paulo: Atlas, p. 121-156, 2001.
} 
alguma pessoa, é transportado por uma pessoa, é aplicado, ensinado e transmitido por uma pessoa e é usado, bem ou mal, por uma pessoa.

Então, na tentativa de dar um significado ao conhecimento, encontram-se diversas fontes, das quais três foram selecionadas para que o trabalho conte com uma terminologia específica.

Von Krogh et al. (2001:15-16) definem o conhecimento como sendo uma “crença verdadeira e justificada”, podendo ser “explícito ou tácito” e dependente de um “contexto capacitante”. O conhecimento é inerente a um julgamento pessoal, “uma construção da realidade, e não algo verdadeiro de maneira abstrata”. Pode ser externado facilmente ou está intrínseco a um processo ou a uma pessoa. Por considerar e sofrer influência do contexto, o conhecimento é “dinâmico, relacional e baseado na ação humana; depende da situação e das pessoas envolvidas e não de verdades absolutas e fatos tangíveis”. Os autores alegam que o fato do conhecimento ser diretamente influenciado pelo contexto é a principal diferença entre este e dados e informações.

Nonaka e Takeuchi (1997:63-64) adotam, em consonância com Von Krogh et al. (2001), que o conhecimento é “crença verdadeira e justificada” e “um processo dinâmico de justificar a crença pessoal com relação à 'verdade”” e “está essencialmente relacionado com a ação humana”. Também tentam diferenciar o conhecimento de informações em três aspectos:

- o conhecimento está relacionado com as crenças e os compromissos, ao contrário da informação;

- o conhecimento está relacionado com uma ação, uma atitude;

- $\quad$ o conhecimento tem de ter um significado, é contextual e relacional.

Sobre informação afirmam Nonaka e Takeuchi (1997:63-64), que “é um fluxo de mensagens, enquanto o conhecimento é criado por esse próprio fluxo de informação, ancorado nas crenças e compromissos do seu detentor".

Leonard-Barton e Sensiper (1998:113) também entendem que o conhecimento é uma informação relevante, passível de ação humana e baseado, ao menos parcialmente, em experiência.

Crawford (1993:21) recorre, a exemplo do que fez para definir informação, ao Webster para definir conhecimento, assim o coloca como sendo "os fatos, verdades ou 
princípios adquiridos, a partir de estudo ou investigação; aprendizado prático de uma arte ou habilidade; a soma do que já é conhecido com o que pode ser aprendido”.

A definição encontrada por Probst et al. (2002) e Davenport e Prusak (1998), na opinião do autor, são completas e exprimem o que este trabalho também entende ser abrangente quanto ao conhecimento. Por isso ambas são citadas abaixo na sua íntegra.

“Conhecimento é o conjunto total incluindo cognição e habilidades que os indivíduos utilizam para resolver problemas. Ele inclui tanto a teoria quanto a prática, as regras do dia-a-dia e as instruções sobre como agir. O conhecimento baseia-se em dados e informações, mas, ao contrário deles, está sempre ligado a pessoas. Ele é construído por indivíduos e representa suas crenças sobre relacionamentos causais” (PROBST et al., 2002:29).

"Conhecimento é uma mistura fluida de experiência condensada, valores, informação contextual $e$ insight experimentado, a qual proporciona uma estrutura para avaliação e incorporação de novas experiências e informações. Ele tem origem e é aplicado na mente dos conhecedores. Nas organizações, ele costuma estar embutido não só em documentos ou repositórios, mas também em rotinas, processos, práticas e normas organizacionais” (DAVENPORT e PRUSAK, 1998:6).

Havendo uma série de definições de conhecimentos, para uma melhor terminologia, pode-se fazer uma padronização, de forma a entender o conhecimento como tendo um panorama dinâmico que sofre ação do julgamento e da crença individual. O seu uso e sua fonte não são esgotáveis e cabe ao indivíduo buscar um aprimoramento contínuo de seus conhecimentos, à organização cabe estabelecer formas para que as pessoas desenvolvam os conhecimentos que a empresa necessita para obter e manter sua vantagem competitiva, atuando tanto na criação de novos conhecimentos como, também, na observação e na utilização dos que a organização já detém.

Diversos dos autores, acima citados na tentativa de definição do conceito de conhecimento, abordam a existência do conhecimento tácito e do conhecimento explícito. Tanto Nonaka e Takeuchi (1997:65), Davenport e Prusak (1998:87), Von Krogh et al. (2001:15-16) e Leonard-Barton e Sensiper (1998:113) concordam e usam 
como base os conceitos definidos por Michael Polanyi, e também o consideram como precursor deste assunto. Michael Polanyi escreveu, em 1966, sobre as dimensões tácitas e explícitas do conhecimento, o que resultou no entendimento dado pelos autores citados às duas formas apresentadas de conhecimento.

“O conhecimento tácito é pessoal, específico ao contexto e, assim, difícil de ser formulado e comunicado. Já o conhecimento explícito ou codificado refere-se ao conhecimento transmissível em linguagem formal e sistemática” (NONAKA e TAKEUCHI, 1997:65).

A discussão sobre conhecimento tácito e explícito tem se tornado muito importante, sobretudo pela dimensão tácita do conhecimento individual, no ambiente organizacional. Além de se tentar criar diariamente novos conhecimentos, também se procura muito entender o que já se sabe (LEONARD-BARTON e SENSIPER, 1998:127), mostrando que o conhecimento expresso em palavras e números representa apenas a ponta do iceberg do conjunto de conhecimentos como um todo (NONAKA e TAKEUCHI, 1997:65).

A diferenciação de conhecimento tácito e explícito é abordada em outras partes deste trabalho, visto que, a transformação de conhecimento tácito em explícito, ou seja, sua transferência, é considerada um dos pilares essenciais do processo de gestão do conhecimento.

Neste item, procurou-se observar o conhecimento individual no ambiente organizacional. Nos próximos itens deste Capítulo, essa discussão é retomada, para que haja um entendimento de conhecimento coletivo e sua possibilidade de transferência e compartilhamento.

\subsection{Conhecimento e competências: o capital humano}

No item anterior, observaram-se as definições de dados, informações e conhecimento; neste item, o assunto é ampliado para o conceito de competências, é feita uma distinção entre as competências individuais e as competências organizacionais. Neste mesmo contexto, é dado o entendimento do que hoje tem se chamado de capital humano, dentro de um panorama de estudos sobre o capital intelectual.

A exemplo da dificuldade encontrada para definir o que é conhecimento, uma competência pode aparecer com diversos significados. Isso acontece devido a um 
direcionamento, acredita-se, de qual linha de raciocínio e ideologia um trabalho pretende seguir, porém a maior parte das definições encontradas convergem para o mesmo destino.

Na teoria da Administração podem-se encontrar ilustrações acerca de três aspectos que medem a efetividade de um profissional: conhecimentos, habilidades e atitudes (MAXIMILIANO, 1995:74-75); o conhecimento é o saber, a habilidade é o saber fazer e a atitude é o saber ser e agir (RUAS, 2001:249). Dentro das habilidades, autores como Chiavenato (1997:5) abordam as habilidades em três distinções: técnica, humana e conceitual. A habilidade técnica é referente ao uso específico de conhecimento, em determinada área de especialização; a habilidade humana retrata o trabalho com pessoas e socialização dos grupos e a habilidade conceitual deve ser característica dos níveis gerenciais da organização e consiste em compreender o processo de tomada de decisões complexas, que afetam o todo da empresa.

Essa discussão mostrada acima sobre conhecimentos, habilidades e atitudes serve para mostrar que o tratamento dado ao tema não é novo e diversos trabalhos sobre teoria da Administração procuram entender esses conceitos, sobretudo no trabalho gerencial. Henry Mintzberg, em sua obra “A natureza do trabalho gerencial” (1973:186193), aponta uma série de habilidades que as escolas de administração deveriam ensinar aos gerentes, para que estes sejam eficazes; em síntese, são habilidades de: relacionamento, liderança, resolução de conflitos, processamento de informações, tomada de decisões, alocação de recursos, empreendedorismo e auto-análise.

Schermerhorn Júnior (1999:9-10) define uma habilidade como “a capacidade de transformar conhecimento em ação" e concorda com as habilidades técnicas, humanas e conceituais citadas acima.

Essa definição de habilidade em que se conecta o conhecimento com a ação, associada com a atitude, ou seja, a aplicação das regras aprendidas para resolver problemas complexos, se assemelha muito ao que alguns autores (ULRICH, 2000:13; QUINN et al. 1996: 71-80) definem como know how ou know how social.

Avançando na busca de uma definição de competência, Fleury e Fleury (2000:21) comentam que estas são sempre contextualizadas e que o Know-how e conhecimento adquirem status de competência quando podem ser comunicados e trocados. 
Uma competência pode ser inerente ao indivíduo ou à organização, (ULRICH, 2000:13; FLEURY e FLEURY, 2000:21; RUAS, 2001:248). A competência individual pode ser técnica ou social/cultural (ULRICH, 2000:13), ou, em uma outra abordagem, ser de negócio, técnico-profissional e social (FLEURY e FLEURY, 2000:24). A competência da organização pode ser técnica (essencial) ou social/cultural (ULRICH, 2000:13). Podem, ser também, classificadas como competências sobre processos, técnicas, sobre a organização (organizar ou fluxos de trabalho), de serviços e sociais (ZARIFIAN* apud FLEURY e FLEURY, 2000:23).

A Figura 3.3 relaciona as competências como fonte de valor para o indivíduo e para a organização, e integra a definição de competência do profissional sugerida por Fleury e Fleury (2000:21): “um saber agir responsável e reconhecido, que implica mobilizar, integrar, transferir conhecimentos, recursos, habilidades, que agreguem valor econômico à organização e valor social ao indivíduo”.

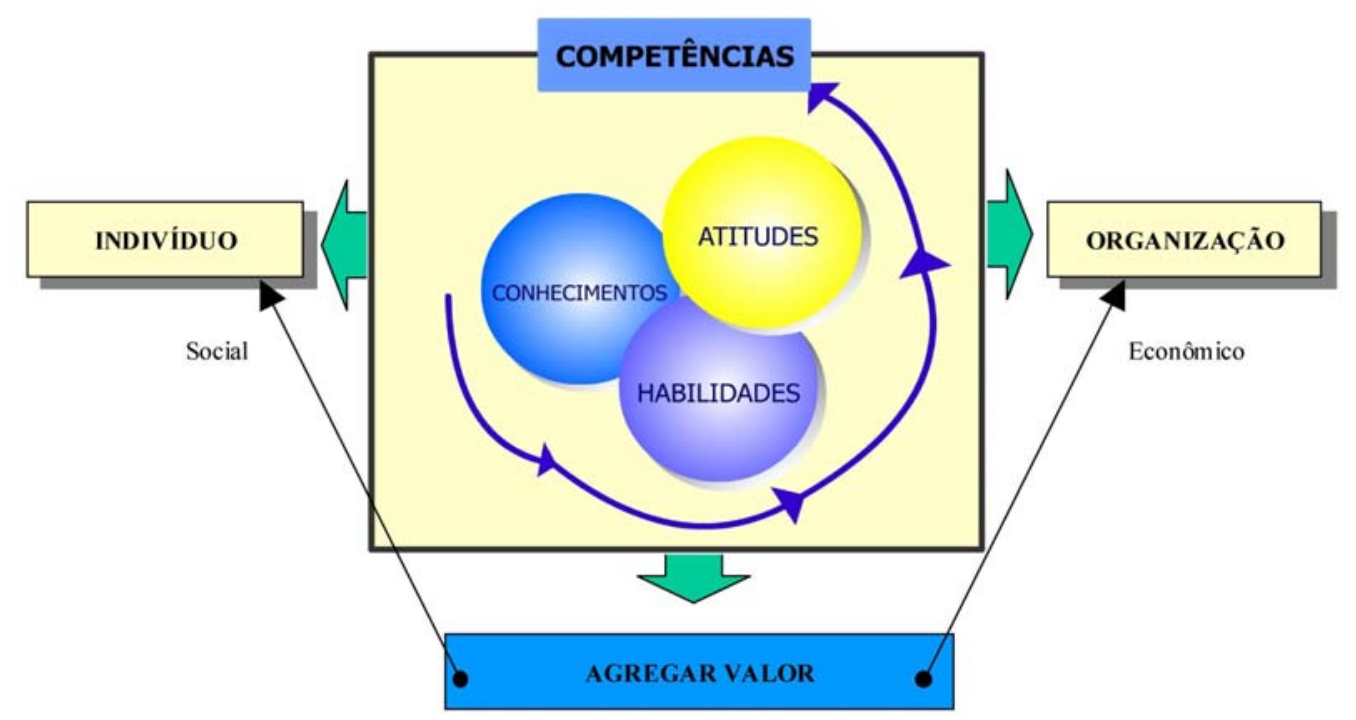

Figura 3.3 As Competências na Organização.

Adaptado de Fleury \& Fleury, 2000:21

No mesmo sentido, Ruas (2001:248) coloca que competência não está só relacionada com uma quantidade de conhecimento que alguém detém nem tampouco sua formação educacional ou profissional, "não se reduz ao saber, nem ao saber fazer, mas à sua capacidade de mobilizar e aplicar esses conhecimentos e capacidades numa

* ZARIFIAN,P. Objectif compétence. Paris: Liaisons, 1999 apud FLEURY, A. e FLEURY, M.T.L. Aprendizagem e inovação organizacional: um quebra-cabeça caleidoscópico da indústria brasileira. São Paulo: Atlas, 2000, p. 23. 
condição particular, na qual se colocam recursos e restrições próprias à situação específica”.

É possível, observando-se as definições acima, considerar que os elementos tornados clássicos na teoria administrativa - conhecimento (saber), habilidade (saber fazer) e atitude (saber ser e agir) - são genéricos para entender uma competência de um indivíduo, ao menos no que diz respeito a uma competência social. Com uma competência técnica, outros fatores precisam ser considerados.

Nesse ponto, às considerações de Ruas (2001:248-249) sobre estes três elementos (conhecimento, habilidade e atitude) como tendo uma abrangência para qualquer circunstância como composição da competência individual, deve-se acrescentar, para o entendimento de competência neste trabalho, que existem desdobramentos e especificidades que contribuem para uma maior objetividade no entendimento do recurso competência.

As considerações de Fleury e Fleury (2000:18-26) acerca das competências do indivíduo parecem bastante completas. É destacado que estas competências podem ser:

- competências técnicas: são as competências relacionadas com uma área especifica de atuação;

- competências do negócio: compreendem a visão estratégica - a contribuição individual no entendimento e divulgação da estratégia da empresa, e planejamento - a elaboração de ações específicas que visam alcançar a estratégia proposta;

- competências sociais: incluem competências relacionadas com capacidades de comunicação, negociação e trabalho em equipe.

Sem dúvida alguma, existe uma série de outras competências que poderiam ser relacionadas como sendo importantes, inclusive, no ambiente organizacional, mas esta busca, além de trabalhosa não reflete a intenção do trabalho. Para que seja possível migrar da competência individual para a competência organizacional, o Quadro 3.1 traz uma matriz em que são diferenciadas as competências em social/cultural e técnica, em uma análise individual e organizacional. 
Quadro 3.1 - Competências Individuais e Organizacionais

\begin{tabular}{|c|c|c|c|}
\hline & \multicolumn{2}{|c|}{ Nível de Análise } \\
\hline & & Individual & Organizacional \\
\hline \multirow{2}{*}{ 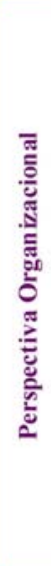 } & 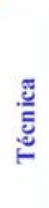 & \begin{tabular}{l}
\multicolumn{1}{c}{1} \\
Competências funcionais ou \\
técnicas, tais como capacidades \\
individuais em finanças, \\
engenharia, marketing, \\
atendimento ao cliente, etc.
\end{tabular} & \begin{tabular}{l}
\multicolumn{1}{c}{3} \\
Competência essencial, tais como \\
capacidades organizacionais em \\
logística, gerenciamento de risco, \\
distribuição, produção, etc.
\end{tabular} \\
\hline & 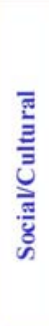 & \begin{tabular}{l}
\multicolumn{1}{c}{2} \\
Competências sociais, tais como \\
capacidades de liderança \\
individual no estabelecimento de \\
direção (visão, cliente), na \\
mobilização de comprometimento \\
pessoal (diversidade), na \\
alavancagem das organizações \\
(trabalho em equipe, mudança), \\
credibilidade pessoal etc.
\end{tabular} & \begin{tabular}{l}
\multicolumn{1}{c}{4} \\
Competência organizacional, tais \\
como capacidades organizacionais \\
em velocidade, tempo de ciclo, \\
alavancagem de capital intelectual, \\
em vencer limitações, etc.
\end{tabular} \\
\hline
\end{tabular}

Fonte:Ulrich, 2000:13.

Uma das grandes discussões atuais sobre vantagem competitiva inclui a questão sobre competências da organização, ou seja, de uma forma simplista, o que a organização sabe e faz bem feito; porém, quando se tenta entender mais o que vem a ser uma competência da organização, começa-se a encontrar um inter-relacionamento entre aspectos individuais com as estruturas gerenciais de cada empresa, o que uma empresa faz para criar valor.

Von Krogh et al. (2001:96) afirmam que uma competência é a aplicação com êxito de um conhecimento, exclusivo e valioso, que uma empresa detém, em atividades que são criadoras de valor através de uma exploração de oportunidades de negócios existentes.

King et al. (2002:37) entendem as competências de uma forma ampla em que “combinam conhecimento e habilidade; representam tanto a base de conhecimento tácito quanto o conjunto de habilidades, necessários para a realização de ações produtivas" e destacam, também, que as competências "compreendem a soma de conhecimentos presentes nas habilidades individuais e nas unidades organizacionais”.

Completando este sentido de competência, Ulrich (2000:13) destaca as competências essenciais ou capacidades organizacionais (Quadro 3.1). Estas capacidades são “o elo entre a estratégia e ação”.

O conceito de competência essencial foi mais divulgado pelo trabalho de Prahalad e Hamel (1990:79-91): 
“As competências essenciais são o aprendizado coletivo na organização, especialmente no que diz respeito a como coordenar as diversas habilidades de produção e integrar as múltiplas correntes de tecnologia ... está associada à organização do trabalho e a entrega de valor ... é comunicação, envolvimento e um profundo comprometimento em trabalhar além das fronteiras organizacionais ... não diminuem com o uso, ao contrário de recursos físicos que se deterioram com o tempo. ... As habilidades que, juntas, constituem a competência essencial devem florescer em torno de indivíduos cujos esforços não sejam estreitamente focalizados, para que eles consigam reconhecer as oportunidades. ... As competências são os elementos que ligam os negócios existentes.”

Porém é importante destacar que o conceito já existia anteriormente não é novo, de acordo com Leonard-Barton (1995:16):

“... vários autores têm denominado-as como competências distintivas (Snow e Hrebiniak, 1980; Hitt e Ireland, 1985), competências essenciais ou organizacionais (Prahalad e Hamel, 1990; Hayes, Wheelwright e Clark, 1988), competências firma-específicas (Pavitt, 1991), desenvolvimento de recursos (Hofer and Schendel, 1978) e ativos invisíveis (Itami e Roehl, 1987)”.

Uma competência organizacional tem diversas características, abordadas por diversos autores, concordando com Prahalad e Hamel (1990), que destacam este recurso com fonte real para se obter ou defender uma vantagem competitiva. Abaixo são descritas algumas consideradas importantes:

- uma competência não tem proprietário, ela é corporativa, abrange toda a organização, não pertence a um único indivíduo, serve a diversos produtos e sua importância para a vantagem competitiva é consenso entre todos; King et al. (2002:39), Ulrich (2000:13) e Rumelt* (apud Oliveira Júnior, 2001:127);

\footnotetext{
* RUMELT, R. Competence-based competition. Nova York: John Wiley, 1994 apud OLIVEIRA JUNIOR, M.M. Competências essenciais e conhecimento na empresa. In: FLEURY, M.T.L. e OLIVEIRA JUNIOR., M.M. (Orgs.). Gerenciamento estratégico do conhecimento: integrando aprendizagem, conhecimento e competências. São Paulo: Atlas, p. 121-156, 2001.
} 
- agregam valor para os clientes: competências são definidas como importantes por pessoas de fora da empresa; King et al. (2002:39), Ulrich (2000:13), Rumelt*, Probst et al. (2002:25), Savage (1996:41) e Von Krogh et al. (2001:96);

- $\quad$ as competências são estáveis no tempo, mantêm a continuidade por longos períodos, têm robustez perante mudanças ambientais, os produtos são expressões momentâneas de uma competência essencial da organização; King et al. (2002:38), Ulrich (2001:14), Rumelt*, Savage (1996:41) e Lei et al. (2001:160);

- não são facilmente copiadas, este é o seu caráter tácito que dificulta a sua codificação e divulgação e oferecem exclusividade; Savage (1996:41), King et al. (2002:38), Ulrich (2000:14), Probst et al. (2002:25) e Lei et al. (2001:160);

- promove compromisso do funcionário, uma competência ganha significado entre os trabalhadores e estabelece identidade para a organização com seus clientes, funcionários, fornecedores e investidores (ULRICH, 2000:14);

- $\quad$ as competências podem ter diversas localizações, embora esteja relacionada com a organização e não tenha um proprietário exclusivo, uma competência pode estar vinculada ao conhecimento e habilidades das pessoas-chave, nos sistemas físicos como banco de dados, softwares equipamentos e outros programas, aos sistemas gerenciais e à missão, cultura e valores da organização; Leonard-Barton (1995:19), King et al. (2002:39) e Ulrich (2000:14).

Como percebido, as competências consideram, além do conhecimento e da habilidade individuais, as rotinas gerenciais e as tecnologias que uma organização utiliza. Uma competência é um fenômeno socialmente complexo. Oliveira Júnior (2001:146) afirma que uma competência é composta em grande parte de conhecimento tácito, fato que a torna, como já afirmado, de difícil cópia e coloca algumas dimensões de conhecimento que compõem uma competência:

- conhecimentos e habilidades acumuladas dos funcionários;

- conhecimento embutido nos sistemas técnicos, incluindo software, banco de dados relacionados e procedimentos formais; 
- $\quad$ sistemas gerenciais que existem para criar e controlar o conhecimento;

- $\quad$ valores e normas que ditam que informações devem ser coletadas, que tipos são mais importantes e como devem ser utilizados.

Uma abordagem bastante ampla sobre as competências organizacionais é dada por Leonard-Barton (1995:4-27), que destaca que as competências estratégicas realmente concedem uma vantagem competitiva à organização, são desenvolvidas ao longo do tempo e conseguir copiá-las é tarefa difícil para os concorrentes. O interessante na visão desta autora, é a colocação da competência organizacional num conjunto mais complexo de atividades inerentes à gestão da empresa. Destaca que a competência essencial é um sistema composto por competências técnicas qualificações pessoais e conhecimento incorporado nos sistemas físicos - e "duas dimensões que canalizam e controlam o conhecimento - os sistemas de gestão, que sustentam e reforçam o incremento do conhecimento através da educação e de incentivos cuidadosamente planejados; e valores que servem para filtrar e encorajar ou desencorajar a acumulação de diferentes tipos de conhecimentos”.

Este último entendimento de competência da organização começa a entrar no campo inerente à gestão, mais especificamente à gestão do conhecimento, ou seja, começa a observar a competência como resultado de algumas iniciativas adotadas pela empresa que facilitam ou não a criação e o compartilhamento do conhecimento. No próximo item se destacam elementos dos processos da gestão do conhecimento que definem melhor estas passagens.

\subsection{Elementos da gestão do conhecimento}

Nesta parte do trabalho, é feita uma abordagem ao processo da gestão do conhecimento, ou seja, as etapas mais importantes da iniciativa de tentar tornar o conhecimento como um recurso estratégico. Para isso, são consideradas algumas etapas do processo de gestão do conhecimento destacadas na literatura. Neste sentido, Davenport e Prusak (1998:61) colocam os processos da gestão do conhecimento como sendo: (1) a geração do conhecimento, (2) codificação e coordenação do conhecimento e (3) transferência do conhecimento; já Probst et al. (2002:36) ampliam este processo abordando os seguintes pontos: (1) identificação do conhecimento, (2) aquisição do 
conhecimento, (3) desenvolvimento do conhecimento, (4) partilha/distribuição do conhecimento, (5) utilização do conhecimento e (6) retenção do conhecimento.

São considerados, neste trabalho, cinco elementos principais, dentro do processo de gestão do conhecimento, que mais têm relação com a proposta da dissertação:

- $\quad$ identificação do conhecimento;

- codificação e transferência do conhecimento;

- $\quad$ aquisição do conhecimento;

- criação do conhecimento.

\subsubsection{Identificação do conhecimento}

O conhecimento que as empresas detêm não é facilmente visível, nem tampouco o conhecimento que os concorrentes detêm, assim, uma das primeiras etapas (PROBST et al., 2002:33) para um processo de gestão do conhecimento é a identificação do conhecimento interno e externo.

Para tentar saber como as empresas concorrentes têm atuado no mesmo mercado, Probst et al. (2002:64) afirmam que um dos recursos utilizados com muita freqüência é a prática do benchmarking, "um processo contínuo e sistemático para avaliar produtos, serviços e processos de trabalho de organizações que são reconhecidas como representantes das melhores práticas” (SPENDOLINI, 1993:10) de um determinado setor ou segmento, visando melhoria organizacional, competitividade, comparação organizacional e estabelecimento de metas, entre outros.

Provavelmente a prática do benchmarking pode trazer alguns benefícios importantes para a organização, como por exemplo, o estabelecimento de metas desafiadoras, a quebra de paradigmas, a criação de linhas de ação e modelos para excelência. Porém não é capaz de mostrar “como” um concorrente faz ou chega a determinada competência. Uma competência é um recurso raro, valioso e socialmente complexo e inclui fenômenos organizacionais como reputação, confiança, cultura, história e relação com o mercado, tornando a cópia de uma competência ou capacidade organizacional uma caminhada difícil (BARNEY, 1995:49-61).

Porém, pode ser utilizado para a identificação do conhecimento interno que a empresa detém, o benchmarking interno, para que as práticas de outras divisões ou unidades de negócio sejam observadas e delas extraídos pontos de possível melhoria. O 
benchmarking interno pode ser definido como o "processo de identificação, compartilhamento e uso do conhecimento e práticas de dentro da própria organização”. Além disso, este processo de benchmarking interno e transferência das melhores práticas "é uma das mais tangíveis manifestações da gestão do conhecimento e da evidência da aprendizagem organizacional” (O’DELL e GRAYSON, 1998:154).

A tecnologia da informação pode ajudar em muito as iniciativas de benchmarking interno, como groupware, correio eletrônico, sistemas de informações gerenciais e Intranet. A tecnologia não é nem o principal aliado, nem a principal barreira, neste caso. Existe a necessidade de se criar um ambiente que possibilite condições internas de as informações serem compartilhadas e, sobretudo, é uma questão de cultura da organização. Uma importante variável é o relacionamento entre as pessoas dentro da organização e o apoio da alta gerência. Existe, também, a necessidade de se estabelecer políticas de recompensas para premiar o compartilhamento de conhecimento. O benchmarking interno pode ser uma ferramenta útil para extração de conhecimento tácito de outras partes da organização e transformá-los em conhecimento explícito (O’DELL e GRAYSON, 1998:157).

A tecnologia de groupware tem sido vista há algum tempo, como forma de encorajar o compartilhamento de idéias de uma maneira muito mais livre, com um fluxo melhor que repositórios ou sistemas codificados de suporte à decisão. Colaboração é, de fato, fortemente conducente para geração e transferência de conhecimento. Groupware consiste no software projetado para auxiliar grupo de pessoas, geralmente distantes fisicamente, mas que trabalham em conjunto. O groupware se propõe a aumentar a cooperação e a comunicação interpessoais. Ao contrário do foco estritamente técnico de outras tecnologias de computação o groupware apresenta fortes dimensões sociais e organizacionais (RUGGLES, 1998:84).

Algumas formas de identificação do conhecimento têm sido utilizadas em algumas organizações, como listas de especialistas, páginas amarelas e mapas de conhecimento (PROBST et al., 2002:66-67, DAVENPORT e PRUSAK, 1998:88-94 e VON KROGH et al., 2001:191). O principal objetivo dessas ferramentas é localizar conhecimentos importantes, dentro da organização e, depois, publicá-los ou deixá-los disponíveis aos interessados, em forma de lista ou on line, em uma página de Intranet, por exemplo. Como afirmam Davenport e Prusak (1998:88) “a principal finalidade e o 
mais evidente benefício de um mapa do conhecimento é mostrar para as pessoas de dentro da empresa para onde ir quando necessitarem de conhecimento”.

Para definir o que são "páginas amarelas” é usado o mesmo exemplo explorado tanto por Davenport e Prusak (1998:89), Probst et al. (2002:66) quanto Ruggles (1998:85), em que o fabricante suíço de produtos químicos Hoffman-LaRoche resolveu deixar visível mundialmente o conhecimento dos seus pesquisadores. Para agilizar o processo de aprovação de novos medicamentos, a empresa listou todos os problemas que já haviam acontecido nas diversas etapas do processo, juntamente com o nome das pessoas que já tinham resolvido este tipo de problema anteriormente. As informações foram publicadas em forma de páginas amarelas e distribuídas por toda a organização, facilitando o acesso aos especialistas internos.

Os mapas do conhecimento têm a finalidade principal de identificar conhecimento, podem ser realizados através de banco de dados que contenham listas e descrições das competências dos indivíduos de dentro da empresa e, eventualmente, podem, também, conter informações de especialistas de fora da organização (TERRA, 2001:238). Os mapas do conhecimento também podem ser usados como uma ferramenta que avalia os conhecimentos que a empresa precisa desenvolver (DAVENPORT e PRUSAK, 1998:89). Assim, em termos gerais, “os mapas do conhecimento são representações gráficas de especialistas, ativos de conhecimento ou aplicações do conhecimento" e "mostram quais pessoas em uma equipe, uma organização ou no ambiente externo podem contribuir com conhecimento importante para tarefas específicas” (PROBST et al.,2002:67-68).

Já Von Krogh et al. (2001:191) abordam os mapas do conhecimento como mapas de cooperação compartilhados e destacam que podem ser representados por simples organogramas, explicitação de projetos de criação de conhecimento e, por fim, detalham que a forma mais valiosa destes mapas são os mapas de competências, que podem mostrar, de maneira clara, as competências e habilidades das pessoas envolvidas em projetos específicos. Nesses mapas são detalhadas as tarefas que cada equipe realiza em determinado projeto e a contribuição individual de cada membro. A contribuição pode vir de determinada pessoa com vasta competência e conhecimento em melhoria da imagem corporativa, por exemplo, e se essa competência, estiver disponível no mapa e este ser de fácil acesso, pode ser utilizada sempre que necessário. 
Novamente, as tecnologias de groupware e Intranet podem ser úteis para a publicação dos mapas de conhecimento corporativo (DAVENPORT e PRUSAK, 1998:94).

Os mapas do conhecimento necessitam de um contexto específico para serem implementados, porém, não só os mapas, mas também a gestão do conhecimento de uma forma geral, pois deve haver condições capacitadoras no ambiente para que as pessoas se sintam confortáveis em compartilhar o que sabem com os demais, sendo essa intrínseca à cultura da organização e seus valores internos.

Probst et al. (2002:69-70) abordam os possíveis problemas que os mapas podem causar se a organização não tiver preparo para implementá-lo. O mais importante diz respeito à dinamicidade que os mapas precisam ter, devendo ser “documentos vivos”. Os dados e informações colocados nos mapas precisam ser bastante precisos, é necessário haver também uma terminologia comum para que todos possam entender seu vocabulário. Além disso, à organização cabe incentivar o uso e o aproveitamento dos conhecimentos constantes no mapa e formular as medidas de premiações específicas pelo uso e estimular a cooperação.

Como já observado, o processo de identificação do conhecimento pode mostrar à organização que ela tem alguma defasagem de conhecimento. Através do benchmarking interno ou dos mapas do conhecimento, é possível checar se existe este conhecimento dentro da empresa; se existir e a empresa tiver capacidade de absorvê-lo, a defasagem pode ser superada mais facilmente. Se esse conhecimento não estiver dentro da organização, através do benchmarking externo pode ser observado se existe fora da empresa, porém, como já mencionado anteriormente, só a prática do benchmarking não é suficiente para revelar o que há por traz de uma competência. Se esse conhecimento ou competência existir fora da empresa, pode ser avaliada a possibilidade de adquiri-lo através de diversas formas: imitação, recrutamento, parcerias e outras (assunto que é tratado no próximo item). Finalmente, se o conhecimento não existir nem dentro da organização nem no mercado, é uma defasagem que pode gerar uma inovação importante e uma fonte certa de vantagem competitiva (LEONARD-BARTON, 1995, PROBST et al., 2002, DAVENPORT e PRUSAK, 1998 e O’DELL e GRAYSON, 1998). 


\subsubsection{Codificação e transferência do conhecimento}

Já foram abordados, neste trabalho, os conceitos de conhecimento tácito e explícito. O conhecimento tácito é inerente ao indivíduo, não é fácil de ser ensinado através de palavras, ou seja, é difícil de ser codificado. O conhecimento tácito envolve uma percepção individual e uma capacidade especifica em determinada atividade estando relacionado com o know how. O conhecimento explícito é aquele que pode ser ensinado e copiado com mais facilidade; muitas vezes, seu ensinamento pode ser feito por manuais e livros. Para sua obtenção, a organização pode usar diversas técnicas, inclusive comprá-lo de fontes externas. Por isso, por seu caráter exclusivo, o conhecimento tácito e sua conversão em conhecimento explícito formam um dos pilares básicos e essenciais do processo da gestão do conhecimento.

Alguns autores diferem de outros na terminologia adotada para o processo da gestão do conhecimento, porém muitos elementos que constróem esse processo são semelhantes em diversas interpretações.

Parte-se do pressuposto que a gestão do conhecimento tem a finalidade principal de criar competências organizacionais que permitem à empresa construir e sustentar suas vantagens competitivas, dando-se grande destaque ao aspecto do indivíduo nesse processo. Como se acredita na premissa de que o conhecimento tácito é a principal fonte de vantagem competitiva, por fornecer capacidade de localização e resolução de problemas, permitindo aos seus detentores anteciparem situações (LEONARDBARTON e SENSIPER, 1998:114-115), esta parte é iniciada com as formas de conversão do conhecimento destacadas por Nonaka (1991:96-104) no seu artigo para a Harvard Business Review intitulado "Criação de conhecimento na empresa”.

Nonaka (1991:98-99) e Nonaka e Takeuchi (1997:68-78) exploram quatro formas de conversão de conhecimento:

- Socialização: é a conversão do conhecimento tácito em conhecimento tácito. “A socialização é um processo de compartilhamento de experiências e, a partir daí, da criação do conhecimento tácito, como modelos mentais ou habilidades técnicas compartilhadas”. Esta conversão pode ser exemplificada pelo aprendizado de um discípulo com o seu mestre. Através da observação, da imitação e da prática o aprendiz consegue captar a essência de como o trabalho é feito. Porém, para a organização, esse 
conhecimento continua sendo tácito porque, mesmo com a socialização, a organização não consegue alavancá-lo, ainda não é conhecimento compartilhado;

- combinação: é a conversão do conhecimento explícito em conhecimento explícito. “A combinação é um processo de sistematização de conceitos em um sistema de conhecimento”. Quando as pessoas se juntam para conversar sobre características relacionadas a algum projeto e passam as suas informações sobre o assunto, esta combinação acaba por gerar um novo conhecimento para a organização. Reuniões, redes de comunicação computadorizadas, como correio eletrônico, documentos e conversas ao telefone são formas de se fazer a combinação. A combinação dá origem ao conhecimento sistêmico;

- externalização: a conversão do conhecimento tácito em conhecimento explícito. Segundo os autores, aqui se encontra um dos grandes desafios em se tentar administrar o conhecimento, “converter conhecimento tácito em conhecimento explícito significa descobrir meios de expressar o inefável”. Sugere o uso de simbologias e linguagens figurativas para alcançar este fim, "pode ser expresso na forma de metáforas, analogias, conceitos, hipóteses e modelos”. Dão como exemplo de transformação do conhecimento tácito em explícito, a escrita, que é uma forma de representar uma idéia ou percepção, ou seja, uma crença verdadeira justificada. A externalização cria conhecimento conceitual;

- internalização: conversão do conhecimento explícito em tácito está relacionada ao aprender fazendo, ou seja, as pessoas conseguem incorporar às suas habilidades ao seu know how, o novo conhecimento, que é criado quando o funcionário ou grupo acrescenta ao seu conjunto de conhecimentos mais este que lhe foi ensinado ou aprendido espontaneamente. A internalização forma o conhecimento operacional.

A Figura 3.4 traz uma ilustração dos conceitos apresentados. O destaque a ser dado no modelo de criação do conhecimento apresentado acima é a questão da conversão do conhecimento. O ciclo mostra que pode existir um grande volume de conhecimento na organização, na forma tácita, e sua externalização pode dar origem a 
uma competência, que possibilitará o fortalecimento do conhecimento e sua utilização como recurso fundamental. Mostra, também, que quanto maior for o fluxo do ciclo, maior será o crescimento do conhecimento organizacional.

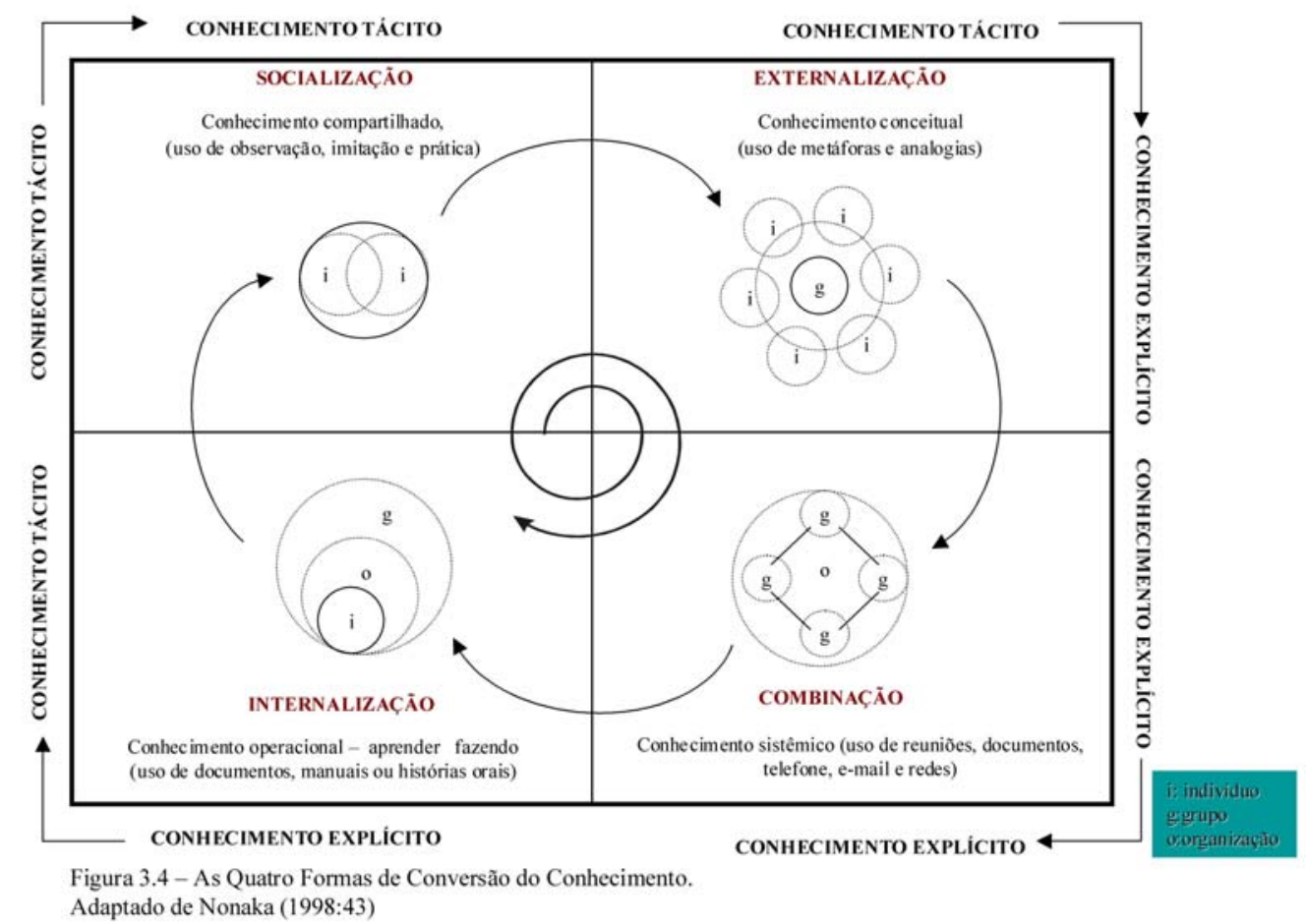

Esta conversão do conhecimento que Nonaka e Takeuchi (1997: 68-78) sugerem é uma sistematização de uma das etapas mais críticas da gestão do conhecimento: a transferência de conhecimento. As pesquisas mostram (RUGGLES, 1998:80-89) que as barreiras culturais e comportamentais são empecilhos graves para a transferência do conhecimento, fazendo com que, muitas vezes, iniciativas em gestão do conhecimento sejam verdadeiros fracassos.

O que Nonaka e Takeuchi (1997:68-78) mostram na proposta de conversão do conhecimento é também destacado de outra forma por Davenport e Prusak (1998:107) que afirmam que "várias questões e estratégias de transferência do conhecimento ... se resumem a descobrir maneiras eficazes de permitir que os indivíduos conversem e escutem o que se tem a dizer”.

Alguns autores (DAVENPORT E PRUSAK, 1998:109, PROBST et al. 2002:136 e VON KROGH et al. 2001:318) consultados neste trabalho fazem uma divisão no processo de transferência do conhecimento e destacam que esta transferência pode ser estruturada ou não-estruturada. A transferência do conhecimento estruturada é 
aquela formalizada, que, geralmente, tem apoio de tecnologia de informação; a nãoestruturada é informal ou cotidiana baseada na comunicação interpessoal dentro da organização.

Davenport e Prusak (1998:110-117) sugerem que a transferência de conhecimento através de conversas pessoais pode ser bastante produtiva e geradora de criatividade entre os indivíduos e grupos, porém advertem que essa forma de transferência do conhecimento está sendo ameaçada por gerentes que ainda se encontram na era industrial e não conseguiram entender as modificações sofridas pelo mundo e pelas organizações, com o advento da era do conhecimento.

Obviamente, a forma de transferência do conhecimento não-estruturada tem um importante valor para a organização e está diretamente relacionada com a cultura organizacional, tendo um peso maior, dependendo da organização analisada. Porém muitos casos, sobretudo em grandes empresas com sedes em diversas localidades, a forma estruturada de transferência do conhecimento, amparada na tecnologia da informação é mais efetiva e atinge amplitudes maiores, no entanto, continua relacionada à cultura da organização.

Von Krogh et al. (2001:318) e Probst et al. (2002:149-155) sugerem algumas ferramentas para a transferência do conhecimento como Internet, Intranet e Groupware, convergindo também para a necessidade de uma mudança cultural que possibilite que a organização faça benchmarking interno e transferência de melhores práticas entre departamentos e unidades. Von Krogh et al. (2001:318) levantam, por fim, ao abordarem a transferência do conhecimento, a importância da aplicação do pensamento sistêmico, uma das disciplinas sugeridas por Senge (1999:45-46), juntamente com outras quatro. Segundo o autor, o pensamento sistêmico deve integrar e servir de base para estas outras quatro disciplinas que objetivam tornar a empresa uma organização que aprende. Essas disciplinas são relatadas ainda neste Capítulo.

É possível observar que a transferência do conhecimento também é um processo que exige uma mudança cultural substancial na organização, ou, ao menos, uma adequação. O Quadro 3.2 mostra os possíveis atritos e as possíveis soluções para se moldar uma cultura organizacional que atenda às iniciativas de transferência do conhecimento. 
Quadro 3.2 Transferência do Conhecimento: Possíveis Atritos e Soluções

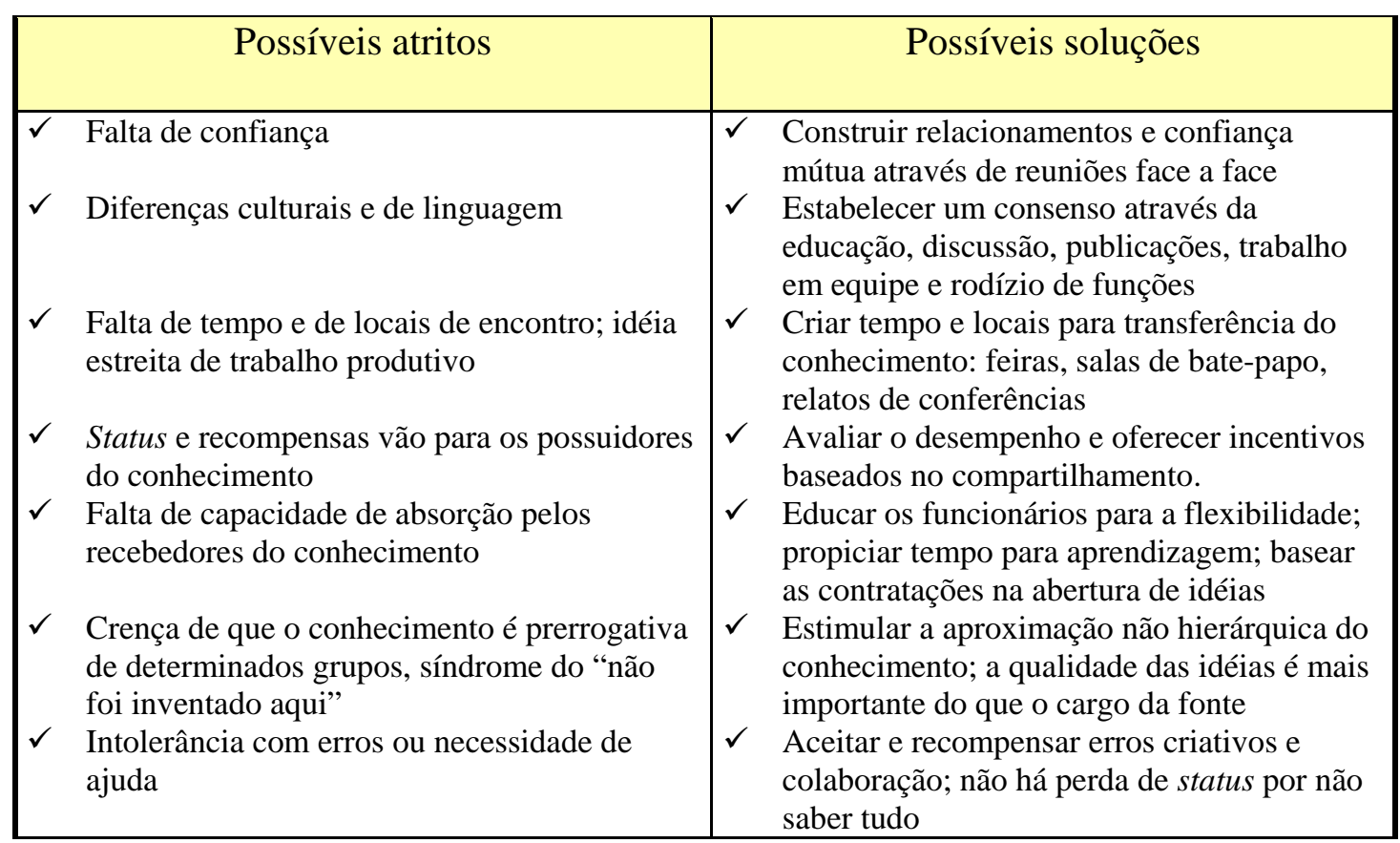

Fonte: Adaptado de Davenport e Prusak (1998:117-118).

\subsubsection{Aquisição de conhecimento}

Dado um diagnóstico de uma defasagem existente, uma organização pode decidir adquirir, de fontes externas, o conhecimento que julga importante para o desenvolvimento de determinada competência que pode trazer maior vantagem competitiva. A aquisição de conhecimentos ou competências é parte integrante de um processo de gestão do conhecimento. Neste trabalho não se tem o propósito de aprofundamento nesse item, porém são destacados alguns aspectos considerados importantes.

Existem diversas formas de adquirir conhecimentos ou competências fora da organização. Essa escolha deve refletir um posicionamento estratégico da empresa e estar suplantada em uma percepção de mercado de longo prazo.

A forma mais comum de aquisição de conhecimento é o recrutamento de pessoal, ou seja, a organização pode considerar que não tem, naquele momento, mãode-obra qualificada para determinada função ou projeto e pode partir para um recrutamento externo, para buscar o especialista na área que deseja.

A escolha de contratação de conhecimento de especialistas externos também deve considerar o contexto da organização, pois possíveis barreiras podem ser criadas 
pelo grupo de funcionários, se não houver uma transparência neste processo (DAVENPORT e PRUSAK, 1998:65 e PROBST et al., 2002:91). O recrutamento e a seleção são tratados com mais atenção na parte referente à gestão de pessoas deste trabalho.

Além da contratação de especialistas individuais em alguma área, outras formas de aquisição de conhecimento têm sido freqüentemente empregadas pelas organizações. Estas formas incluem (PROBST et al. 2002:91, DAVENPORT e PRUSAK, 1998:6566, LEONARD-BARTON, 1995:152):

- contratação de consultores externos;

- $\quad$ alianças estratégicas e parceiras;

- clientes;

- universidades;

- fusão com outra organização;

- $\quad$ aquisição de outra companhia;

- joint ventures;

- desenvolvimento compartilhado.

Uma vez identificado o conhecimento ou a competência externa que a empresa pode buscar para ter maior vantagem competitiva, Leonard-Barton (1995:152) considera que existem diversas opções de alianças estratégicas que a organização pode fazer, com diversos parceiros, para buscar o conhecimento desejado. Entre esses parceiros se destacam as universidades, os clientes, consultores, vendedores, laboratórios, organizações concorrentes e outras organizações não concorrentes, o que permite que sejam feitos diversos tipos de parcerias, como joint ventures, chegando-se até as formas mais radicais de fusões e aquisições.

\subsubsection{Criação de conhecimento: as condições capacitantes}

Nos itens anteriores foram abordadas, dentro do processo da gestão do conhecimento, a identificação, a codificação e transferência e a aquisição de conhecimentos ou competências.

A criação do conhecimento, tratada neste tópico, é uma das passagens mais difundidas pela literatura quando o assunto é gestão do conhecimento. É importante 
destacar que não se considera apenas a inovação que culmina em novos produtos ou serviços, como resultado de criação de conhecimento.

Como é possível observar no entendimento de Drucker (1999:176) que acredita existirem três tipos de novos conhecimentos:

- o aperfeiçoamento contínuo do processo, produto ou serviço, o aperfeiçoamento de tudo o que a organização faz, algo como aquilo que os japoneses chamam de Kaizen;

- a exploração do conhecimento existente, desenvolvendo novas aplicações com base naquilo que a empresa já sabe;

- $\quad$ a inovação genuína, que deve ser organizada como um processo sistemático.

Probst et al. (2002:109) também concordam, quando afirmam que o desenvolvimento de novos conhecimentos não está restrito aos departamentos de pesquisa e desenvolvimento, mas pode acontecer em todas as áreas da empresa. A criação de conhecimento inclui o “desenvolvimento de novas habilidades, novos produtos, idéias melhores e processos mais eficientes”.

É nesta etapa do processo, que o entendimento da gestão do conhecimento mais se funde com os conceitos da aprendizagem organizacional, pois, são consideradas premissas de aprendizado constante para a criação de conhecimento, algo como defendem Nonaka e Takeuchi (1997:71) de externalização, ou seja, a conversão do conhecimento tácito em conhecimento explícito, sendo uma busca através de processos que permitam a organização combinar o que já sabe e obter benefícios disso. A primeira parte, a identificação do conhecimento, já se mostrou uma etapa demasiadamente árdua, porém, os esforços sendo grandes, os resultados apresentados, na maioria das vezes são satisfatórios e bastante potencializadores das competências que a organização detêm (O’DELL e GRAYSON, 1998:155).

A introdução desse item é importante para que seja possível observar a contextualização em que se dá uma possível criação de conhecimento em uma empresa, cujas características fundamentais, como a cultura organizacional precisam ser consideradas. A cultura organizacional pode assim ser entendida: 
“A cultura é formada pelo conjunto de pressupostos básicos que um grupo inventou, descobriu, ou desenvolveu, ao aprender a lidar com os problemas de adaptação externa e integração interna e que funcionaram bem o suficiente para serem considerados válidos e ensinados a novos membros como a forma correta de perceber, pensar e sentir com relação a esses problemas” (SCHEIN* apud FLEURY e FLEURY, 1997:24).

O desafio é tentar buscar uma cultura que torne propícios o aprendizado e a criação de conhecimento organizacional. Para isso, Fleury e Fleury (1997:29) prescrevem uma mudança gradual nos padrões culturais da organização, em que os “novos valores são complementares aos existentes, ampliando o leque de alternativas para a solução de problemas”, pois, como afirmam Fleury (1996:25) e Pettigrew (1996:147) é possível gerenciar a cultura organizacional, porém a tarefa inclui grandes dificuldades.

Para uma melhor compreensão desse processo, a criação de conhecimento, dentro da gestão do conhecimento, surge a necessidade de um melhor entendimento do ambiente organizacional, ou seja, do contexto de gerenciamento da empresa. Nonaka e Takeuchi (1997:83) abordam esta questão como sendo necessária à criação de condições capacitadoras para a criação do conhecimento organizacional. Esse contexto capacitante, ou o que chamam, em japonês de $b a$, como sendo um local comum apropriadamente preparado para a criação e troca de conhecimento, foi definido por Nonaka e Konno (1998:40) e Von Krogh et al. (2001:64).

É importante entender que esse contexto capacitante ou lugar comum não significa um lugar físico específico apenas, mas combina aspectos de um espaço físico, o lay out de um escritório, por exemplo, com aspectos de um espaço virtual amparado pela tecnologia de informação, como correio eletrônico, Intranet e recursos de teleconferências, combinando, por fim, com aspectos de um espaço mental, experiências idéias e emoções compartilhadas (VON KROGH et al. 2001:66).

Esse último aspecto, o espaço mental, tem relação com a mudança cultural acima mencionada e assemelha-se ao trabalho da disciplina dos modelos mentais -

* SCHEIN, E. Organizational culture and leadership. San Francisco: Jossey-Bass, 1986 apud FLEURY, A. e FLEURY, M.T.L. Aprendizagem e inovação organizacional: as experiências de Brasil, Coréia e Japão. São Paulo: Atlas, 1997, p. 24. 
“pressupostos profundamente arraigados, generalizações ou mesmo imagens que influenciam nossa forma de ver o mundo e de agir” - proposto por Senge (1999:42), que destaca que o trabalho com esta disciplina constitui rica ferramenta para a mudança de paradigmas e equilíbrio entre indagação e argumentação “em que as pessoas exponham de forma eficaz seus próprios pensamentos e estejam abertas à influência dos outros”. Nonaka e Takeuchi (1997:77) destacam que os modelos mentais, juntamente com o know how técnico, são componentes do conhecimento tácito.

Com mais aprofundamento, Nonaka e Takeuchi (1997:83-95) exploram essas condições capacitadoras para que a organização crie um contexto apropriado para a criação do conhecimento organizacional, que são: intenção (da alta gerência), autonomia (dos trabalhadores do conhecimento), flutuação e caos criativo, redundância e variedade de requisitos. A seguir, são abordadas cada uma destas condições com busca em outras fontes na literatura, para um melhor entendimento ou questionamento.

A primeira condição capacitadora citada por Nonaka e Takeuchi (1997:83), a “intenção” ou melhor, intenção organizacional, “que é definida como a aspiração da organização às suas metas" e complementam que "os esforços para alcançar a intenção assumem a forma de estratégia dentro do contexto de uma empresa”.

Neste sentido, pode ser importante a construção ou instilação na organização de uma visão comum, ou o que Senge (1999:43) chama de visão compartilhada, “um conjunto de princípios e práticas orientadas ... envolvendo as habilidades de descobrir 'imagens de futuro' compartilhadas, que estimulem o compromisso genuíno e o envolvimento, em lugar da mera aceitação”. Também destacado por Collins e Porras (1996:65-77) como ideologia essencial, "uma identidade que transcende os ciclos de vida do produto ou mercado, avanços tecnológicos, modismos de gerenciamento e líderes individuais”, esta ideologia essencial é composta pelos valores essenciais que são as doutrinas duradouras de uma organização e o propósito essencial, que é a razão de ser de uma empresa. Ou, como observam Von Krogh et al. (2001:130-131), uma visão do conhecimento, que tem o objetivo de orientar e mostrar à organização três aspectos inter-relacionados: “(1) o mundo em que vivem, (2) os mundos em que devem viver e (3) o conhecimento que devem buscar e criar”.

A questão de uma visão unificada nas organizações, em uma sociedade do conhecimento, é considerada por Drucker (1999b:64-74) como um dos grandes desafios da alta administração. Assim, a estratégia deve servir para atender aos propósitos da 
organização para com a sociedade e a gestão do conhecimento como uma ferramenta para esse fim.

Um exemplo interessante de propósito e valores essenciais é dado por Collins e Porras (1996:65-77), citando a indústria americana de medicamentos Merck (Quadro 3.3):

Quadro 3.3 Propósito e Valores da Empresa Merck.

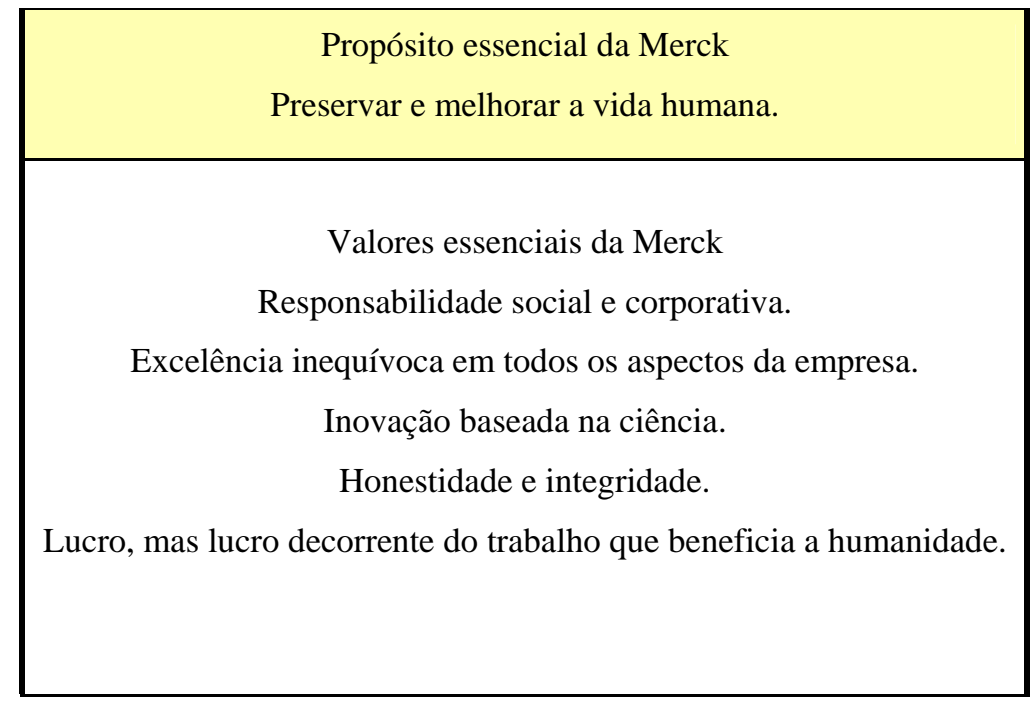

Fonte: Adaptado de Collins e Porras (1996:65-77)

Na verdade, a questão do propósito e das metas da organização é vista por Schneider et al. (1995:747-773) como operacionalizações da personalidade dos fundadores ou da alta administração. Esses propósitos e metas resultam na representação de políticas e práticas específicas para alcançá-las, e a combinação das metas e políticas e práticas resultam numa organização caracterizada por estrutura, processo e cultura únicos, e concluem que as escolhas dos fundadores e da alta gerência ajudam a construir a cultura organizacional.

O propósito e os valores da Merck confirmam essa premissa acima citada como verdadeira, pois são resultado dos anseios de seu fundador, George W. Merck, que afirmou em certa ocasião (COLLINS e PORRAS, 1996:65-77):

"Nós tentamos nunca nos esquecer de que os medicamentos são para as pessoas. E não para se obter lucro. Os lucros virão automaticamente e sempre que nos lembrarmos disso, eles nunca deixarão de vir... Como levar os melhores 
medicamentos a todas as pessoas? Não podemos permanecer sentados até que o caminho tenha sido descoberto; com nossa ajuda, devemos chegar a todas nossas melhores descobertas”.

Leonard-Barton (1995:24) concorda que, na maioria das companhias, “as premissas básicas acerca da natureza humana e os valores pessoais dos fundadores levam ao estabelecimento de uma série de valores empresariais”.

A abordagem desta autora (LEONARD-BARTON, 1995:3-56) é salutar pois faz um comparativo interessante afirmando que a organização tem sistemas que criam as competências essenciais e permitem o fluxo de conhecimento, porém estes mesmos sistemas também criam aquilo que a autora denomina de limitações essenciais (core rigidies), ou seja, atividades que inibem a criação e transferência do conhecimento e destaca entre elas os valores e normas organizacionais. Esses sistemas são:

- conhecimentos e qualificações dos empregados, determinando três dimensões diferentes de conhecimentos e qualificações possíveis, ou seja, os conhecimentos públicos ou científicos, os conhecimentos que são específicos à indústria e aqueles que são específicos à firma;

- Sistemas técnicos físicos: o conhecimento não reside apenas na cabeça das pessoas, ele também é encampado nos sistemas físicos - máquinas, bancos de dados e softwares. A característica principal dos sistemas físicos é o acúmulo de conhecimento de diversos especialistas em suas estruturas de softwares e hardwares;

- sistemas de gestão: “a acumulação de conhecimentos, por parte do empregado, é norteada e monitorada pelos sistemas de instrução, remuneração e incentivos da companhia. Esses sistemas de gestão, especialmente as estruturas de incentivos, criam canais por onde o conhecimento flui e é acessado; eles também impõem barreiras a atividades geradoras de conhecimento indesejado", ou seja, "são as rotinas organizadas que orientam a acumulação e o uso estratégico de recursos”;

- $\quad$ valores e normas: neste item, afirma que o conhecimento e as qualificações das pessoas que estão incorporadas nos sistemas físicos e nos sistemas de gestão tomam um dimensão específica, dependendo do que é valorizado na empresa e "determinam que tipo de conhecimento deve-se buscar e cultivar, 
que tipos de atividades geradoras de conhecimento deve-se tolerar e encorajar”.

A segunda condição capacitadora sugerida por Nonaka e Takeuchi (1997:85) é a autonomia dos funcionários e os autores defendem o que chamam de equipe autoorganizada. De fato, a questão do empowerment parece ser uma característica das organizações na era do conhecimento, bem como a diminuição dos níveis hierárquicos (TERRA, 1999:128 e LEONARD-BARTON, 1995:261), porém essa questão se mostra bastante ampla e também dependente de todo o contexto. Savage (1996:235) adota o termo equipes dinâmicas focadas em tarefas e afirma que o risco das equipes autogerenciadas ou ad hoc é a sua desconexão com a vida organizacional.

Quando se acredita que o conhecimento, diferente dos fatores de produção tradicionais - terra, trabalho e capital - é criado na mente das pessoas e por suas atitudes e comportamentos e que, tanto sua criação quanto sua transferência são atividades intangíveis, isto é, não podem ser supervisionadas nem forçadas, essas atividades apenas acontecem quando as pessoas decidem colaborar voluntariamente. Isso não quer dizer que sistemas convencionais de gestão não tenham mais valor, pelo contrário, apenas há que se observar que têm um pequeno impacto para encorajar a cooperação ativa (KIM e MAUBORGNE, 1997:71), por isso, quando uma mudança cultural para estes padrões for uma alternativa escolhida, é necessário que haja processos justos para criar comprometimento com as metas organizacionais.

A ruptura entre organização da era industrial e o início da era do conhecimento é ilustrada por Savage (1996:223-242), como sendo:

- de gerenciamento da rotina para gerenciamento da complexidade;

- de hierarquias íngremes para redes do conhecimento;

- de comando e controle para foco e coordenação;

- de autoridade da posição para autoridade do conhecimento;

- de atividades seqüenciais para atividades simultâneas;

- de comunicação vertical para comunicação horizontal;

- de desconfiança e complacência para confiança e integridade.

A terceira condição organizacional sugerida por Nonaka e Takeuchi (1997:88) é a flutuação e o caos criativo. Quanto à flutuação, sugerem que a organização deve 
atentar para os detalhes do ambiente externo. A flutuação não significa desordem e “trata-se de uma ordem cujo padrão é difícil de prever inicialmente”. Quanto ao caos criativo, destacam que pode surgir em uma ocasião de crise real ou ser intencionalmente sugerida pela alta gerência, através do estabelecimento de metas desafiadoras. Destacam, também, que o limiar entre o caos criativo e o caos destrutivo é a habilidade das pessoas de analisar e refletir sobre suas próprias ações.

Na teoria sobre aprendizagem organizacional, sobretudo no trabalho de Senge (1999:169), há uma defesa da mesma questão com o nome de “tensão criativa”, ou seja, a lacuna existente entre a visão que o indivíduo tem, justaposta com o diagnóstico, da realidade atual. A tensão natural em busca da solução dos problemas é uma tensão saudável, que gera energia para atingir os objetivos propostos. Essa tensão criativa defendida por Senge é a base de uma das suas disciplinas, o domínio pessoal.

Finalmente, Nonaka e Takeuchi (1997:91-94) completam o ciclo proposto para a criação do conhecimento com as condições capacitadoras de redundância e variedade de requisitos. Destacam que a redundância é “a superposição intencional de informações sobre atividades da empresa” e que a variedade de requisitos tem relação com a diversificação na força de trabalho da organização, capacitando-a para enfrentar situações adversas. Abordam também o fato que, para aumentar a variedade é necessário tornar as informações acessíveis, em todos os níveis da empresa.

Davenport e Prusak (1998:73), ao comentarem esses conceitos, esclarecem que Nonaka e Takeuchi tomam emprestado o termo da cibernética para descreverem um conflito produtivo como o defendido por Leonard-Barton (1995:63-64), como sendo a abrasão criativa. A energia gerada por conflitos de idéias, predisposições, personalidades e valores, a capacidade de questionamento de conceitos pré-existentes pode gerar esta abrasão criativa, porém, não é só conseguida com a diversidade e com o confronto ou o questionamento, "seu propósito específico é contribuir para a inovação e incentivar a integração de diferentes métodos de abordar e solucionar problemas - a fim de criar algo que nenhuma perspectiva isolada poderia proporcionar”.

É de grande importância, quando se tem a intenção de abordar o tema de gestão do conhecimento ou da aprendizagem organizacional, fornecer condições para que o ambiente seja propício a essas iniciativas. Tanto a literatura sobre gestão de conhecimento citada acima, como aquela sobre aprendizagem organizacional dão 
destaque a esses aspectos organizacionais. Abaixo são consideradas outras capacitações importantes para o assunto tratado.

Senge (1999:40-44) sugere cinco disciplinas, que se inter-relacionam, de aprendizagem organizacional, para que a organização crie condições para a criação e transferência de conhecimento, são:

- domínio pessoal, pois a organização aprende por meio de indivíduos aptos a aprender. A aprendizagem individual, não apenas o aprendizado ou treinamento de uma tarefa ou habilidade específica, enfoca o desenvolvimento da pessoa com o trabalho. Esta disciplina condensa o diagnóstico de uma realidade atual que a pessoa vive, com aquilo que realmente deseja e ao que pretende chegar; a diferença entre esses dois pontos cria a tensão criativa, que dá motivação para a pessoa estabelecer ações para atingir os objetivos desejados;

- modelos mentais "são pressupostos profundamente arraigados, generalizações ou mesmo imagens que influenciam nossa forma de ver o mundo e de agir”. São as crenças dos indivíduos que sugerem roteiros para suas ações individuais mediante interpretação dos fatos que acabam formando uma cultura comum na organização. Uma total hegemonia entre os modelos mentais ou uma completa divergência podem ser prejudiciais à organização, causando muita rigidez ou falta de entendimento entre os membros;

- visão compartilhada, é a construção de objetivos comuns que motivem o grupo a alcançá-los com grande engajamento. O papel de instilar esta visão, que cabe ao líder, dá o direcionamento da empresa e sua projeção para o futuro. É com essa visão que o grupo todo trabalha para conquistar esses objetivos;

- $\quad$ aprendizagem em equipe é a construção da competência da organização, a passagem da aprendizagem individual para a aprendizagem do grupo. O diálogo é ingrediente essencial para este fim;

- pensamento sistêmico, que é a quinta disciplina sugerida, e que deve fazer uma integração com as outras quatro anteriores, visa aprimorar o processo de aprendizagem como um todo. É um modelo desenvolvido ao longo dos 
últimos 50 anos, tem demonstrado ser uma importante ferramenta para a aprendizagem.

Ainda sobre a aprendizagem organizacional, Garvin (1993:78-91) sugere cinco blocos de construção para uma organização que aprende, defendendo também a integração destes blocos no cotidiano empresarial que se complementam com atitudes mentais e padrões de comportamento entre si:

- $\quad$ solução de problemas de maneira sistemática: são fundamentos emprestados do movimento da qualidade, com ferramentas amplamente aceitas e utilizadas atualmente como: confiar em métodos científicos para o diagnóstico do problema, insistir em dados, no lugar de pressupostos, como alicerce do processo decisório e utilizar ferramentas estatísticas para organizar as informações e fazer inferências;

- experimentação: esta atividade envolve a busca sistemática e o teste de novos conhecimentos. Assume duas formas básicas: programas contínuos que são pequenos experimentos capazes de proporcionar ganho incremental ao conhecimento. A melhoria contínua e os projetos de demonstração de diferentes espécies são geralmente grandes programas de experimentos complexos, que envolvem todo o sistema organizacional;

- aprendizado com as próprias experiências: a organização que aprende constrói uma memória das suas experiências anteriores, os fracassos e os sucessos, e as torna lição acessível para todos os seus membros. O autor afirma que as experiências anteriores, sobretudo o fracasso, são importantes fontes de conhecimento e aprendizado;

- aprendizado com os outros: é saber olhar o ambiente externo em que a organização está inserida e tirar proveito dele. A prática de benchmarking tem sido constantemente utilizada para esta finalidade;

- transferência de conhecimentos: o conhecimento adquirido ou produzido não pode se manter como assunto local, precisa circular de forma rápida por toda a organização. $\mathrm{O}$ autor sugere alguns processos para que isso aconteça: apresentações escritas, orais ou visuais, visitas e excursões a outras localidades, programas de rodízio de pessoal, programas de educação e treinamento, relatórios, entrevistas e programas de padronização. 
Outra contribuição importante para as condições capacitadoras para a gestão do conhecimento e aprendizagem organizacional é dada por Von Krogh et al. (2001:1820), que abordam cinco capacitadores de conhecimento:

- instilar a visão do conhecimento: legitima as iniciativas de criação de conhecimento em toda a empresa;

- gerenciar as conversas: fase chave do processo sugerido pelos autores, foca a compartilhamento explícito de conhecimento entre os membros e tem influência em todo o ciclo da gestão do conhecimento;

- mobilizar os ativistas do conhecimento: enfatiza as pessoas que iniciam e coordenam os processos de criação de conhecimento;

- criar o contexto adequado: tem relação direta com a estrutura que a empresa adota para que o ciclo do conhecimento seja favorecido;

- globalizar o conhecimento local: enfatiza a disseminação do conhecimento por todos os níveis organizacionais.

Muitos pontos em comum são citados por Leonard-Barton (1995:19) ao abordar as competências essenciais de uma organização. Sobretudo quando se trata de desenvolvimento de novos produtos em aspectos tecnológicos, levanta quatro atividades geradoras e difusoras de conhecimento:

- solução compartilhada de problemas: diminuição das fronteiras organizacionais e construção de uma cultura em que a resolução criativa e inteligente dos problemas é função de todos os membros na organização. Neste item, a autora aborda o assunto abrasão criativa, a energia positiva gerada a partir dos conflitos;

- implementação e integração de novas metodologias e tecnologias;

- $\quad$ experimentação e prototipagem;

- importação e absorção de conhecimento de fontes externas.

O Quadro 3.4 resume uma série de contribuições importantes para que haja criação e transferência de conhecimento em iniciativas de gestão do conhecimento. 


\section{Quadro 3.4 - Condições para a Criação e Transferência do Conhecimento}

\begin{tabular}{|c|c|c|c|c|c|c|c|}
\hline & $\begin{array}{l}\text { Nonaka e } \\
\text { Takeuchi } \\
(1997) \\
\end{array}$ & & Senge (1999) & & Garvin (1993) & $\begin{array}{c}\text { Von Krogh et al. } \\
\text { (2001) }\end{array}$ & $\begin{array}{c}\text { Leonard - Barton } \\
\text { (1995) }\end{array}$ \\
\hline$\checkmark$ & $\begin{array}{l}\text { Intenção } \\
\text { Organizacional }\end{array}$ & $\checkmark$ & $\begin{array}{l}\text { Domínio } \\
\text { pessoal }\end{array}$ & $\checkmark$ & $\begin{array}{l}\text { Solução de } \\
\text { problemas de } \\
\text { maneira } \\
\text { sistemática }\end{array}$ & $\begin{array}{ll}\checkmark & \text { Justificar a } \\
\text { visão de } \\
\text { conhecimento }\end{array}$ & $\begin{array}{ll}\checkmark & \text { Solução } \\
\text { compartilhada de } \\
\text { problemas }\end{array}$ \\
\hline$\checkmark$ & $\begin{array}{l}\text { Autonomia dos } \\
\text { trabalhadores }\end{array}$ & $\checkmark$ & $\begin{array}{l}\text { Modelos } \\
\text { mentais }\end{array}$ & $\checkmark$ & Experimentação & $\begin{array}{l}\checkmark \quad \text { Gerenciar as } \\
\text { conversas }\end{array}$ & $\begin{array}{l}\checkmark \quad \text { Implementação e } \\
\text { integração de } \\
\text { novas } \\
\text { metodologias e } \\
\text { tecnologias }\end{array}$ \\
\hline$\checkmark$ & $\begin{array}{l}\text { Flutuação e } \\
\text { caos criativo }\end{array}$ & $\checkmark$ & $\begin{array}{l}\text { Visão } \\
\text { compartilhada }\end{array}$ & $\checkmark$ & $\begin{array}{l}\text { Aprendizagem } \\
\text { com as próprias } \\
\text { experiências }\end{array}$ & $\begin{array}{ll}\checkmark & \text { Mobilizar os } \\
& \text { ativistas do } \\
& \text { conhecimento }\end{array}$ & $\begin{array}{l}\checkmark \quad \text { Experimentação e } \\
\text { prototipagem }\end{array}$ \\
\hline \multirow[t]{2}{*}{$\checkmark$} & \multirow[t]{2}{*}{$\begin{array}{l}\text { Redundância e } \\
\text { variedade e } \\
\text { requisitos }\end{array}$} & $\checkmark$ & $\begin{array}{l}\text { Aprendizagem } \\
\text { em equipe }\end{array}$ & $\checkmark$ & $\begin{array}{l}\text { Aprendizado } \\
\text { com os outros }\end{array}$ & $\begin{array}{ll}\checkmark & \text { Criar o } \\
& \text { contexto } \\
& \text { adequado }\end{array}$ & $\begin{array}{l}\checkmark \text { Importação e } \\
\text { absorção de } \\
\text { conhecimento de } \\
\text { fontes externas }\end{array}$ \\
\hline & & & $\begin{array}{l}\text { Raciocínio } \\
\text { sistêmico }\end{array}$ & & $\begin{array}{l}\text { Transferência de } \\
\text { conhecimento }\end{array}$ & $\begin{array}{ll}\checkmark & \text { Globalizar o } \\
\text { conhecimento } \\
\text { local }\end{array}$ & \\
\hline
\end{tabular}




\section{GESTÃO DE PESSOAS}

Neste Capítulo, é dado destaque à contribuição da área de recursos humanos das organizações no, intuito de formar um ambiente produtivo para que as iniciativas em gestão do conhecimento sejam positivas, sobretudo em propiciar condições que permitam que a organização trabalhe com todo o ciclo da gestão do conhecimento: identificação, aquisição, criação e transferência do conhecimento.

Desta forma, recursos humanos está sendo considerado como parte fundamental na realização dos esforços para a criação de condições capacitantes à gestão do conhecimento e à aprendizagem organizacional. Terra (1999), em sua tese de doutorado, faz uma inter-relação de diversos componentes que estimulam o gerenciamento do conhecimento em uma organização, considerando gestão recursos humanos como uma das funções chave neste processo, como pode ser observado na Figura 4.1.

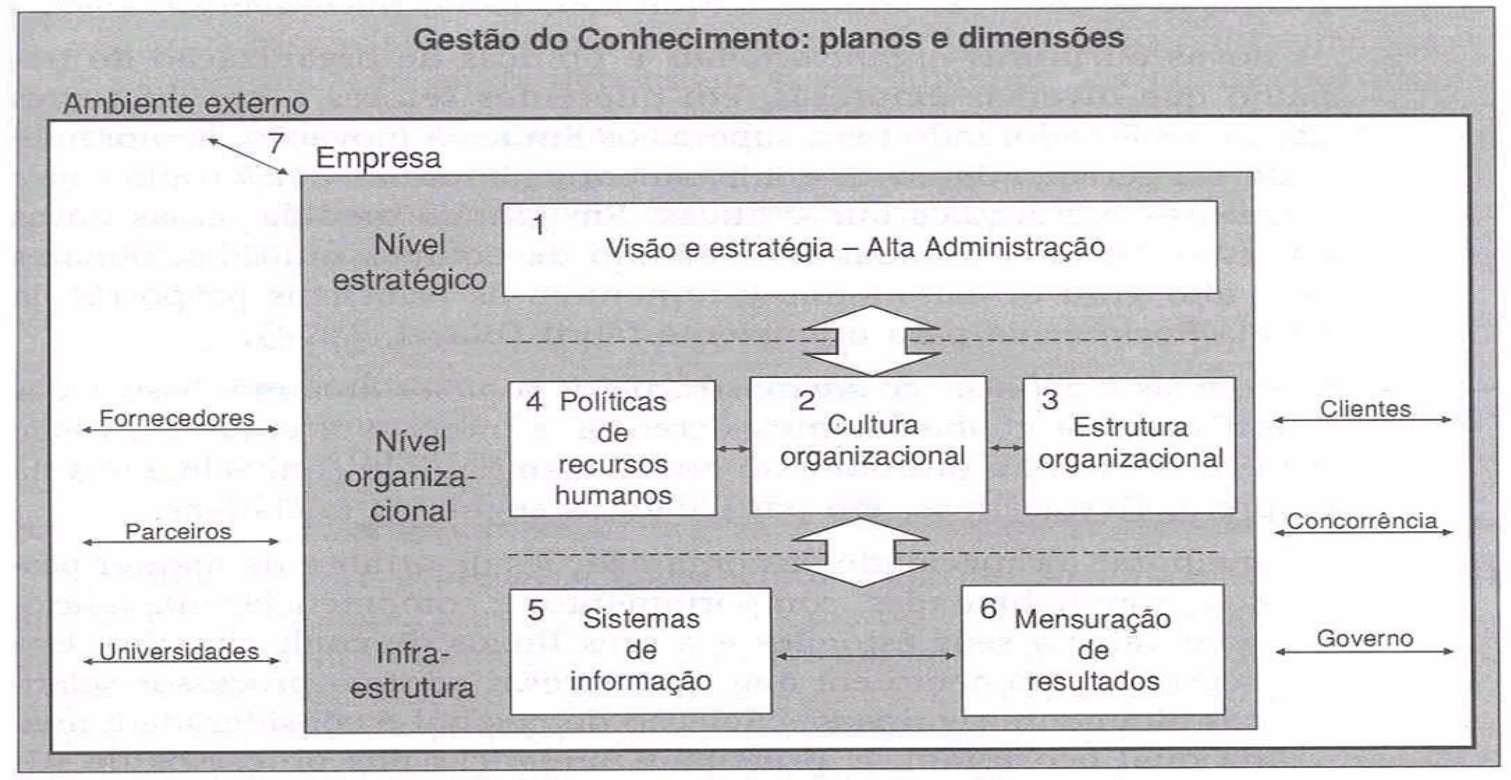

Figura 4.1 Modelo conceitual sobre gestão do conhecimento na empresa

Fonte: Terra (2001:215) 
Para que se torne mais fácil a visualização dos principais papéis e funções que recursos humanos pode desempenhar neste processo, o Quadro 4.1 traz uma esquematização do assunto que o presente Capítulo trata. Para que haja um melhor entendimento destes papéis, o quadro contém três referenciais explicativos (ULRICH, 2002:41) que se relacionam com o papel e funções da área de recursos humanos: o resultado esperado, a metáfora característica ou imagem visual que acompanha cada papel e o papel da área de recursos humanos no processo de gestão do conhecimento.

Quadro 4.1 Os Papéis de RH na Gestão do Conhecimento

\begin{tabular}{|l|l|l|l|l|}
\hline Papel/função & Resultado & Metáfora & Atividade & $\begin{array}{l}\text { Processo na gestão do } \\
\text { conhecimento }\end{array}$ \\
\hline $\begin{array}{l}\text { Administração de } \\
\text { Estratégias de Recursão }\end{array}$ & Execução da Estratégia & Parceiro Estratégico & $\begin{array}{l}\text { Ajuste das estratégias de } \\
\text { RH à estratégias } \\
\text { empresarial: "Diagnóstico } \\
\text { Organizacional" }\end{array}$ & $\begin{array}{l}\text { Identidade do } \\
\text { conhecimento }\end{array}$ \\
\hline $\begin{array}{l}\text { Administração da } \\
\text { contribuição dos } \\
\text { funcionários }\end{array}$ & $\begin{array}{l}\text { Aumento das } \\
\text { competências e do } \\
\text { comprometimento dos } \\
\text { funcionários }\end{array}$ & $\begin{array}{l}\text { Criação de Capital } \\
\text { Intelectual }\end{array}$ & $\begin{array}{l}\text { Ouvir e responder aos } \\
\text { funcionários: "Prover } \\
\text { recursos aos funcionários" }\end{array}$ & $\begin{array}{l}\text { Aquisiçãoe criação do } \\
\text { conhecimento }\end{array}$ \\
\hline $\begin{array}{l}\text { Administração da } \\
\text { transformaçãoe da } \\
\text { mudança cultural }\end{array}$ & $\begin{array}{l}\text { Criação de uma } \\
\text { organização renovada }\end{array}$ & $\begin{array}{l}\text { Agente da mudança } \\
\text { cultural }\end{array}$ & $\begin{array}{l}\text { Gerir a transformação e a } \\
\text { mudança cultural: } \\
\text { "assegurar capacidade } \\
\text { para mudança" }\end{array}$ & $\begin{array}{l}\text { Transferência do } \\
\text { conhecimento }\end{array}$ \\
\hline
\end{tabular}

Fonte: Adaptado de Ulrich (2002:41).

Desta forma, o Capítulo dividi-se em quatro itens:

4.1 Recursos humanos como parceiro estratégico: a criação da clareza estratégica.

4.2 Recursos humanos e o aumento das competências e do comprometimento dos funcionários: a criação do capital humano.

4.3 Recursos humanos como agente da mudança cultural.

4.4 Gestão de pessoas para a gestão do conhecimento: constatações da literatura.

\subsection{Recursos humanos como parceiro estratégico: a criação da clareza estratégica}

Já foi abordada, anteriormente, neste trabalho, a importância da organização explicitar suas metas e torná-las conhecidas de todo o grupo de funcionários, construindo, assim, uma visão coletiva e um sentido de caminho compartilhado por todos, Nonaka e Takeuchi (1997:83) destacam que a aspiração da organização de atingir 
suas metas, ou seja, sua intenção organizacional é uma condição capacitante vital à criação do conhecimento empresarial, Senge (1999:43), em seu trabalho sobre aprendizagem organizacional destaca a importância de se construir uma visão compartilhada, o direcionamento da empresa e a sua projeção para o futuro, o engajamento de todo o grupo na busca de objetivos comuns. Collins e Porras (1996:6577) destacam que os valores essenciais e a ideologia essencial precisam ser transparentes e amplamente divulgados para todo o grupo.

Nesta parte do trabalho, procura-se entender e mostrar a necessidade do alinhamento entre as práticas de recursos humanos e a estratégia empresarial, a estratégia do negócio em si. A área de recursos humanos passa a ser vista como um parceiro estratégico e cada estratégia de recursos humanos precisa ter direta relação com a estratégia corporativa. Baseadas em um diagnóstico organizacional, as estratégias de recursos humanos procuram fornecer capacidades organizacionais para que a estratégia do negócio seja alcançada.

Yeung e Bermam (1997:333) sugerem que a área de recursos humanos deve estar segura de que: (1) as práticas de recursos humanos estão alinhadas por diferentes caminhos para adicionar valor à performance do negócio e (2) as mensurações de recursos humanos estão corretamente formuladas para guiar as atividades e comportamentos dos profissionais de recursos humanos, dos gerentes de linha e dos demais funcionários envolvidos. Assim, sugerem que a área de recursos humanos pode estabelecer uma estrutura para o diagnóstico organizacional, considerando:

- determinar o que faz o sucesso da organização, quais são as capacidades organizacionais chave e quais devem ser construídas para prover a satisfação de todos os stakeholders - clientes, funcionários, acionistas ou proprietários;

- entender como recursos humanos pode adicionar valor para os fatores críticos de sucesso, novamente enfatizando as capacidades organizacionais que podem gerar satisfação em todos os níveis de stakeholders;

- estruturar uma mensuração adequada das atividades da área de recursos humanos considerando: suas atividades operacionais, o cumprimento das suas estratégias e o cumprimento das estratégias corporativas. 
A Figura 4.2 mostra a inter-relação existente entre as práticas de recursos humanos, as capacidades organizacionais e as estratégias empresariais, adicionando assim, valor para os funcionários, clientes e acionistas ou proprietários.

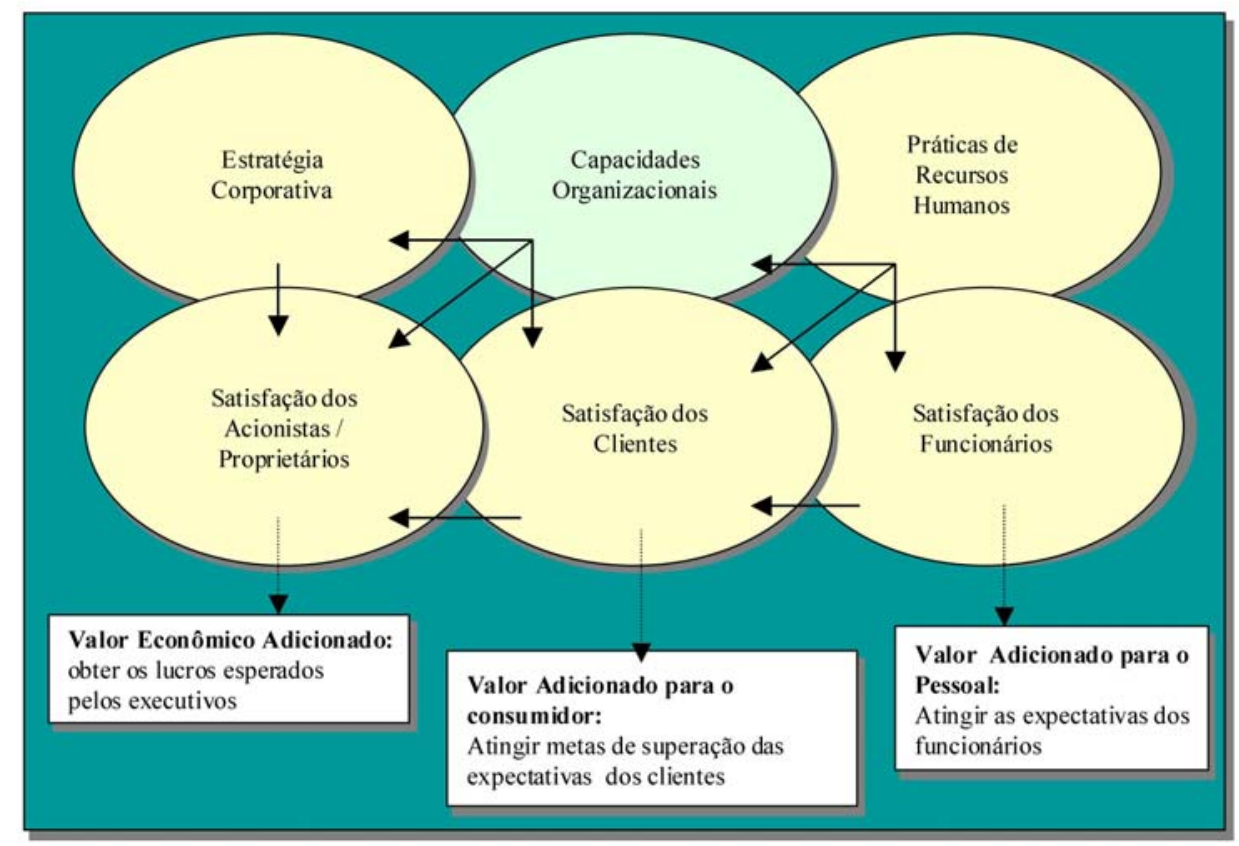

Figura 4.2 O fluxo das Capacidades Organizacionais Adaptado de Yeung and Berman (1997:328)

A contribuição de suma importância neste diagnóstico é mostrar à área de recursos humanos quais os pontos em que pode adicionar valor, bem como quais os pontos em que existem deficiências que precisam ser desenvolvidos em termos de capacidades organizacionais. Estas capacidades organizacionais são o elo entre a estratégia e a ação. Algumas de suas características são fornecidas por Ulrich (2000:1314):

- oferecem integração, se baseiam na organização e não nas pessoas;

- $\quad$ agregam valor para os clientes;

- $\quad$ oferecem exclusividade e são difíceis de se copiar;

- promovem compromisso dos funcionários;

- $\quad$ estabelecem identidade com todos os stakeholders.

Estas características de uma capacidade ou competência organizacional remetem, novamente à questão do diagnóstico organizacional em que a área de recursos humanos precisa ter papel de parceiro estratégico. 
Quando as capacidades organizacionais, que precisam ser raras e socialmente complexas, conseguem explorar as oportunidades ou neutralizar as fraquezas advindas do ambiente externo, existe a criação da vantagem competitiva. Quando as capacidades organizacionais não conseguem isto, há necessidade iminente de desenvolvimento de habilidades que gerem as capacidades requeridas pelo ambiente externo e que, provavelmente já são vantagem competitiva de alguma outra organização, por isso, a área recursos humanos tem papel importantíssimo neste entendimento das forças e fraquezas, considerando-se as capacidades organizacionais internas e as oportunidades e ameaças externas.

Segundo Ulrich (2002:42), um dos mais importantes papéis do departamento de recursos humanos "se concentra no ajuste de suas estratégias e práticas à estratégia empresarial como um todo”, assim, a área e os profissionais de recursos humanos tornam-se pouco a pouco um parceiro estratégico, “ajudando a garantir o sucesso e aumentar a capacidade da empresa em atingir seus objetivos”, ou seja, realizar sua estratégia. Define que transformar a estratégia empresarial em práticas de recursos humanos auxilia e empresa em três aspectos:

- maior adaptabilidade à mudança devido à redução de tempo, que vai da concepção à execução da estratégia;

- melhor entendimento das exigências dos consumidores porque as estratégias foram traduzidas em práticas específicas;

- melhor desempenho financeiro mediante execução mais eficaz das estratégias.

Ulrich (2002:96-97) propôs uma arquitetura para o diagnóstico organizacional que permite à área de recursos humanos sincronizar suas ações com a estratégia empresaria, tendo como base os trabalhos de David Nadler, consultor organizacional, no modelo de organização de Jay Galbraith que define cinco fatores essenciais nas organizações: estratégia, estrutura, recompensas, processos e sistemas, e também no modelo dos '7S' utilizado pela empresa McKinsey, sendo: estratégia, estrutura, sistemas, pessoal, estilo, habilidades e metas superiores (valores comuns). O Quadro 4.2 traz o modelo de diagnóstico sugerido. Na primeira linha do quadro - intenção estratégica e capacidades organizacionais - descreve-se a direção da empresa. Os demais fatores, listados abaixo, definem o modo de operação da empresa e identificam 
os sistemas que precisam mudar para que as organizações apliquem a estratégia (ULRICH, 2002:93-94):

- mentalidade comum, que representa a identidade e a cultura comuns a uma empresa;

- competências que são conhecimento, qualificações e habilidades existentes entre os funcionários e os grupos de funcionários, bem como em seus relacionamentos;

- conseqüência que representa os padrões da gestão do desempenho, incluindo medidas, sistemas de avaliação e recompensas;

- $\quad$ sistemas de comando que representam as relações hierárquicas, processos de tomada de decisão, políticas e processos de comunicação da organização;

- processo de trabalho / capacidade para a mudança que representa o modo como as organizações melhoram seus processos, administram a mudança e aprendem;

- liderança que representa o modo como as empresas formam, comunicam e comprometem-se com a direção.

Quadro 4.2 - Arquitetura para o diagnóstico organizacional

\begin{tabular}{|c|c|c|c|}
\hline \multicolumn{4}{|c|}{ Intenção Estratégica: O que estamos tentando realizar? } \\
\hline \multicolumn{2}{|c|}{$\begin{array}{l}\text { Estratégia: intenção, plano, foco, canais, etc. } \\
\text { Consumidores: segmentação, valor adicionado. } \\
\text { Finanças: medidas, retorno, valor criado. }\end{array}$} & \multicolumn{2}{|c|}{$\begin{array}{l}\text { Contexto ambiental: legislação, economia. } \\
\text { Competência Essencial: Tecnologia }\end{array}$} \\
\hline \multicolumn{4}{|c|}{ Mentalidade Comum: Pelo que desejamosser conhecidos por nossos elientes? } \\
\hline Pilar da Competência & Pilar da Consequeência & $\begin{array}{l}\text { Pilar do Sistema de } \\
\text { Comando }\end{array}$ & $\begin{array}{l}\text { Pilar do Processo de Trabalho / } \\
\text { Capacidade para mudança }\end{array}$ \\
\hline $\begin{array}{l}\text { Quais sło as competências de que } \\
\text { necessitamos para realizar nossa } \\
\text { estratégia? }\end{array}$ & $\begin{array}{l}\text { Quais słào os padrỏes e } \\
\text { consequéncias necessárias para a } \\
\text { realizaçao de nossa estratćgia? }\end{array}$ & $\begin{array}{l}\text { Qual a organizaço de que precisamos para } \\
\text { realizar nossa estratégia? }\end{array}$ & $\begin{array}{l}\text { Qual a capacidade de que dispomos para gerir os } \\
\text { processos de traballho e para mudar a fim de } \\
\text { realizar nossa estratcigia? }\end{array}$ \\
\hline $\begin{array}{l}\text { Preenchimento de eargos } \\
\text { Quem é contratado para a organizaçăo? } \\
\text { Quem é promovido na organizaçio? } \\
\text { Quem é demitido da organizaçı? } \\
\text { Desenvolvimento } \\
\text { Considerando nosso ambiente e } \\
\text { estratégias empresariais, que treinamento } \\
\text { deve ser oferecido? } \\
\text { Considerando nosso ambiente e } \\
\text { estratégias empres ariais, que alternativas } \\
\text { ao desenvolvimento devem ser } \\
\text { oferecidas? }\end{array}$ & 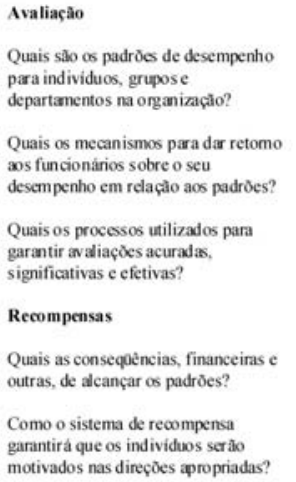 & 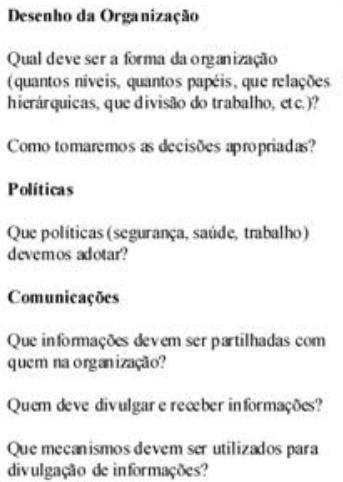 & $\begin{array}{l}\text { Melhoria dos Processos de trabal tho } \\
\text { Que tipo de iniciativa devemos ofececer para } \\
\text { garantir que nossos processos de gestâo } \\
\text { funcionam bem (qualidade, reengenharia, etc)? } \\
\text { Processos de Mudanças } \\
\text { Quais sào os processos criticos paa fauer com } \\
\text { que a mudança ocorra? } \\
\text { Fomento do Aprendizado para Mudança } \\
\text { Como podemos divulgar idcias e o aprendizado } \\
\text { além das fronteiras organizacionais? }\end{array}$ \\
\hline
\end{tabular}

Fonte: Ulrich (2002:96-97) 
Ainda a respeito da necessidade de alinhamento entre a estratégia competitiva escolhida pela empresa e as práticas de recursos humanos, Schuler e Jackson (1987:207219), também concordam que esta ligação se faz necessária e destacam que cada prática de recursos humanos deve responder a algum ponto da estratégica empresarial, respondendo a parte de um, um ou mais de um resultado específico para o alcance da estratégia do negócio. No trabalho, os autores confrontam as estratégias de inovação, diferenciação em qualidade superior e competição em custos, focando comportamentos de papéis e práticas específicas da gestão de recursos humanos.

Outro trabalho que também especifica a importância da coerência entre a estratégia e as práticas de recursos humanos é dado por Rosseau (1995:180-201) que detalha quatro comportamentos estratégicos: defensores, prospectores, analisadores e responsivos, sendo que, para cada um destes comportamentos estratégicos, define práticas de recursos humanos pertinentes. O Quadro 4.3 mostra os detalhes desta abordagem. 
Quadro 4.3 Ligando Estratégia com Práticas de Recursos Humanos.

\begin{tabular}{|c|c|c|c|c|}
\hline Estratégia & Defensora & Prospectora & Analisadora & Responsiva \\
\hline Metas & $\begin{array}{l}\text { Manter participação e } \\
\text { posição de mercado }\end{array}$ & $\begin{array}{l}\text { Adaptar-se às mudanças } \\
\text { ambientais e inovação }\end{array}$ & $\begin{array}{l}\text { Adaptar-se a diferentes } \\
\text { segmentos de mercado }\end{array}$ & $\begin{array}{l}\text { Inovação e lançamento de } \\
\text { produtos antes que os } \\
\text { concorrentes }\end{array}$ \\
\hline SUPOSIÇÕES & $\begin{array}{l}\text { Ambiente estável } \\
\text { Cultura organizacional é } \\
\text { uma vantagem } \\
\text { competitiva } \\
\text { Experiência especializada } \\
\text { da organização é válida e } \\
\text { valiosa } \\
\text { Profunda habilidade } \\
\text { funcional requerida pela } \\
\text { competitividade } \\
\text { Pessoas não substituíveis }\end{array}$ & $\begin{array}{l}\text { Ambiente dinâmico e } \\
\text { imprevisível } \\
\text { Habilidade especializada } \\
\text { da organização não são } \\
\text { valiosas, habilidades de } \\
\text { estado da arte são valiosas } \\
\text { Rápida resposta para } \\
\text { mudar é vantagem } \\
\text { competitiva } \\
\text { Baixa interdependência } \\
\text { entre os funcionários } \\
\text { Pessoas são substituíveis } \\
\end{array}$ & $\begin{array}{l}\text { Negócios são } \\
\text { segmentados } \\
\text { Mercado é diversificado } \\
\text { Pouca vantagem de } \\
\text { coordenação pelas } \\
\text { divisões }\end{array}$ & $\begin{array}{l}\text { Ambiente dinâmico } \\
\text { Recursos são escassos } \\
\text { Alta interdependência } \\
\text { entre os funcionários } \\
\text { Experiência e habilidade } \\
\text { de estado da arte são } \\
\text { valiosos }\end{array}$ \\
\hline \begin{tabular}{l|} 
PRÁtiCAS DE \\
RECURSOS \\
HuMANOS \\
\end{tabular} & $\begin{array}{c}\text { FAZER } \\
\text { (TO MAKE) }\end{array}$ & $\begin{array}{c}\text { COMPRAR } \\
\text { (TO BUY) }\end{array}$ & $\begin{array}{l}\text { FAZER E COMPRAR } \\
\text { (MAKE AND BUY) }\end{array}$ & $\begin{array}{c}\text { FAZER COM } \\
\text { COMPRAR } \\
\text { (MAKE WITH BUY) } \\
\end{array}$ \\
\hline RECRUTAMENTO & $\begin{array}{l}\text { Quase exclusivo no início } \\
\text { da carreira }\end{array}$ & $\begin{array}{l}\text { Recrutamento em todos } \\
\text { os níveis hierárquicos }\end{array}$ & Depende de cada divisão & $\begin{array}{l}\text { Considerável } \\
\text { recrutamento no início da } \\
\text { carreira } \\
\text { Pode haver recrutamento } \\
\text { em todos os níveis }\end{array}$ \\
\hline TREINAMENTO & $\begin{array}{l}\text { Extensivo e longo tempo } \\
\text { no trabalho } \\
\text { Carreira desenvolvida } \\
\text { dentro da empresa }\end{array}$ & $\begin{array}{l}\text { Pouco treinamento do } \\
\text { trabalho } \\
\text { Carreira desenvolvida } \\
\text { dentro da indústria }\end{array}$ & Depende de cada divisão & $\begin{array}{l}\text { Extensivo treinamento em } \\
\text { habilidades especializadas } \\
\text { da organização } \\
\text { Desenvolvimento } \\
\text { contínuo e progressão na } \\
\text { carreira }\end{array}$ \\
\hline $\begin{array}{c}\text { REVISÃO DE } \\
\text { DESEMPENHO }\end{array}$ & $\begin{array}{l}\text { Recompensas para } \\
\text { comportamentos } \\
\text { desejados }\end{array}$ & $\begin{array}{l}\text { Recompensas por } \\
\text { resultados } \\
\text { Análises de curto prazo e } \\
\text { critérios facilmente } \\
\text { mensuráveis }\end{array}$ & $\begin{array}{l}\text { Administração por } \\
\text { objetivos (estratégia } \\
\text { corporativa desce em } \\
\text { cascata até as metas } \\
\text { locais) }\end{array}$ & $\begin{array}{l}\text { Avaliação de desempenho } \\
\text { válida e confiável } \\
\text { Treinamento para } \\
\text { avaliação } \\
\text { Critérios de avaliação são } \\
\text { objetivos e mensuráveis }\end{array}$ \\
\hline $\begin{array}{c}\text { RETENÇÃO } \\
\text { TURNOVER }\end{array}$ & $\begin{array}{l}\text { Seleção externa apenas no } \\
\text { início da carreira elimina } \\
\text { desajustes culturais, } \\
\text { Turnover }<5 \%\end{array}$ & Alto turnover (>25\%) & $\begin{array}{l}\text { Varia de acordo com a } \\
\text { divisão }\end{array}$ & $\begin{array}{l}\text { Turnover entre } 10 \text { e } 15 \% \\
\text { Intenção de manter } \\
\text { aqueles que têm boa } \\
\text { performance e valores }\end{array}$ \\
\hline APRENDIZAGEM & $\begin{array}{l}\text { Forte volume de } \\
\text { conhecimento tácito e de } \\
\text { habilidades funcionais }\end{array}$ & Externalizada & $\begin{array}{l}\text { Forte conhecimento local } \\
\text { Dificuldade de } \\
\text { transferência através das } \\
\text { divisões }\end{array}$ & $\begin{array}{l}\text { Ênfase em aprendizagem } \\
\text { contínua }\end{array}$ \\
\hline Cultura & $\begin{array}{l}\text { Dominante e amplamente } \\
\text { assegurada }\end{array}$ & $\begin{array}{l}\text { Fraca cultura para normas } \\
\text { envolvendo relações com } \\
\text { os outros, as normas para } \\
\text { o trabalho são fortes }\end{array}$ & $\begin{array}{l}\text { Dominante com cultura } \\
\text { corporativa e sub-culturas } \\
\text { divisionais }\end{array}$ & $\begin{array}{l}\text { Cultura forte e dominante } \\
\text { ( normas claras para } \\
\text { relações e trabalho) }\end{array}$ \\
\hline
\end{tabular}

Fonte: Adaptado de Rosseau (1995:184-186)

As organizações defensoras possuem estratégias de manter a participação de mercado e a posição já estabelecidas, as organizações com estratégia prospectora têm características de inovação e procuram constantemente se adaptar às mudanças ambientais, sendo em muitos casos, as primeiras a colocar determinados produtos ou serviços no mercado. As organizações que possuem estratégias de analisadoras se posicionam para responder a diferentes segmentos de mercado e, geralmente, essas 
organizações já atuaram como defensoras e prospectoras em algum momento. Por fim, as companhias com estratégia responsiva operam em ambientes entendidos pela alta administração como mutantes, onde os recursos são vistos como escassos e têm outra característica de destaque que é a redução do ciclo de vida dos produtos e também a redução do time-to-market de seus lançamentos (ROSSEAU, 1995:187-191).

\subsection{Recursos humanos e o aumento das competências e do comprometimento dos funcionários: a criação do capital humano}

No item anterior, foi observada a necessidade da organização realizar um diagnóstico organizacional, sobretudo para avaliar suas competências e capacidades organizacionais e, se for o caso, implementar iniciativas que permitam a adição de valor às competências existentes ou à criação destas. Nesta parte do trabalho, busca-se o entendimento de como a área de recursos humanos pode contribuir para dois aspectos importantes para o conhecimento organizacional: as competências e o comportamento dos funcionários, aspectos inerentes ao seu capital humano.

Como resultado dos trabalhos realizados na seguradora sueca Skandia, Edvinsson e Malone (1998:10) definem o capital intelectual como sendo a soma do capital humano e do capital estrutural. Definem o capital humano como o conhecimento, a experiência, o poder de inovação e as habilidades dos empregados de uma companhia em realizar as tarefas do dia-a-dia; inclui também os valores, a cultura e a filosofia da empresa. O capital estrutural são os equipamentos de informática, os softwares, os bancos de dados, as patentes, as marcas registradas e todo o resto da capacidade organizacional que apoia a produtividade daqueles empregados, ou seja, tudo o que permanece no escritório quando o empregado vai para casa. O capital estrutural também inclui o capital de clientes: o relacionamento desenvolvido com os principais clientes. Como delimitado na introdução deste trabalho, considera-se apenas o conceito referente ao capital humano para que não haja fuga do escopo do trabalho.

Observando-se que a relação das habilidades e competências dos funcionários compõem o capital humano, tem-se o entendimento que “é por meio da aprendizagem que a organização pode desenvolver as competências essenciais ao seu posicionamento estratégico" (OLIVEIRA JUNIOR, 2001:138), desta forma, o processo de aprendizagem organizacional está diretamente ligado à gestão do conhecimento nas 
empresas e à criação de capital humano, sobretudo nos aspectos de aquisição e criação do conhecimento organizacional. Neste ponto parece existir relação com as formas de conversão de conhecimento sugeridas por Nonaka e Takeuchi (1997:68-78): a socialização, a combinação, a externalização e a internalização, todos estes, frutos da inter-relação entre o conhecimento tácito e explícito e destes entre si.

Argyris (1992:112) destaca a existência de dois circuitos de aprendizagem: o circuito simples e o circuito duplo. O circuito simples resolve os problemas visíveis, porém não soluciona a questão primária de porquê os problemas acontecem. A diferença no circuito duplo está em alterar e questionar os pressupostos ou valores fundamentais que governam as ações. A Figura 4.3 mostra os dois circuitos de aprendizagem.

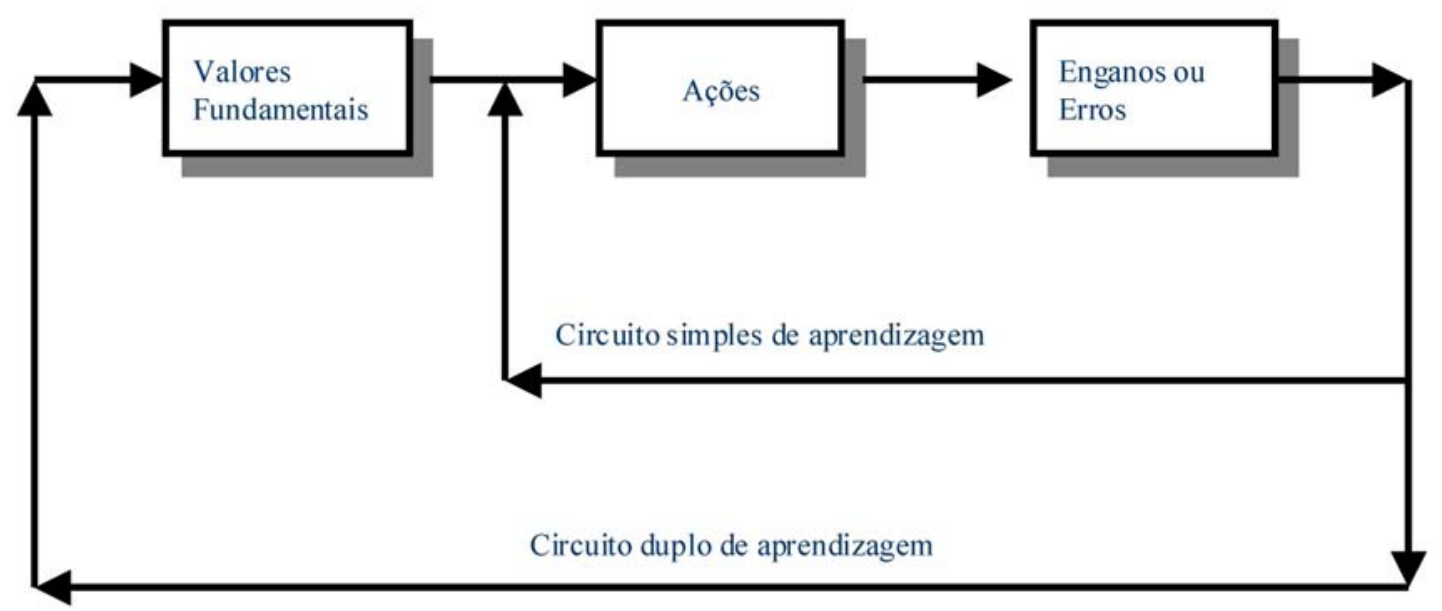

Figura 4.3 Circuito Simples e Circuito Duplo de Aprendizagem Fonte: Argyris (1992:112)

Como se pode observar na Figura 4.3, no circuito simples, um feedback conecta o erro ou engano à sua estratégia de ação. Enquanto isso no circuito duplo de aprendizagem, o feedback liga o erro ao problema detectado à sua estratégia de ação, porém, primeiramente, ligando aos seus valores fundamentais pelos quais as ações são avaliadas e iniciadas.

Para que haja o circuito duplo de aprendizagem, é necessário que os membros da organização desenvolvam a capacidade de criá-lo. Esta capacidade pode ser incentivada pela cultura organizacional adequada que premie ações dessa natureza (ARGYRIS, 1992:112).

A Figura 4.4 contribui para o entendimento do conceito. 


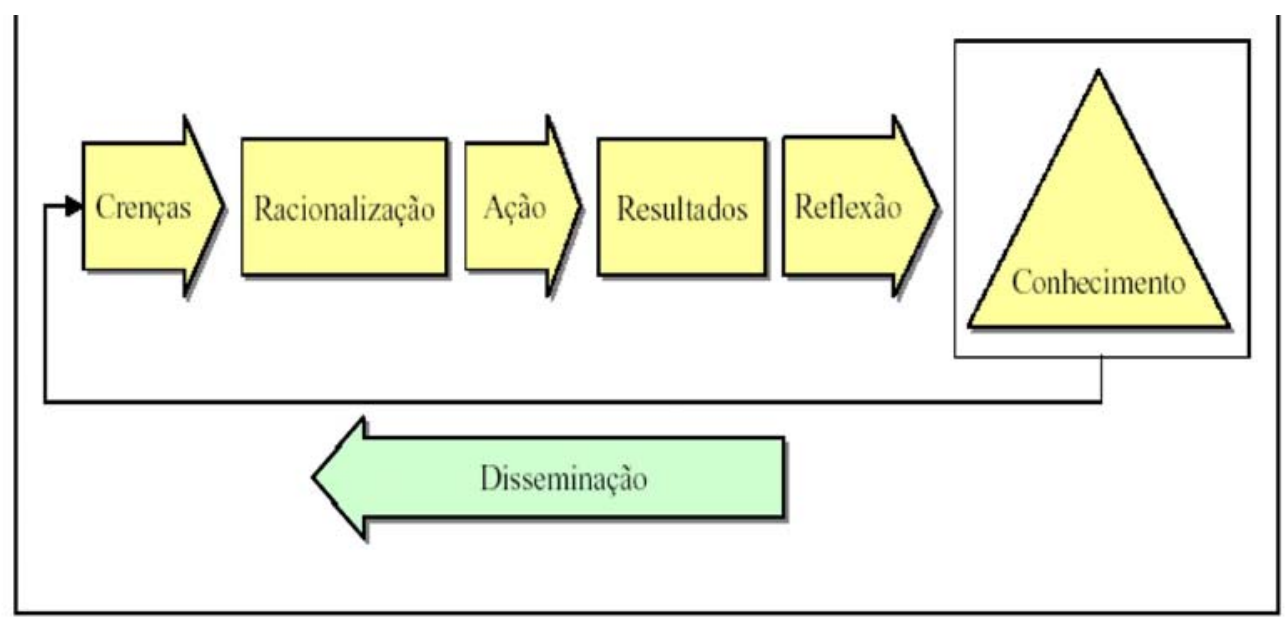

Figura 4.4 Modelo do Processo de Aprendizagem Organizacional Fonte: Amaral (2001:37)

Ulrich (2002:30) sugere que as organizações que aprendem são aquelas capazes de assegurar um rápido aprendizado, incrementando o seu capital humano.

Alguns autores (QUINN, 1996:7-27 e ULRICH, 1998:15-26) procuram sintetizar o capital humano através de uma fórmula bastante simples, considerando-o como sendo o resultado da sinergia entre competências e comprometimento.

A fórmula sugere que o capital humano requer competências e comprometimento dos funcionários e, como a equação envolve uma multiplicação e não uma soma, a contagem baixa de uma ou de outra variável tem impacto direto no montante de capital humano da organização.

Entende-se que não basta apenas à organização ter funcionários talentosos e possuidores de competências necessárias à realização das estratégias empresariais; é necessário, também, que haja comprometimento que é o que permite que as tarefas sejam executadas correta e rapidamente.

Ulrich (2000:21-22) coloca cinco ferramentas básicas para que a gestão de recursos humanos seja orientada para competências, das quais quatro são destacadas: comprar, desenvolver, descartar e reter, as quais são abordadas mais detalhadamente.

Comprar competências significa que os gerentes devem sair da unidade para substituir o talento existente por um de melhor qualidade. Comprar novos talentos traz novas idéias para a empresa, rompe barreiras culturais antigas e cria capital humano, ao mexer nas estruturas da organização. Uma estratégia de compra funciona, mas também 
implica riscos, quando um talento aproveitável está disponível e acessível. Se um talento externo não é claramente melhor qualificado do que um interno, funcionários antigos podem se afastar, ressentindo-se com o funcionário novo que "caiu de páraquedas” na empresa, sem ter passado pelo processo tradicional de promoções internas. Comprar também significa risco, ao integrar um talento diferente em uma equipe inteligente e com bom relacionamento. Em operações que exijam trabalho em equipe, um investimento em pessoas sem espírito de grupo pode não dar certo (ULRICH, 2000:21).

Podemos então relacionar o “comprar” de Ulrich como a atividade funcional de recursos humanos recrutamento e seleção que pode ser, tanto interno quanto externo, dependendo das características e necessidades do momento.

Neste mesmo sentido, concordam Ghoshal e Barlett (2000:86) que a primeira exigência para o desenvolvimento da competência pessoal é a transformação das decisões sobre recrutamento e seleção em decisões estratégicas. Nas empresas que se concentram na competição orientada para o conhecimento, a alta administração reconhece que é possível conquistar vantagem competitiva sustentável, por meio de recrutamento contínuo de pessoas mais qualificadas, motivadas ou inteligentes do que a massa atraída pelos concorrentes.

Também Fleury e Fleury (2000:65) falam em captação de talentos, ou seja, a procura de competências necessárias às estratégias do negócio. As empresas procuram captar pessoas com nível educacional elevado; os programas de trainees são também considerados fundamentais para atrair novos talentos, o chamado "sangue novo”, que não só acena com a possibilidade de renovação futura dos quadros, mas também questiona os procedimentos vigentes com os gestores antigos.

Desenvolver competências significa que os gerentes investem na procura de novas maneiras de realizar o trabalho. Sempre ocorre algum aprendizado durante programas de treinamento formais, porém o desenvolvimento de experiências no trabalho é bem mais proveitoso. Nos dois casos, os gerentes produzem capital humano investindo no aprendizado do funcionário que alia o questionamento à ação, que substitui antigas idéias por outras novas e que muda seu comportamento. O risco de uma estratégia de desenvolvimento está em gastar enormes somas de dinheiro e tempo em um treinamento que se torna um fim em si mesmo e não consegue formar capital humano que gere valor aos negócios (ULRICH, 2000:21). 
Pode-se então, notar que uma atividade funcional de recursos humanos que possibilita a criação de competências e, consecutivamente, de capital humano é o treinamento e desenvolvimento.

De forma objetiva, pode-se situar o treinamento como (MILKOVICH e BOUDREAU, 2000:338): “um processo sistemático para promover a aquisição de habilidades, regras, conceitos ou atitudes que resultem em uma melhoria da adequação entre as características dos empregados e as exigências dos papéis funcionais”. O desenvolvimento (MILKOVICH e BOUDREAU, 2000:338) “é o processo de longo prazo para aperfeiçoar as capacidades e motivações do empregado, a fim de torná-los futuros membros valiosos da organização. O desenvolvimento inclui não apenas o treinamento, mas também a carreira e outras experiências”.

No rastro das transformações organizacionais em andamento, as atividades de treinamento e desenvolvimento se multiplicaram num empreendimento maciço, envolvendo enormes investimentos, à medida que as empresas tentam superar a defasagem entre as capacidades dos recursos humanos e as competências ideais de liderança. Mas as atividades de treinamento tradicionais são limitadas, e como já constatou a maioria das empresas de alto desempenho, esse dispendioso recurso gerencial é mais eficaz quando se concentra na tarefa de desenvolver fatores de competências relacionados com os conhecimentos e experiências já existentes (GHOSHAL e BARLETT, 2000:219).

Entende-se que, quando da realização de algum tipo de treinamento, os gerentes envolvidos devem saber que tipo específico de competência estão querendo desenvolver ou aprimorar, para então, moldar uma forma de treinamento que possibilite resultados reais e que forme capital humano, com destaques para as formas de experimentação prática do trabalho.

Nonaka (1991:68-69) define a importância do treinamento na socialização (conversão do conhecimento tácito em conhecimento tácito) e entende que a socialização é um processo de compartilhamento de experiências e, a partir daí, da criação do conhecimento tácito, como modelos mentais ou habilidades técnicas compartilhadas. Um indivíduo pode adquirir conhecimento tácito diretamente do outro, sem usar a sua linguagem. “Os aprendizes trabalham com seus mestres e aprendem sua arte, não através da linguagem, mas sim através da observação, imitação e prática”. 
Ampliando ainda mais o espectro do treinamento com a transferência do conhecimento tácito - a socialização - Von Krogh et al. (2001:106-107) destacam ferramentas básicas e simples para que isso ocorra, com destaque para:

- observação direta: a observação de como as pessoas fazem as tarefas, entendendo também os pressupostos e crenças arraigados, eficazes ou não, naquelas atividades e processos de trabalho;

- observação direta e narração: simultaneamente à observação direta, as narrativas podem, através de metáforas, se for necessário, explicitar as crenças e valores encravados nos processos e atividades;

- imitação: fazer a tarefa que aprendeu na observação direta;

- execução conjunta: as pessoas tentam, em conjunto, realizar as tarefas e os mais experientes dão orientação aos menos experientes.

Em consonância com o desenvolvimento de competências pode estar a avaliação de desempenho que, quando bem elaborada e seriamente conduzida, pode oferecer marcadores sobre como está o desenvolvimento das habilidades necessárias dentro da organização. As informações sobre desempenho podem servir para quatro propósitos gerais (MILKOVICH e BOUDREAU, 2000:99): devolver informações sobre pontos fortes ou fracos; diferenciar os indivíduos, visando as recompensas; avaliar e manter o sistema de recursos humanos da organização e gerar um arquivo documental para apoiar determinadas ações, como a demissão de um funcionário.

Por fim, Ghoshal e Barlett (2000:270) destacam:

“Ao contrário das máquinas, as pessoas não são propriedades. Todavia, como as máquinas, elas se tornam mais valiosas para as empresas quando se especializam nos negócios e atividades da empresa. Quanto mais específicos os conhecimentos e as habilidades dos empregados para um conjunto exclusivo de clientes, tecnologias, equipamentos e outros fatores da empresa, maior será a produtividade das pessoas e da empresa”.

Descartar competências exige que os gerentes dispensem as pessoas que não desempenhem as suas tarefas satisfatoriamente, de acordo com o padrão estabelecido. Às vezes, isso significa que algumas pessoas, que já foram consideradas qualificadas, 
podem não ter conseguido manter o padrão desejado, de acordo com as habilidades exigidas para as atuais práticas de trabalho. Outras vezes, isto significa dispensar pessoas que sejam incapazes de mudar, aprender e se adaptar. Essa atitude requer coragem, pois decisões difíceis sobre pessoal são tomadas com firmeza. É necessário, também, estabelecer padrões claros em relação a quem fica, quem sai e o que se espera de quem fica. Além disso, deve haver um processo justo e correto para que as exigências legais sejam cumpridas. A prática de descartar ocasiona muitos riscos: ser vista como uma panacéia, perder pessoas erradas, desmoralizar aqueles que ficam, tomar decisões difíceis sobre pessoal baseadas em percepções em vez de em fatos e reduzir a credibilidade da admissão (ULRICH, 2000:22).

Com diversas mudanças nas relações entre empresa e funcionário, sobretudo com a diminuição da estabilidade no emprego e a possibilidade de carreira por toda a vida em uma única organização, muito tem sido reconsiderado nas políticas sobre segurança de emprego na organização.

Muito se tem escrito sobre downsizing que é uma forma de reduzir o escopo das operações e o número de empregados. Esta técnica é muito usada quando a gerência de topo é desafiada a reduzir custos rapidamente e a aumentar a produtividade (SCHERMERHORN JÚNIOR, 1999:173).

Uma outra forma de fazer a prática de descartar competências é através da rotatividade de pessoal, ou seja, em alguns casos pode-se aproveitar determinadas pessoas em outras funções.

Nonaka e Takeuchi (1997:93) vêem, inclusive, benefícios em um "rodízio estratégico" de pessoal, especialmente entre áreas muito diferentes de tecnologia ou funções como pesquisa e desenvolvimento e marketing. Esse rodízio ajuda os membros da organização a compreender sua empresa sob várias perspectivas, tornando o conhecimento organizacional mais fluido e mais fácil de ser colocado em prática. Além disso, permite que cada funcionário diversifique suas habilidades e fontes de informações. As informações adicionais mantidas por indivíduos em diferentes funções ajudam a organização a expandir sua capacidade de criação de conhecimento.

Reter competências significa manter funcionários essenciais para o sucesso da empresa. É também um trabalho de atração baseado na teoria de personalizar contratos de funcionários, estabelecendo uma flexibilidade máxima para retê-los aos projetos que pode ser aplicada aos salários, aos benefícios, ao horário, ao local, aos projetos, às 
expectativas ou às responsabilidades do trabalho - enfim a tudo que posa tornar ou manter atraente a proposta de trabalho para reter um funcionário talentoso. Só pode haver flexibilidade se existirem padrões de rendimento de trabalho bem definidos e se as medidas focalizarem mais os fins do que os meios (ULRICH, 2000:22).

Novamente, pode-se notar, de forma explícita, a relação entre reter talentos e algumas áreas de recursos humanos como remuneração, benefícios, recompensas e até, novamente, a avaliação de desempenho, pois quando um funcionário é corretamente avaliado e reconhecido pelas suas contribuições, se torna mais motivado.

Especificamente quanto à remuneração, algumas tendências na área de recursos humanos têm sido aplicadas, como é o caso da remuneração por competências. Santos (1999:52) afirma que como sistema de remuneração coerente com a gestão estratégica de negócios, “a remuneração por habilidade baseia-se na capacitação profissional dos funcionários da empresa, visando a obtenção tanto das competências essenciais quanto das diversas competências necessárias às empresas neste momento da gestão estratégica de negócio”. Assim, Lawler III* (1981 apud SANTOS,1999:52-53) coloca que neste plano "as pessoas são remuneradas de acordo com o que elas podem fazer, mais do que segundo o que elas realmente fazem. A maioria desses planos remunera o indivíduo de acordo com o número de atividades que ele pode realizar na organização, não considerando somente as atividades que as pessoas estão realizando em determinado momento. Isto leva e enfocar as pessoas mais do que o cargo e as encoraja a adquirir novas habilidades".

No campo de benefícios, muitas iniciativas também têm sido empreendidas para reter as pessoas mais talentosas dentro da empresa. São benefícios do tipo seguro saúde com pagamento completo para o titular e dependentes, previdência privada, bônus e plano de compra de ações da empresa. Neste plano de compra de ações, na maior parte das empresas, a pessoa pode ganhá-lo com base na sua performance e vai recebê-lo depois de um período específico, ou seja, a pessoa ganha a valorização das ações e só pode retirá-las depois de um prazo.

* LAWLER III, E.E. Pay and organization development. Reading: Addison-Wesley, 1981 apud SANTOS, F.C.A. Estratégias de recursos humanos: dimensões competitivas. São Paulo: Atlas, 1999. 


\subsection{Recursos humanos como agente da mudança cultural}

Este item aborda a importância da área de recursos humanos na construção de um ambiente e de uma cultura organizacionais que favoreçam a gestão do conhecimento e a aprendizagem organizacional. O intuito é tentar prover um local em que haja, como defendem Nonaka e Konno (1998:40) e Von Krogh et al. (2001:64), um contexto capacitante apropriadamente preparado para a criação e a troca de conhecimentos. Esse contexto capacitante é uma combinação entre espaço físico, espaço virtual amparado por tecnologia de informação e um espaço mental, sendo, este último, as experiências, as idéias e as emoções compartilhadas.

Na aprendizagem organizacional, Senge (1999:42) destaca a importância da disciplina sugerida de modelos mentais "pressupostos profundamente arraigados, generalizações ou mesmo imagens que influenciam nossa forma de ver o mundo e de agir”. Espera-se que o trabalho com essa disciplina dos modelos mentais possibilite o questionamento desses pressupostos e exista menos resistência às mudanças culturais que podem ser necessárias implementar.

As outras disciplinas propostas por Senge, que já foram também destacadas neste trabalho, têm muita utilidade na construção dessa mudança cultural e precisam ser costuradas por todas as áreas e departamentos da organização, com destaque para a alta administração e recursos humanos, para que possam ser aplicadas, se for o caso.

A mudança cultural mexe com a identidade fundamental, valores e cultura de uma empresa e gera uma mudança profunda, porque esses valores, crenças e premissas profundamente arraigados são contestados e modificados. É uma mudança bastante difícil e o sucesso está relacionado com o grau de maturidade da organização para o assunto (ULRICH, 2002:208).

Desta forma, Ulrich (2002:210-226) destaca cinco passos que refletem a essência do papel da área de recursos humanos no sucesso da mudança cultural:

- definir e esclarecer o conceito de mudança de cultura. Compreender a cultura de uma organização requer discernimento sobre a mentalidade comum dos indivíduos dessa organização. Mentalidade comum representa os pensamentos automáticos comuns entre os indivíduos da organização. O pensamento automático leva os indivíduos a agir e pensar sem ação ou pensamento consciente; 
- formular porque a mudança de cultura é fundamental para o sucesso da empresa. Entender que a cultura organizacional afeta o desempenho da empresa e que, como as impressões digitais, a cultura é única e difícil de ser copiada;

- definir um processo para avaliar a cultura corrente, a cultura futura desejada e a divergência entre as duas;

- identificar abordagens alternativas para gerar mudança de cultura;

- elaborar um plano de ação para implementar e acompanhar a mudança cultural desejada.

O diagnóstico da cultura organizacional também se mostra diferente de acordo com as escolhas estratégicas que a organização fizer (ROSSEAU, 1995:186), como mostrado no Quadro 4.3, e como destacam Fleury e Sampaio (2002:291) no diagnóstico da cultura, "é necessário considerar o contexto em que a organização foi criada e o papel dos fundadores”. Neste aspecto Schneider et al. (1995:748-773) destacam que as metas dos fundadores ou da alta administração resultam na representação de políticas e práticas específicas para que esses objetivos sejam atingidos, fazendo, assim, com que a organização seja caracterizada por estrutura, processos e cultura únicos: "as escolhas dos fundadores ou da alta administração ajudam a construir e manter a cultura organizacional”.

O Quadro 4.4 mostra como as práticas de recursos humanos estão alinhadas com o contexto organizacional, considerando: estratégia, tecnologia e organização do trabalho, ambiente externo e cultura organizacional. 


\section{Quadro 4.4 - Diagnosticando como as Práticas de Recursos Humanos Estão Alinhadas com o Contexto Organizacional: Cinco Fatores.}

\section{ESTRATÉGIA}

- $\quad$ As competências distintivas da organização.

- A base da vantagem competitiva (por exemplo, inovação tecnológica, serviço superior ao cliente, eficiência em produção, linha de produto ou serviço integrada).
- $\quad$ Objetivo de longo prazo (crescimento, participação de mercado, penetração em nichos de mercado).

- Abordagens específicas para alcançar estes objetivos: incluindo estrutura organizacional e financeira.

\section{TECNOLOGIA E ORGANIZAÇÃO DO TRABALHO}

- $\quad$ Arranjo físico / proximidade de trabalhadores.

- Habilidades: adquiridas externamente ou produzidas internamente; específicas ou de fácil cópia.

- Impacto dos trabalhadores na quantidade e qualidade de output; e extensão de como os fatores externos à mensuração da performance do trabalho.
- Necessidade de cooperação e interdependência.

- $\quad$ Necessidade de descrição e criatividade.

- $\quad$ Como empregados e equipes contribuem para a performance da organização: através da conquista de resultados (estrelas); através de evitar desastres (guardiões); através de pequenos incrementos adicionais (soldados); ou um mix de tudo isso.

\section{O AMBIENTE}

- Econômico: trabalho, produção e fatores de mercado.

- Político: expectativas e pressões políticas; política organizacional de empregadores e empregados.

- Legal: responsabilidades da organização, direitos dos empregados; direitos/necessidades para transações com o trabalho organizado.

- Social:

- O que na sociedade dá status aos indivíduos?

- Que tipos de comportamentos são desejados e condenados?

- Quais são as percepções de responsabilidade social da empresa?

- Que tipos de controles organizacionais são (ou não) aceitáveis e legítimos?

CULTURA: O sistema de valores organizacionais tende a enfatizar:

- Confiança ou desconfiança.

- Motivação intrínseca ou explícita e controle.

- $\quad$ Tratamento igual ou diferenciação.

- Centralização ou tomada de decisão local.

- $\quad$ Transparência ou sigilo.

- Cooperação entre empregados ou competição.
- Tradição e estabilidade ou fluxo e mudança.

- $\quad$ Predomínio de grupos ou de indivíduos.

- Meios (processos) ou fins.

- $\quad$ Emprego como troca econômica ou relação social.

- Trabalho ou carreira.

\section{FORÇA DE TRABALHO}

- Demografia: composição com consideração para idade, educação, características e atributos sociais

- Mix ocupacional. (sexo, raça).

Fonte: Adaptado de Baron e Kreps (1999:31). 


\subsection{Gestão de pessoas para a gestão do conhecimento: constatações da literatura}

Neste item, são observadas as constatações que a literatura aborda acerca das iniciativas empregadas em áreas de recursos humanos que, teoricamente, se mostram eficazes para que uma organização consiga gerenciar, efetivamente, os seus recursos do conhecimento. Estas constatações são usadas para orientar o estudo de caso constante nesta dissertação:

- $\quad$ alinhamento total entre as estratégias corporativas e as práticas de recursos humanos. Cada prática de recursos humanos deve tentar responder algum objetivo estratégico (ULRICH, 2002; YEUNG e BERMAN, 1997; ROSSEAU, 1995; TERRA, 1999; SCHULER e JACKSON, 1987; PFEFFER, 1998);

- $\quad$ processo seletivo rigoroso, com opções de contratação interna ou externa na busca de competências e, aceitando a diversidade, as contrações externas consideram a integração que o candidato terá com a organização e não apenas com o cargo (TERRA, 2001; PFEFFER, 1998; VON KROGH et al., 2001; GOSHAL E BARLETT, 2000; ULRICH, 2002);

- quando um novo funcionário é admitido existe um rito de passagem pelo qual este toma conhecimento dos principais aspectos culturais da empresa como valores e normas (NONAKA e TAKEUCHI, 1997; ULRICH, 2002);

- elevado investimento em treinamento, buscando que as pessoas aumentem as suas competências individuais, sobretudo com a possibilidade de observação direta do trabalho e execução conjunta, que seja algo prático também (ULRICH, 2002; MILKOVICH e BOUDREAU, 2000; GOSHAL e BARLETT, 2000; NONAKA, 1991; VON KROGH et al., 2001; TERRA, 1999);

- entendimento para o grupo de que o aprendizado contínuo pode surgir através da prática, a partir da transição de uma rotina conhecida para outra prática nova, através da análise do desempenho com a obtenção de constantes feedbacks, através da contratação de serviços ou de pessoas e a partir de aquisições como transferência de tecnologia (FLEURY e FLEURY, 1997; LEONARD-BARTON, 1995; GARVIN, 1993); 
- $\quad$ também com uso de feedbacks constantes, a organização cria condições para que as pessoas entendam o seu estágio de desenvolvimento atual e, a partir daí, estimula o autoconhecimento para que os funcionários busquem o seu autodesenvolvimento (SENGE, 1999);

- a aquisição de competências individuais direciona parte do salário dos funcionários, sua remuneração é diretamente relacionada com sua performance dentro da organização (TERRA, 1999; ULRICH, 2002; PFEFFER, 1998; GOSHAL e BARLETT, 2000; DRUCKER, 1998);

- processos de avaliação e remuneração vinculados à aptidão e aprendizagem, de tal forma flexíveis, que seja recompensado o talento e não o cargo (GALBRAITH, 1997; DAVENPORT e PRUSAK, 1998);

- plano de carreira que vise reter talentos dentro da organização com possibilidade de promoções internas e claras perspectivas para o futuro (PFEFFER, 1998; TERRA, 1999; ULRICH, 2000, DRUCKER, 1999);

- pacote de benefícios que consigam tanto atrair como reter talentos na empresa (MILKOVICH e BOUDREUAU, 2000; VON KROGH et al. 2001; TERRA, 1999; ULRICH, 2002);

- $\quad$ segurança na manutenção do emprego (PFEFFER, 1998);

- $\quad$ as pessoas têm condições de questionar as práticas usuais observadas nas rotinas de trabalho e sugerir alternativas que visem agregar valor às atividades da empresa, de forma crítica e criativa (SENGE, 1999);

- a missão, a visão e os valores da empresa são conhecidos de todos, porém, não são apenas aceitas, são praticadas de forma profunda e formam uma visão compartilhada (NONAKA e TAKEUCHI, 1997; SENGE, 1999, VON KROGH at al., 2001; COLLINS e PORRAS, 1996; DRUCKER, 1999; LEONARD-BARTON, 1995);

- democratização e ampla divulgação de informações sobre a empresa, em todos os níveis hierárquicos, sejam essas informações boas ou ruins, de ordem interna ou externa (TERRA, 1999; GARVIN, 1993, VON KROGH et al., 2001, NONAKA e TAKEUCHI, 1997);

- a transparência das informações sobre a empresa fornece o todo grupo uma visão do mundo em que vivem, do mundo em que podem viver e o 
conhecimento que a organização deve buscar e criar (VON KROGH et al., 2001);

- $\quad$ a estratégia da organização é de conhecimento de todos (ULRICH, 2002; VON KROGH et al., 2001);

- a visão compartilhada é reforçada através do incentivo ao trabalho em equipes, dando, ao processo de aprendizagem a importância tanto de competências individuais quanto coletivas. Existem também esforços para a criação de grupos de trabalho multidisciplinares, para o entendimento dos problemas organizacionais (SENGE, 1999; NONAKA e TAKEUCHI, 1997; VON KROGH et al., 2001);

- $\quad$ as pessoas são incentivadas a ver a organização não apenas a partir do seu cargo ou departamento, mas observando a empresa como um todo e a importância dessas interações para os resultados globais (SENGE, 1999);

- o contexto em que a organização está inserida gera condições pertinentes ao compartilhamento de conhecimento entre as pessoas, considerando os aspectos do ambiente físico das instalações e também os aspectos relacionados à tecnologia de informação, com o uso de Intranet, correio eletrônico e outras ferramentas, bem como apoio dos sistemas de gestão da organização (VON KROGH et al., 2001; NONAKA e KONNO, 1998; NONAKA e TAKEUCHI, 1997, LEONARD-BARTON, 1995);

- existe um esforço significativo em dar mais autonomia aos funcionários, através do uso do empowerment, por exemplo, e também, em diminuir os níveis hierárquicos (DRUCKER, 1999; NONAKA e TAKEUCHI, 1997; TERRA, 1999; LEONARD-BARTON, 1995; SAVAGE, 1996);

- as transferências internas das melhores práticas que resultaram em sucesso, ou o contrário, são divulgadas para toda a organização (SAVAGE, 1996; GARVIN, 1993);

- aceitação de erros criativos. Não há perda de status por uma tentativa seqüenciada de erro, ao contrário, existe uma solução sistemática de problemas de forma compartilhada, gerando um aprendizado com as próprias experiências (DAVENPORT e PRUSAK, 1998; GARVIN, 1993;LEONARD-BARTON, 1995). 
Neste Capítulo apresenta-se um estudo de caso para suportar a hipótese principal do trabalho de observar como as políticas e práticas de recursos humanos influenciam e facilitam as iniciativas em gestão do conhecimento.

Inicia-se o Capítulo com a metodologia de pesquisa adotada, em seguida uma caracterização do mercado farmacêutico do qual a indústria selecionada faz parte, faz-se também uma caracterização da empresa estudada e por fim analisa-se o projeto em si.

\subsection{Metodologia da pesquisa}

Nesta parte do Capítulo apresenta-se a metodologia empregada na pesquisa e no desenvolvimento das atividades de campo. Destaca-se também a metodologia utilizada para acesso e tratamento de dados e informações.

Inicialmente observa-se a classificação do estudo seguido pelo método de pesquisa adotado, sendo o estudo de caso detalhado para justificativa do método adotado.

Os procedimentos de campo são descritos para o acesso à empresa estudada, o acesso aos dados e às informações, em seguida é dado o tratamento destes dados e informações.

\subsubsection{Classificação do estudo}

A pesquisa de campo que encerra esta dissertação foi realizada através de um estudo de caso para observação do fenômeno e entendimento do problema da pesquisa.

Destaca-se que as respostas e os dados obtidos no estudo de caso são baseados nas percepções dos respondentes sobre os assuntos levantados, bem como fruto de observação e análise de documentos disponibilizados pela empresa. O objetivo principal 
é traçar um paralelo entre as práticas observadas na empresa e os conceitos e tendências descritos na literatura pesquisada.

O estudo é de caráter exploratório e conforme observado por Selltiz et. al (1974) enquadram-se nesta categoria estudos que buscam descobrir idéias e intuições, na tentativa de adquirir maior familiaridade com o fenômeno pesquisado.

Ainda segundo Selltiz et al. (1974), um estudo exploratório possibilita aumentar o conhecimento do pesquisador sobre os fatos, permitindo a formulação mais precisa de problemas, criar novas hipóteses e realizar pesquisas futuras mais estruturadas.

\subsubsection{O método da pesquisa}

De acordo com Godoy (1995a), os estudos nas ciências sociais têm sido tradicionalmente marcados por pesquisas que valorizam os chamados métodos quantitativos na descrição e explicação dos fenômenos estudados. Porém, a autora observa que nos anos noventa foi possível identificar que novas abordagens de pesquisas mais qualitativas têm sido aplicadas em vários estudos acadêmicos, inclusive em administração de empresas.

A autora procura diferenciar os métodos quantitativos dos qualitativos e destaca que num método quantitativo o pesquisador preocupa-se com a medição objetiva e quantificação dos resultados. Busca-se a precisão, evitando distorções na etapa de análise e interpretação dos dados, garantindo uma margem de segurança em relação às inferências obtidas.

De maneira inversa, a pesquisa qualitativa não procura enumerar ou medir os eventos estudados, nem emprega instrumental estatístico na análise dos dados. Parte das questões ou focos de interesses amplos que vão se definindo à medida que o estudo se desenvolve. Envolve a obtenção de dados descritivos sobre pessoas, lugares e processos, procurando compreender os fenômenos segundo a perspectiva dos participantes das situações em estudo.

As pesquisas de natureza qualitativa apresentam, segundo Oliveira (1997), a facilidade de permitir a descrição da complexidade de uma determinada hipótese ou problema, analisar a interação de certas variáveis, compreender e classificar processos dinâmicos vivenciados por grupos sociais, apresentar contribuições nos processos de 
mudanças permitindo a interpretação das particularidades dos comportamentos ou atitudes dos indivíduos.

Godoy (1995a) destaca que quando se trata de pesquisa de caráter exploratório, a investigação utilizando métodos qualitativos parece ser a mais adequada.

Considerando-se o problema a ser estudado nesta pesquisa, adota-se uma abordagem qualitativa, pois, busca-se o entendimento de um fenômeno, no caso, a interação entre a gestão de pessoas e a gestão do conhecimento.

Feita a escolha pela realização da pesquisa utilizando-se uma abordagem qualitativa, tem-se várias possibilidades para a condução de estudos desta natureza. Godoy (1995b) aponta três, bastante conhecidos e utilizados, de pesquisas qualitativas para o tratamento dos fenômenos organizacionais, sendo: a pesquisa documental, a etnografia e o estudo de caso.

\subsubsection{O estudo de caso}

Segundo Godoy (1995a), o estudo de caso se caracteriza como um tipo de pesquisa cujo objeto é uma unidade que se analisa profundamente. Busca um exame detalhado de um ambiente, de um simples sujeito ou de uma situação em particular. Seu propósito fundamental, como tipo de pesquisa, é analisar intensivamente uma dada unidade social e emprega, como técnicas fundamentais de pesquisa, a observação e a entrevista.

Yin (apud CAMPOMAR, 1991) ${ }^{*}$, define que “o estudo de casos é uma forma de se fazer pesquisa social empírica ao investigar-se um fenômeno atual dentro de seu contexto de vida real, onde as fronteiras entre o fenômeno e o contexto não são claramente definidas e na situação em que múltiplas fontes de evidências são utilizadas”.

Complementando a definição, Campomar (1991) destaque que o método científico da pesquisa social empírica permite que se faça levantamento, observação e experimento, fornecendo conhecimento sobre opiniões, atitudes, crenças e percepções dos indivíduos, sejam eles agentes ou pacientes de um processo.

\footnotetext{
* YIN, R.K. Case study research: design and methods. Newbury Park, CA: Sage Publications, 1989 apud CAMPONAR, M.C. Do uso do “estudo de caso” em pesquisa para dissertações e teses em administração. Revista de administração, São Paulo, v.26, n.3, p.95-97, jul./set. 1991.
} 
Três situações, segundo Godoy (1995a), fazem com que o emprego do estudo de caso seja considerado como estratégia preferida dos pesquisadores em determinados casos, são:

- quando procura-se responder às questões “como” e "por quê" certos fenômenos ocorrem;

- quando há pouca possibilidade de controle sobre os eventos estudados;

- quando o foco de interesse é sobre fenômenos atuais, que só poderão ser analisados dentro do contexto de vida real.

Nesta dissertação, justifica-se o uso do método do estudo de caso tendo em vista que procura-se compreender “como” as políticas e práticas relacionadas com a gestão de recursos humanos influenciam e facilitam as iniciativas na área de gestão do conhecimento. Nesta análise não há possibilidade de manipular ou controlar as variáveis estudadas e as considerações são extraídas de um contexto de vida real.

Quando se faz opção por utilizar o método de estudo de caso, há que se atentar para algumas críticas e limitações que se faz a este tipo de estudo.

Sammartino (1995) e Come (2001) colocam que o método do estudo de caso é acusado dos seguintes problemas: falta de rigor nas investigações devido à alta probabilidade de ocorrência de vieses por parte dos investigadores e que o método não permite generalizações, restringindo os resultados da pesquisa somente aos casos estudados.

Para contrapor estas críticas, os mesmos autores, Sammartino (1995) e Come (2001) destacam que vieses e distorções não são características do método empregado e estão relacionados ao empenho do pesquisador, quanto às generalizações é possível fazê-las para proposições teóricas e não para populações ou universos e, ainda, nem sempre a finalidade da investigação científica é a de permitir generalizações.

Em síntese, neste trabalho de natureza exploratória se emprega uma abordagem qualitativa sob a forma de pesquisa bibliográfica e estudo de caso, já que se considera que esta abordagem, dado o exposto, é a que mais possibilita a compreensão de todos os aspectos que o trabalho se propõe a analisar. 


\subsubsection{Seleção do caso para estudo}

O processo de seleção do caso constituiu no seguinte: a partir de contatos com pessoas que exercem a função de gerente de recursos humanos ou responsável pela área de gestão de conhecimento, o pesquisador identificou algumas empresas que poderiam fornecer um caso apropriado para a pesquisa.

Em um segundo momento, o pesquisador retomou o contato com os informantes a fim de obter informações mais detalhadas sobre os casos e pôde então identificar e eliminar aqueles menos favoráveis do ponto de vista de acessibilidade quanto à coleta de dados.

Dentre as possibilidades, foi selecionado o caso ora apresentado por ser este o que reuniu as condições mais favoráveis quanto à viabilidade da pesquisa bem como quanto à exploração dos aspectos teóricos.

Foram utilizados os seguintes critérios para selecionar este caso: facilidade de acesso aos dados, disponibilidade de tempo das pessoas entrevistadas, a melhor relação com a parte teórica deste trabalho e tipo de resultado obtido com o projeto.

\subsubsection{Fontes de dados e de informações e procedimentos de campo}

O uso de múltiplas fontes de dados e de informações é recomendável pois possibilita que se consigam medidas para um mesmo fenômeno reforçando assim a validade da pesquisa (CAMPOMAR, 1991).

Desta forma, a fim de aproveitar tal vantagem foi adotada a idéia de empregar múltiplas fontes de dados e de informações neste estudo de caso: entrevistas abertas com responsável pela área, consulta a documentos e a registros de arquivos, consulta a material eletrônico como Intranet e observação direta informal forneceram os elementos para a construção do caso apresentado.

Como as dados foram coletados em ambiente não controlado, no contexto da vida real, o investigador adaptou seu plano de coleta de dados à disponibilidade dos entrevistados e da organização. Além disso, devido à natureza da problemática não se pôde contar com instrumentos de coleta de dados estruturados, assim foi necessário fazer uso de instrumentos não estruturados. 
O acesso às fontes de dados foi autorizado desde que houvesse o compromisso em se manter o sigilo quanto aos detalhes de características estratégicas do projeto. Não foi autorizada a confecção de cópias de documentos e relatórios de avaliação do projeto estudado.

Dentro da empresa estudada avaliou-se um projeto específico de gestão do conhecimento denominado projeto CLM. É utilizada esta sigla neste trabalho para que haja confidencialidade com a empresa pesquisada. Para o amplo entendimento do projeto foram conduzidas entrevistas com diferentes gerentes da organização.

Os responsáveis pelo projeto entrevistados foram um gerente de recursos humanos e um gerente de tecnologia de informação. Como representante dos usuários foram entrevistados quatro gerentes de diferentes áreas: um gerente de vendas, um gerente de pesquisa clínica, um gerente de produto e um gerente de produção.

Como representante da alta gerência da organização foi entrevistado um diretor de unidade de negócios.

\subsection{Caracterização da empresa}

A empresa estudada forneceu para esta pesquisa uma série de análises para o entendimento prévio do mercado farmacêutico mundial e brasileiro.

O setor produtivo brasileiro que envolve a indústria de produtos farmacêuticos, medicinais e veterinários movimenta anualmente recursos da ordem de US\$ 10 bilhões, sendo hoje a $4^{\mathrm{a}}$ indústria farmacêutica mundial em volume de produção, atrás dos Estados Unidos, França e Itália. O faturamento mundial da indústria farmacêutica já é superior a US\$ 200 bilhões.

Estes setores industriais são atualmente dominados por empresas internacionais, com plantas de produção ou formulação instaladas em diversos países, inclusive no Brasil.

As empresas com capital nacional, responsáveis por cerca de $20 \%$ do faturamento do setor, têm suas atividades centradas principalmente na produção e desenvolvimento de processos, com produtos obtidos por analogia enquanto não havia uma lei de patentes no país, ou com tecnologia transferida por parcerias internacionais mediante participação financeira ou pagamento de "royalties" para as empresas portadoras de patentes. 
Numa análise global, pode-se afirmar que o setor farmacêutico brasileiro está voltado para a farmacotécnica, ou seja, as empresas, principalmente estrangeiras, importam a matéria prima pronta, produzindo no Brasil apenas o medicamento.

Com poucas exceções, não há no país investimento em pesquisa e desenvolvimento de novos produtos neste setor. Porém, o Brasil tem sido importante centro para estudos clínicos de diversos laboratórios farmacêuticos. Estes estudos clínicos fazem parte do desenvolvimento das novas drogas e precedem a fase de lançamento do produto no mercado.

Todas as empresas farmacêuticas mundiais de pesquisa realizam vultosos investimentos em pesquisa e desenvolvimento como parte integrante de sua estratégia competitiva, visando constante lançamento de novos produtos.

A invenção de uma nova molécula é apenas o primeiro passo de um longo processo de pesquisa e desenvolvimento que, cerca de uma década mais tarde, pode vir a resultar no lançamento de um medicamento inovador para salvar vidas ou melhorar a qualidade de vida dos seres humanos. O prazo é longo e os investimentos são igualmente elevados: cerca de US\$ 800 milhões, em média, para o desenvolvimento de apenas um medicamento.

Dessa forma, gastos com pesquisa e desenvolvimento chegam até a $20 \%$ do faturamento das empresas do setor. O potencial de mercado para cada nova droga lançada é conservativamente estimado entre 250 milhões a 1 bilhão de dólares.

A descoberta de novas drogas envolve: alta tecnologia e a conseqüente necessidade de pessoal altamente qualificado para a pesquisa e o desenvolvimento de novos princípios ativos; novas tecnologias como química combinatorial, ensaios de atividade em larga escala robotizados (High-Throughput Screening), planejamento de drogas baseado em estruturas e utilização extensiva da bio-informática estão hoje no topo da agenda dos investimentos.

A adoção da lei de patentes para produtos e processos farmacêuticos e biotecnológicos (Lei 9279 de 14-05-1996) preserva o direito de exclusividade para comercialização de drogas para o descobridor por um período determinado.

A lei de patentes foi motivo de grandes discussões comerciais entre o Brasil e os Estados Unidos até sua promulgação, nos últimos anos o assunto voltou à tona quando o governo do Brasil ameaçou quebrar a patente de produtos para HIV/AIDS. 
Esta lei é considerada pelos laboratórios de pesquisa como ferramenta de suma importância para que novas pesquisas continuem sendo realizadas e novas drogas descobertas.

A empresa identificada para este estudo de caso como já observado pertence ao setor farmacêutico, é uma organização de origem americana e está entre as maiores indústrias do setor. É uma empresa com mais de cem anos de mercado e presente no Brasil há mais de cinqüenta.

A organização estudada é uma das maiores empresas farmacêuticas do mundo. Está presente em 53 países, emprega atualmente 62.000 (dados de 2003 fornecidos pela área de recursos humanos) funcionários, mantém 27 fábricas e seus produtos são comercializados em mais de 200 países e territórios. Seu faturamento anual está por volta de US\$ 20 Bilhões.

No Brasil, segundo a área de recursos humanos, emprega 1312 funcionários (dados de 2003) alocados na unidade fabril que possui e nos escritórios administrativos e de vendas.

A empresa tem, no Brasil, um portfolio de produtos diversificado com marcas consagradas e com atuação em diversas classes de medicamentos para o tratamento de variados tipos de doenças.

Uma das principais características desta empresa é sua orientação para pesquisa. Para o lançamento de novas drogas, os investimentos em pesquisa e desenvolvimento são substanciais, em 2002 foram gastos US\$ 2,9 bilhões na busca de novas moléculas.

Esta postura, orientada para desenvolvimento de novos produtos, pode ser encontrada ao longo de toda a história da organização. A empresa manteve sempre a sua trajetória de crescimento fundamentada na pesquisa e na inovação. Hoje, ela é reconhecida mundialmente como uma das empresas líderes na pesquisa de produtos e serviços farmacêuticos.

Por princípios, considera a descoberta de medicamentos eficazes e a busca de soluções para melhorar tanto a saúde humana quanto a qualidade de vida das pessoas, como parte fundamental de suas efetivas contribuições à sociedade.

O mercado farmacêutico é caracterizado por competição muito forte entre grandes empresas multinacionais. Os investimentos desprendidos para o lançamento de uma nova droga são muito grandes e anos de pesquisa são necessários para que um produto chegue ao mercado. 
O principal objetivo da organização, constante em sua missão, é prover a sociedade com produtos superiores através do desenvolvimento de soluções inovadoras para melhorar a qualidade de vida e satisfazer as necessidades dos consumidores, também se organiza para proporcionar aos seus funcionários um trabalho que seja gratificante e significativo com respeito e oportunidade de desenvolvimento, também ambiciona prover aos seus acionistas taxas de retorno de investimentos superiores.

Os principais valores que a empresa divulga aos seus funcionários são: integridade e altos padrões éticos, respeito ao indivíduo e à diversidade, responsabilidade social, liderança baseada no exemplo, qualidade e produtividade, confiança e transparência, empowerment e trabalho em equipe.

Para atuar neste mercado de grande competitividade com sucesso a empresa julga, como fator primordial e vantagem competitiva, que isso só pode ser atingido se o grupo de funcionários estiver bem motivado e com habilidades acima das comuns.

\subsubsection{A área de recursos humanos no Brasil}

A empresa no Brasil está dividida em unidades de negócios e diretorias que se reportam ao diretor-presidente da subsidiária. A área de recursos humanos é representada através de uma diretoria e com estrutura voltada para a prestação de serviços para todas as outras unidades de negócios ou diretorias.

Os Quadros 5.1 e 5.2 mostram os organogramas da alta administração da empresa e da área de recursos humanos. 

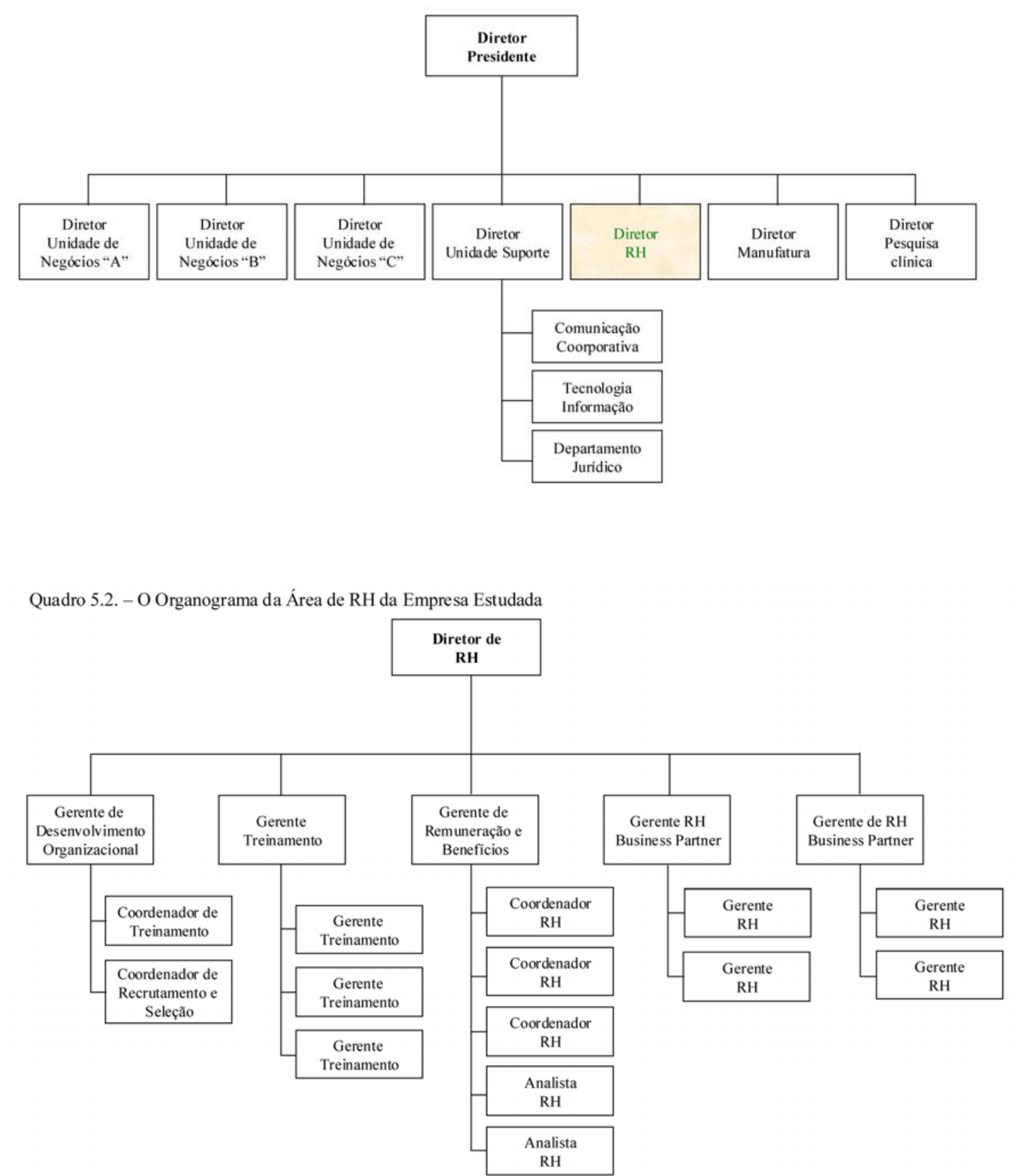

Na organização estudada a área de recursos humanos é vista como parceira dos negócios da empresa. Todas as pessoas que trabalham com recursos humanos têm compreensão da direção que a empresa caminha e seus principais produtos, os demais departamentos da empresa são vistos por recursos humanos como clientes internos.

A área de recursos humanos da organização tem missão própria que é divulgada em diversos locais da empresa. A missão objetiva cultivar um ambiente de trabalho 
estimulante contribuindo com a organização no desenvolvimento das competências do grupo de funcionários, aos quais procura-se oferecer retorno condizente pelo talento e tempo dedicados à empresa.

$\mathrm{Na}$ empresa, a área de recursos humanos tem o entendimento, e o divulga, de que a organização desenvolve as pessoas e, estas ao se desenvolverem, desenvolvem a organização.

As competências são entendidas como sendo "qualquer característica que possa ser observada, medida ou estimada e que diferencie o desempenho superior do desempenho médio". Sendo uma competência composta por conhecimentos, habilidades e atitudes.

Nas visitas à organização é possível notar uma clara diferenciação entre dois aspectos da área de recursos humanos da organização: um focado no operacional e outro focado no estratégico.

O foco operacional visa atender todas as demandas burocráticas que são de responsabilidade da área de recursos humanos. Entre elas pode-se destacar toda a efetivação de procedimentos como folha de pagamento, licenças e férias, relação com sindicatos entre outras.

No foco estratégico o grande desafio da área de recursos humanos é prover todos os gestores das competências necessárias para que estes consigam gerir suas equipes de acordo com a cultura que a empresa adota.

Observa-se que diversos procedimentos que poderiam ser efetuados na área de recursos humanos são feitos diretamente pelo gestor da área interessada. Como por exemplo, um processo de seleção é totalmente conduzido pelo gestor que requisitou a vaga, a gestão de recursos humanos atua como consultoria oferecendo ferramentas e formas para que este gestor chegue aos resultados esperados para aquela posição.

Ainda no exemplo do processo de seleção, a gestão de recursos humanos questiona o requisitante sobre o perfil desejado do candidato e ajuda na definição das competências necessárias para a função. Em seguida é decidido se a contratação será interna ou externa e por fim quais serão os métodos aplicados para a escolha do candidato. A parte operacional é efetivada pelo departamento de recursos humanos.

Todos os gestores da organização são treinados por recursos humanos em diversos assuntos como recrutamento e seleção de candidatos, avaliação de desempenho e outros. 
Algumas observações sobre a área de recursos humanos da empresa estudada:

- nota-se que existe alinhamento entre o objetivo principal da empresa, desenvolver novas drogas efetivas que melhorem a qualidade de vidas das pessoas e as comercializar com sucesso, e a área de recursos humanos. Nas visitas e entrevistas é possível notar que as pessoas de recursos humanos conhecem os produtos e suas estratégias, em alguns casos em detalhes de oportunidades e desafios de mercado;

- a evolução salarial é totalmente ligada à aquisição de novas competências que são observadas através de plano específico de carreira que é desenvolvido por cada funcionário com apoio do seu gestor direto;

- o funcionário tem possibilidade de elaborar seu plano individual de carreira;

- o processo seletivo na organização é bastante rigoroso, podendo ser tanto uma contratação interna quanto externa. São feitos testes e diversas entrevistas com base nas competências desejadas para a função;

- o treinamento é área fundamental da organização, pois existe uma área responsável pelo assunto que esta dentro da diretoria de recursos humanos. Porém, com a exceção de treinamentos corporativos determinados pela matriz americana, quem determina as prioridades de treinamento são os gestores da área requisitante com o suporte dos gerentes de treinamento;

- há definição clara de uma política de reconhecimento às principais contribuições, podendo ou não ser um reconhecimento com premiação monetária;

- a organização tem mecanismos que permitem a divulgação, de forma eletrônica ou por publicações da empresa, das principais contribuições individuais ou das equipes;

- existe uma clara percepção que foi possível observar que a segurança do emprego está totalmente relacionada aos resultados de negócios alcançados;

- a área de recursos humanos faz reuniões constantes entre as unidades de negócios da organização visando estimular a troca de conhecimentos e práticas;

- a avaliação de desempenho é um processo bastante elaborado e dividido em três etapas: elaboração de objetivos, avaliação intermediária e avaliação final; 
- é feito uso constante de feedback inclusive com apoio de ferramenta eletrônica para este fim;

- a aceitação da diversidade é característica marcante da empresa, todos os funcionários, mundialmente, estão passando por um treinamento corporativo sobre o assunto.

Quanto aos benefícios praticados pela organização destacam-se:

- salário acima da média de mercado com possibilidade de ganho variável;

- participação nos resultados ligado à avaliação de desempenho e a aquisição de competências;

- plano de saúde com direito a atendimento médico, hospitalar e odontológico;

- previdência privada;

- $\quad$ seguro de vida;

- bolsa educação, com possibilidade de extensão aos dependentes.

\subsubsection{As iniciativas em gestão do conhecimento}

$\mathrm{Na}$ empresa estudada existem diversas iniciativas em gestão do conhecimento, algumas são corporativas e outras são desenvolvidas por subsidiárias para atender demandas específicas.

É importante e interessante salientar que na organização estudada não existe uma área determinada gestão do conhecimento nem um departamento responsável por todos os projetos de gestão do conhecimento.

O que existe é um conselho formado por profissionais de diversas áreas da empresa para tratar de assuntos referentes à gestão do conhecimento. Dentro da estrutura organizacional não existe uma diretoria responsável para o assunto, mas existe uma diretoria temporária que coordena a ação deste conselho ou comitê. Atualmente o diretor responsável pelo comitê é o mesmo que responde por tecnologia de informação e outras áreas afins.

Este comitê existe tanto na esfera corporativa, na matriz da empresa como em cada subsidiária que tenha interesse em formá-lo. No Brasil, existe desde 2001 e foi implementado nos moldes de outras subsidiárias. 
No Brasil fazem parte deste comitê representantes das seguintes áreas: tecnologia de informação, recursos humanos, qualidade, produção, vendas, marketing, pesquisa clínica e inteligência de mercado.

Segundo os entrevistados o principal objetivo deste comitê, que se reúne ao menos uma vez por mês, não é o de coordenar nenhum projeto ou iniciativa de gestão do conhecimento e sim observar os projetos implementados e avaliar resultados, além de discutir e trocar as melhores práticas entre as áreas da organização e até de outras subsidiárias.

Outro e mais importante objetivo do comitê de gestão do conhecimento da organização é, como afirmam os entrevistados, ser parte fundamental de uma mudança cultural necessária para que a organização se transforme de fato em uma organização com uma cultura voltada para troca e criação de conhecimento.

Os projetos de gestão do conhecimento na organização podem ser classificados em três dimensões: projeto corporativo, projeto regional e projeto local. Um projeto corporativo é desenvolvido pela matriz e implementado por todas as subsidiárias, um projeto regional envolve algumas subsidiárias e sua implementação é decidida em cada subsidiária e um projeto local é desenvolvido em unidades de negócios das subsidiárias para uso apenas no país de origem.

Uma das maiores preocupações do comitê, segundo os entrevistados, é com o volume de informações. Por isso, todos os projetos que, avaliados no comitê, são observados em dois aspectos básicos: o apoio da alta administração e a aceitação do usuário final. Os projetos devem, necessariamente, contar com a aprovação do comitê.

Regularmente são chamados alguns líderes de projetos em gestão de conhecimento para fazer uma exposição de como um projeto foi conduzido e quais os resultados alcançados.

Outra característica de destaque é que nenhum funcionário, ao menos na filial brasileira, se dedica exclusivamente a gestão do conhecimento. Ele pode ser o líder de um projeto, dividir a liderança de um projeto com outro funcionário ou ser um representante de um projeto corporativo, mas sempre tem a sua função principal preservada.

A organização procura criar o reconhecimento, em todos os níveis da hierarquia, do valor do conhecimento para o sucesso dos negócios. E, devido ao tipo de negócio 
que a empresa atua, isso não é novo. Nos laboratórios de pesquisa onde os produtos são desenvolvidos o conhecimento, há anos e anos, é o produto essencial.

Existe uma grande preocupação na geração de um ambiente, onde todas as pessoas da organização se sintam motivadas para aprender, compartilhar e aplicar conhecimento. Este deve ser um dos propósitos mais perseguidos pelo comitê de gestão do conhecimento.

Segundo os entrevistados, a gestão do conhecimento é pautada na utilização de processos que visem localizar, representar, transferir, reter, medir e utilizar de forma sistemática e organizada os conhecimentos estratégicos da organização. Os projetos formais de gestão do conhecimento têm suporte e apoio da área de tecnologia de informação.

Existe também a disponibilização pela organização de ferramentas e práticas para dar suporte às ações descritas acima, que também deve ser avaliada pelo comitê.

Na intenção da organização para o assunto gestão do conhecimento e quando da proposta de um novo projeto são consideradas diversas prerrogativas como compartilhar melhores práticas entre todas as unidades para que as experiências históricas possam ser traçadas.

Outro assunto de destaque é a necessidade de fazer com que o conhecimento percorra as áreas para o qual foi criado, ou para toda a organização, se isso for importante e possível.

Outras considerações importantes sobre as iniciativas e o entendimento da organização para o assunto gestão do conhecimento são observadas abaixo:

- as estratégias de gestão do conhecimento devem estar de alguma forma vinculada à estratégia da organização;

- é necessário fazer acompanhamento constante e mensurar os resultados dos projetos de gestão do conhecimento implementados;

- a gestão do conhecimento é dependente de características culturais e comportamentais da empresa, os princípios e valores, a comunicação e a confiança na organização podem determinar o sucesso de um projeto;

- a tecnologia deve ser a resposta para as necessidades dos usuários e não o gerador de um volume expressivo de informações que não tem valor para o usuário final ou que este não consiga fazer uso correto e constante; 
- $\quad$ os líderes da empresa têm papel primordial no processo de mudança cultural da organização, focando a importância para o conhecimento.

\subsection{O projeto estudado}

A empresa estudada possui diversos projetos em gestão do conhecimento, porém são de caráter estratégico e a organização não disponibiliza para pesquisa.

O projeto estudado disponibilizado pela empresa é aqui denominado de CLM, a idéia do projeto surgiu na matriz corporativa da organização há quatro anos e foi desenvolvido em conjunto pelo departamento de recursos humanos e pelo departamento de tecnologia de informação, ambos da matriz.

Quando a plataforma inicial do projeto já estava pronta foram convocados participantes de diversas subsidiárias da empresa para fazer parte da equipe multidisciplinar que o finalizaria.

Do Brasil participaram três pessoas, dois gerentes de recursos humanos e um gerente de tecnologia de informação. Um dos gerentes de recursos humanos já deixou a organização os outros dois ainda são responsáveis pela condução do projeto CLM no Brasil e foram entrevistados nesta pesquisa.

A idéia do projeto foi gerada quando uma pesquisa mundial feita na organização apontou que ela precisaria fortalecer alguns pontos na sua cultura e nas competências dos seus funcionários para que conseguisse de fato se transformar em uma organização voltada para o conhecimento e que conseguisse criar conhecimento e fazer com que ele fluísse naturalmente sem barreiras por toda empresa.

A partir desta constatação a área de recursos humanos da matriz começou a trabalhar num projeto que valorizasse as competências de liderança da organização.

Essas competências de liderança estão inseridas em quatro grupos:

- competências individuais para autodesenvolvimento;

- competências individuais relacionadas ao negócio da empresa;

- competências individuais de desenvolvimento de pessoas;

- $\quad$ competências de comunicação.

A Figura 5.1 mostra a plataforma que dá base ao projeto CLM. 


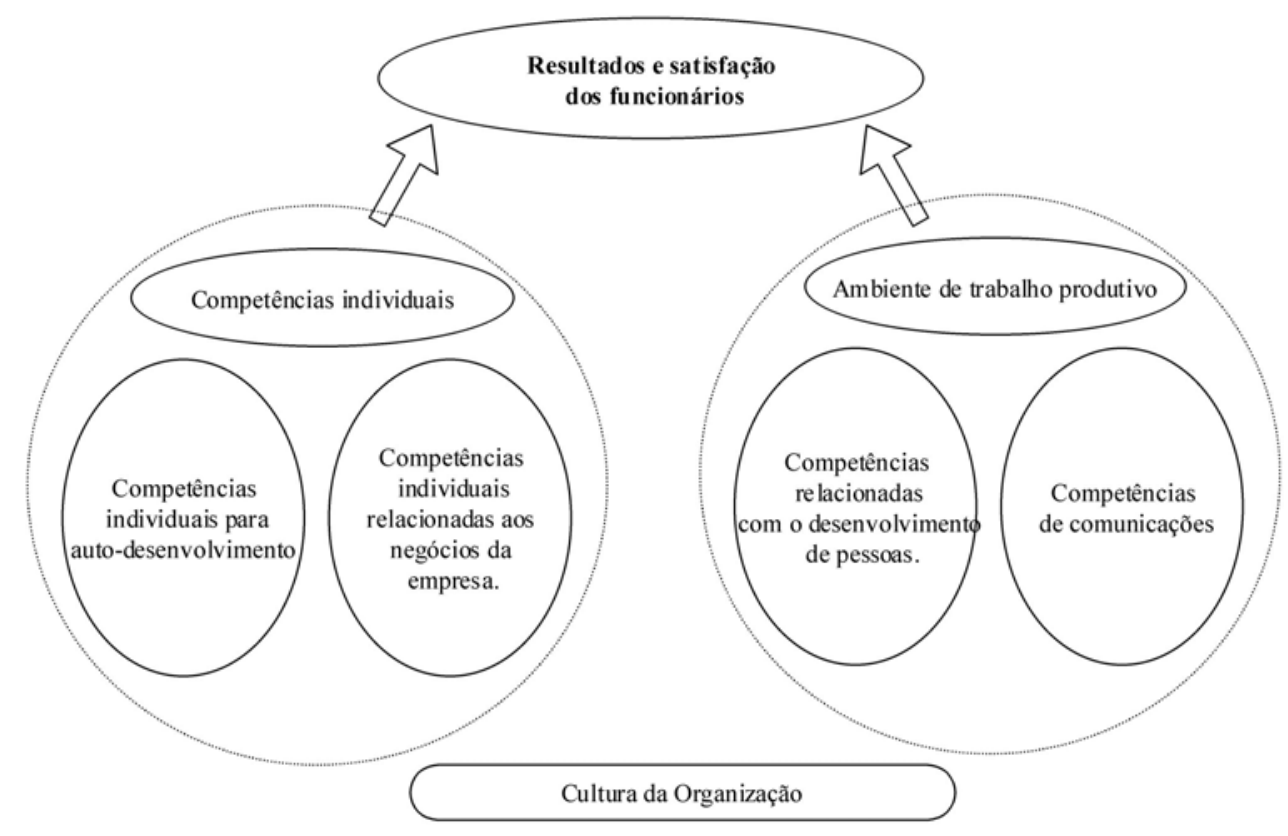

Figura 5.1. - Plataforma do Projeto CLM

Dentro de cada grupo principal de competência existe um aprofundamento maior dos comportamentos e competências que, de acordo com a organização, são fundamentais para que o ambiente organizacional suporte as iniciativas de gestão do conhecimento.

Os dois primeiros grupos (competências individuais de autodesenvolvimento e relacionadas aos negócios) tratam das competências e comportamentos individuais de cada funcionário, as quais são mais valorizadas e importantes para as estratégias da organização.

Os dois últimos grupos (competências de desenvolvimento de pessoas e comunicação) tratam de competências e comportamentos considerados importantes para a criação de um ambiente de trabalho produtivo.

Essa matriz de competências é de conhecimento de todos os funcionários da organização, pois em toda avaliação de desempenho estas competências e comportamentos são considerados e determinam o nível de liderança e comprometimento de cada funcionário.

Segundo os entrevistados, esta matriz de competência é um dos maiores símbolos que a organização tem, vem sendo desenvolvido ao longo dos anos, mas a sua base são os valores e princípios da organização. 
Para que a cultura fosse de fato mais fortemente voltada para o conhecimento e a matriz de competências e comportamentos da organização já dispunha de muitas características sobre o assunto, decidiu-se por fazer uso desta ferramenta de forma mais intensa.

Para isso foi criado um portal na página da Intranet da empresa, com o objetivo de que a área de recursos humanos possa contribuir para fortalecer esta cultura voltada para o conhecimento, aplicando ferramentas de gestão do conhecimento.

O acesso é restrito aos funcionários que, para usarem o portal, devem inserir sua senha eletrônica. Foi-nos possibilitado alguns acessos acompanhados para que um entendimento maior pudesse acontecer, a seguir um detalhamento do projeto CLM.

\subsubsection{O que é o projeto CLM?}

Tendo-se a matriz de competências e comportamentos criou-se o portal na página da Intranet. O principal objetivo do CLM é a troca de conhecimento sobre esta matriz de competências e comportamentos.

O usuário ao acessar o CLM tem duas opções principais de escolha: recursos ou contribuição.

No que diz respeito aos recursos são mostrados todos os itens que a organização tem que possam facilitar o treinamento do funcionário para que este desenvolva o comportamento ou competência que esta pesquisando no portal.

O usuário pode escolher entre um dos quatro grupos de competências ou comportamentos, em seguida coloca qual nível tem dentro da hierarquia. Neste item os níveis são apenas três: executivo, gerente ou diretor e usuário independente. Por fim escolhe que recursos está procurando, estes recursos podem ser:

- treinamento formal no trabalho;

- $\quad$ recurso de aprendizagem na web;

- $\quad$ artigos, livros ou mídia eletrônica;

- ferramentas.

Abaixo relata-se um exemplo prático do uso na possibilidade de acesso concedida a este pesquisador.

Escolheu-se o grupo de competências individuais relacionadas aos negócios da empresa. Dentro deste grupo, escolheu-se uma competência denominada “compartilhar 
conhecimento com os outros” e colocou-se o nível de gerente ou diretor devido ao entrevistado que acompanhava o acesso e foram solicitados todos os recursos disponíveis conforme os listados acima.

Os resultados obtidos foram os seguintes:

- no recurso de treinamento formal no trabalho, foram disponibilizados três workshops: um sobre transferência de conhecimento, um sobre tomada de decisão e o último sobre solução de problemas. Em cada workshop existia uma breve descrição do que era o programa, quais os objetivos principais e qual o público alvo, em alguns haviam critérios para inclusão no treinamento como nível dentro da hierarquia;

- no recurso aprendizagem na web, a busca resultou em um curso específico sobre fixação de objetivos, na definição do curso foi possível notar que se dava a importância para que todos que acessassem entendessem os principais fundamentos da gestão do conhecimento e os inserisse dentro do possível nos seus objetivos pessoais. Não foi permitido acessar o curso, porém, no caso deste curso na web qualquer funcionário pode usá-lo;

- no recurso artigos, livros ou mídia eletrônica foram disponibilizados diversos itens que qualquer funcionário pode requerer como livros, artigos eletrônicos, fitas de vídeo e áudio entre outros;

- o último recurso ferramentas é um espaço onde são feitas as contribuições de cada pessoa. Uma contribuição é aceita quando é validada pelos responsáveis locais do programa. No caso da subsidiária ou se for de acesso global, a contribuição necessita de aprovação da área de recursos humanos da matriz.

No acesso surgiu uma ferramenta denominada "Planejamento da performance da equipe” o sumário desta ferramenta mostrava que era de origem americana e constava o nome e cargo do funcionário que a criou. $\mathrm{O}$ item ainda especificava que era de acesso exclusivo a gerentes de um determinado nível e que o documento era restrito.

A outra forma de acesso que todo funcionário pode fazer é no ícone contribuição. Nesta página o funcionário escolhe a competência e ou comportamento desejado e uma outra página se abre para que faça sua contribuição. 
Toda contribuição é automaticamente enviada para os responsáveis do projeto que fazem uma avaliação inicial da procedência e utilidade. Sendo considerada inicialmente válida já passa a fazer parte da Intranet da subsidiária e é enviada para a diretoria de recursos humanos local e posteriormente decidido se será enviado para a matriz.

Segundo os entrevistados, diversas contribuições já fazem parte do projeto CLM na subsidiária do Brasil. Algumas destas foram enviadas e aceitas para uso mundial.

Os principais exemplos de sucesso são divulgados para toda organização, recentemente houve um reconhecimento formal a um funcionário que colocou uma contribuição sobre um cliente, a contribuição foi aceita e o impacto para as outras áreas foi muito significativo.

No portal ainda é possível que cada usuário monte um planejamento das competências que deseja desenvolver para os próximos períodos, podendo solicitar recursos extras aos especialistas cadastrados e agendar seus treinamentos.

Nas duas áreas que o modelo de competências contempla, competências individuais e construção de um ambiente de trabalho produtivo, existem diversos comportamentos que são desejados e observados nos funcionários.

Segundo os responsáveis pelo projeto CLM no Brasil e que fizeram parte do desenvolvimento do projeto mundial, o acesso não é obrigatório, porém cada gestor tem um relatório de quais funcionários da sua equipe estão utilizando o projeto.

As contribuições não são premiadas em dinheiro, porém existe um reconhecimento formal àquelas mais significativas.

Para um universo de mais de 1300 funcionários na subsidiária do Brasil, o projeto conta com aproximadamente 450 usuários assíduos após pouco mais de um ano de disponibilização. Segundo os responsáveis, os números apontam que o acesso no Brasil tem sido acima da média de outras subsidiárias.

\subsubsection{A percepção do projeto CLM pelos usuários}


Como já destacado, foram considerados, como usuários e como representantes dos usuários, quatro gerentes de diferentes áreas da organização:

- um gerente de produção responsável especificamente sobre importação e exportação de matéria-prima que lidera uma equipe com doze subordinados diretos;

- um gerente de produto ligado à área de marketing responsável por um produto chave da empresa com faturamento anual na ordem de $\mathrm{R} \$ 30$ milhões, este gerente conta com oito pessoas que se subordinam a ele em áreas diferentes;

- o outro gerente estudado é da área de pesquisa clínica, este gerente tem nove subordinados que são coordenadores de pesquisa clínica e são responsáveis pelo contanto entre a empresa e centros de pesquisa;

- o último gerente entrevistado é da área de vendas e tem nove representantes de vendas que se subordinam diretamente a ele.

As considerações são colocadas de forma geral observando as características que são contempladas mais freqüentemente, em alguns casos específicos é feita menção à área.

Nas entrevistas com os gerentes fica claro, de início, que todos são favoráveis ao projeto CLM, sendo fácil observar a aceitação no nível gerencial. Com as entrevistas concluídas, foi possível observar o porquê desta aceitação e os pontos de melhoria apontados.

Quando se questiona a aceitação dos funcionários ao projeto CLM, também foi possível observar pontos em que as considerações são iguais com os quatro gerentes entrevistados.

Aliás, um ponto de destaque nas entrevistas com os gerentes é quanto a aceitação do projeto. Três dos quatro gerentes entrevistados estão na empresa desde o início do projeto e puderam acompanhar todas as etapas de desenvolvimento.

O gerente de produção e o gerente de vendas participaram de um time multidisciplinar que discutiu as primeiras percepções dos funcionários sobre o primeiro contato com o projeto.

Todos os gerentes entrevistados têm a percepção de que o projeto foi muito cauteloso desde o início e o uso de algumas pesquisas formais com funcionários 
escolhidos aleatoriamente foi imprescindível para o sucesso inicial da disponibilização do projeto CLM para a subsidiária Brasil.

De acordo com os gerentes entrevistados a cultura da organização reforçada em todos os níveis gerenciais através dos seus princípios e valores, tem sido fator chave para a aceitação de diversos projetos em gestão do conhecimento. Essa cultura, segundo os gerentes, tem sido mais intensa depois da implementação do CLM.

O fato de os gerentes entenderem que a cultura da empresa tem sido cada vez mais orientada para o conhecimento e que os valores praticados e a característica do negócio da organização faz com que o conhecimento seja entendido por todo o grupo como fator primordial para o sucesso nos negócios.

Não existiu, na implementação do projeto CLM, nenhuma barreira cultural significativa em que as pessoas mostraram resistência que pudesse bloquear o projeto.

Isto também se deveu ao fato de que o contexto em que o projeto foi implementado já terem ocorrido diversos outros projetos em gestão do conhecimento e, segundo os gerentes, muitos problemas que poderiam fazer com que surgissem barreiras culturais ao CLM já estavam eliminados.

Quando perguntados sobre quais poderiam ser estes possíveis problemas que poderiam acarretar barreiras culturais, os gerentes apontam para pessoas resistentes em diversos níveis da hierarquia organizacional que já haviam deixado a empresa. Algumas destas pessoas ocupavam cargos gerenciais e exerciam liderança negativa e chegaram a por em condições desconfortáveis a implementação de alguns projetos de gestão do conhecimento.

Todos acreditam que os principais focos de barreiras, inclusive provenientes da estrutura organizacional, já foram eliminados e o projeto CLM especificamente não foi implementado neste período e sim em uma época em que o nível gerencial é considerado mais “maduro”.

Os gerentes se declaram usuários do projeto, alguns até mostraram evidências de que de fato o utilizam com freqüência.

Quanto à utilização por parte dos funcionários, há uma clara observação que é feita por todos os gerentes. A organização tem características de grande competitividade interna, os gerentes consideram que a grande maioria dos funcionários são pessoas de alto potencial. 
Os gerentes fazem o diagnóstico de que o uso do projeto está totalmente relacionado com a motivação das pessoas com a empresa como um todo. Sobretudo pelas fortes características da cultura exclusiva que o projeto prega.

No projeto, como já destacado, são valorizados os comportamentos que criam ambientes que propiciam a construção das competências-chave para os negócios da organização. A possibilidade de poder aprender com o projeto através do uso da Intranet é visto de forma muito positiva pelos funcionários. Porém, os que de fato utilizam o projeto são aqueles que estão em um momento de alta motivação com a organização ou com sua carreira.

Os gerentes observam que aqueles funcionários de alta performance, que têm condições de fazer carreira dentro da organização, são os que mais assiduamente utilizam o projeto.

Todos os gerentes afirmam que incentivam todos os funcionários a usarem o projeto e extraírem o máximo de conhecimento possível e, também, contribuírem quando julgarem importante.

O fato de um funcionário poder contribuir com seu conhecimento resulta em visibilidade na organização para as pessoas que fazem contribuições efetivas.

Nos primeiros meses de implementação do projeto isto foi ponto crítico, pois algumas pessoas começaram a fazer contribuições desnecessárias ou com grande quantidade de dados e informações, que não chegavam a trazer uma contribuição efetiva, nem conhecimento que pudesse ser utilizado em outra parte da organização.

Foi necessária uma correção de conceitos e os gerentes tiveram que ser muito cuidadosos para não criar inibição nos funcionários em alimentar conhecimento no CLM e nem em instituir um filtro de triagem gerencial para saber quais os inputs que estavam sendo colocados no projeto, segundo os gerentes este foi um momento crucial para o andamento do CLM no Brasil.

Outro grupo de funcionários que usa freqüentemente o CLM é aquele formado por pessoas altamente comprometidas com a organização. São pessoas de alta performance que não têm interesse em entrar na competitividade interna, estão satisfeitas nas suas posições atuais e executam seu trabalho com qualidade e profissionalismo.

De acordo com os gerentes, neste grupo de pessoas, o uso do CLM se dá de maneira bastante efetiva, eles acreditam que isto ocorre porque estas pessoas gostam do 
que fazem e trabalham engajadas com a organização e têm prazer em fazer parte do grupo.

Um terceiro grupo de usuários definido pelos gerentes inclui as pessoas de baixa performance ou que não estão motivadas com a organização.

Segundo os gerentes, não é muito freqüente, entretanto, existem casos de um funcionário ser considerado competitivo e ter condições de seguir carreira e em seguida apresentar resultados abaixo da expectativa. Acredita-se que isto ocorra pelo fato de nem sempre a organização conseguir suportar e dar oportunidades para as pessoas com características competitivas semelhantes.

O Quadro 5.3 mostra um resumo dos três perfis de funcionários e o uso do CLM. Quadro 5.3: Utilização do CLM

\begin{tabular}{|l|l|l|l|}
\hline \multicolumn{1}{|c|}{$\begin{array}{c}\text { Classificação dos } \\
\text { funcionários }\end{array}$} & Nível de motivação & Característica principal & \multicolumn{1}{|c|}{ Uso do CLM } \\
\hline Competitivos & Altamente motivados & $\begin{array}{l}\text { Têm interesse em seguir } \\
\text { carreira na organização. }\end{array}$ & Freqüente. \\
\hline Alta performance & Motivados & $\begin{array}{l}\text { Executam o trabalho com } \\
\text { profissionalismo e de } \\
\text { forma efetiva. }\end{array}$ & Freqüente e efetivo. \\
\hline Baixa performance & Desmotivados & $\begin{array}{l}\text { Não se integram à à } \\
\text { organização. } \\
\text { Estão desiludidos por já } \\
\text { terem sido considerados }\end{array}$ & $\begin{array}{l}\text { Nãilizam com } \\
\text { efetividade. }\end{array}$ \\
\hline
\end{tabular}

Os gerentes acreditam que a gestão de recursos humanos da organização está voltada para fazer com que as pessoas se sintam motivadas com a empresa, eles mesmos sabem que seus papéis enquanto líderes é preponderante para que as mudanças sejam entendidas, aceitas e praticadas.

O fato de as pessoas saírem de um patamar de classificação de competitivo para baixa performance é visto com cautela e todos os casos são observados e discutidos em reuniões gerenciais com os gerentes da mesma área. Os processos justos e coerentes com os valores e princípios da organização são a principal resposta para que isso não aconteça.

Quanto ao impacto que o CLM exerce no trabalho diário das pessoas, os gerentes observam que no grupo que o utiliza com freqüência isto é facilmente identificável. 
As avaliações de desempenho realizadas fazem parte de um processo formal e obrigatório na organização e contempla as seguintes etapas:

- estabelecimento de objetivos: os objetivos são estabelecidos pelos subordinados e discutidos com o superior imediato, os objetivos precisam estar em linha com os objetivos da subsidiária;

- revisão intermediária: no meio do ano subordinado e superior sentam para discutir como estão os objetivos até o momento. Nesta mesma oportunidade o superior discute os feedbacks que os stakeholders forneceram sobre o funcionário avaliado;

- revisão final: no final do ano é feita a revisão final em que os objetivos são novamente avaliados e encerrados. Neste momento também e feita a apresentação do bônus e feedback final. Os bônus são oferecidos com base na contribuição do funcionário e das competências desenvolvidas.

Todas estas etapas apontadas são determinadas seguindo-se o modelo de competências e comportamento que o projeto CLM contempla. Segundo os gerentes, é possível observar com clareza, naquelas pessoas que fazem uso com freqüência do projeto CLM, uma consistência maior quanto às competências observadas do que naqueles que não usam o projeto.

Os gerentes têm acesso a um relatório que aponta o uso do CLM, neste relatório, que foi disponibilizado para o pesquisador para observação, consta uma estatística do uso do projeto por parte de cada subordinado do gerente.

Todos os gerentes afirmam com veemência que não fazem uso deste relatório para "forçar" os seus subordinados a fazerem uso do CLM. Também afirmam que seus superiores não o fazem.

Também é sempre destacado pelo gerente que o uso ou não do projeto não interfere na avaliação de desempenho de cada funcionário.

Quando perguntados como fazem para manter seus funcionários motivados a utilizarem o projeto, é possível observar que as respostas não são uniformes e, de forma geral os gerentes observam que o projeto CLM é “vendido” a todos os funcionários como uma forma que eles têm de aprender sobre as competências e comportamentos mais importantes para a organização e também mostrarem as suas competências sempre de forma voluntária sem obrigatoriedade. 
Por fim observam-se os principais pontos positivos e os pontos de melhoria do projeto CLM:

- implementação inicial considerou a opinião do usuário;

- $\quad$ ligação e responsabilidade do projeto por parte de recursos humanos;

- tecnologia simples e de domínio de todos;

- $\quad$ não obrigatoriedade de uso;

- possibilidade de aumentar as competências que são valorizadas na organização;

- valorização e publicação das contribuições mais importantes;

- integração do projeto com o trabalho diário das pessoas;

- $\quad$ possibilidade de planejamento da carreira com base em competências;

- $\quad$ a comunicação é sempre clara no que se refere ao projeto;

- $\quad$ apoio da alta administração.

Quanto aos pontos de melhoria o principal destaque em todos os entrevistados é o fator tempo. Todos alegam, inclusive os próprios gerentes que a organização já conta com diversos processos obrigatórios que tomam muito tempo dos funcionários. O fato de a empresa ser orientada para processos também é ponto suscetível do projeto, pois muitos temem que possa estar “nascendo” mais um processo obrigatório.

No caso do gerente de vendas entrevistado, o problema tempo é mais acentuado do que nos outros, e alega que devido a este fato a adesão na sua equipe e em toda força de vendas não é grande.

Quanto ao caso específico da área de vendas da empresa, o gerente entrevistado comentou que a adesão é menor do que em outras áreas da empresa por outros motivos já conhecidos na organização.

A organização tem o histórico de um processo de informatização da força de vendas, com ferramentas de gestão do conhecimento, que não foi bem aceito pelos funcionários, como se tratava de um projeto desenvolvido por algumas subsidiárias da empresa não foi possível abortá-lo e até os dias atuais é utilizado com críticas pelas pessoas que trabalham nesta área.

O gerente de vendas informou ainda que muito se aprendeu e se aprimorou na informatização da força de vendas e hoje o projeto é mais simples do que no início, 
porém, segundo ele, os funcionários ainda não conseguem extrair conhecimento útil do programa e tem a obrigatoriedade de alimentar dados diariamente.

Outro ponto de cuidado para o projeto que é levantado pelos gerentes é quanto à sobrecarga de informações não do projeto CLM, mas da organização como um todo, eles comentam que nem tudo é aproveitado como deveria.

\subsubsection{A percepção do projeto pela alta administração}

Como já mencionado, para representar a alta administração da organização foi possível entrevistar um diretor de unidade de negócios. Antes de falar sobre o projeto CLM, o diretor quis abordar especificamente qual a visão da alta administração sobre as iniciativas em gestão do conhecimento como um todo.

Segundo o diretor entrevistado, a gestão do conhecimento na organização procura sempre atender algum ponto da estratégia do negócio. Acredita que um importante fator de sucesso para os programas de gestão do conhecimento é a sua relação direta com a estratégia do negócio e com processos de negócios essenciais, visando sempre a ligação com o cliente externo.

Na entrevista com este diretor fica muito clara a importância dada pela alta administração da empresa para que os princípios e valores sejam amplamente divulgados e praticados por toda a organização. Esse fortalecimento da cultura por parte da alta administração é visto como elemento de sucesso para projetos de gestão do conhecimento já implementados.

Alguns esforços têm sido freqüentes na organização para a criação de um ambiente propício à troca de conhecimento e seu posterior fluxo por toda a empresa. $\mathrm{O}$ diretor destaca que, nos últimos anos, todos os funcionários colocaram entre seus objetivos para avaliação de desempenho um item que estimulasse as pessoas a falar e expor francamente as suas percepções e opiniões sem risco de retaliações.

Esta conduta é defendida em todos os níveis da empresa por todos os funcionários com cargo gerencial, partindo do diretor presidente da organização.

Uma grande preocupação da alta administração é manter o grupo de funcionários motivados para compartilhar conhecimento e algumas iniciativas são destacadas para este fim:

- $\quad$ a comunicação das metas da empresa é feita de forma transparente e regular; 
- a divulgação dos benefícios que compartilhar conhecimento podem acarretar também é divulgado para toda a empresa;

- $\quad$ histórias de sucesso e soluções inteligentes também são reconhecidas;

- $\quad$ existe estímulo para que pessoas de áreas diferentes mantenham diálogo constante;

- $\quad$ existe a formação de diversos grupos de trabalhos multidisciplinares.

Outro aspecto destacado pela alta administração é a concepção que de prestação de serviços, as áreas principais da empresa que determinam o seu desempenho no mercado contam com áreas de suporte e fornecimento de informações e conhecimento.

O papel da tecnologia não pode ser superior às condições culturais da organização. Segundo o diretor entrevistado, o sucesso das iniciativas em gestão do conhecimento está totalmente relacionado com os esforços e investimentos em tecnologia de informação, porém isto deve ser considerado sempre após as observações de como um projeto será aceito e utilizado.

A alta administração está imbuída para que a cultura da empresa esteja cada vez mais orientada para o conhecimento, em que compartilhar e a criar conhecimento de forma coletiva devem ser parte do trabalho diário de todos os funcionários.

Em síntese, a visão da alta gerência sobre o sucesso das iniciativas em gestão do conhecimento destaca três passos:

- determinar que tipo de conhecimento é crítico e útil para os negócios e como pode suportar a estratégia da organização;

- identificar onde este conhecimento pode ser criado, quando é mais útil e possível compartilhá-lo e como isso pode ser feito dentro do contexto organizacional;

- o processo de gestão do conhecimento deve estar definido como uma parte dos processos de negócios da empresa.

Quanto ao projeto CLM especificamente, segundo o diretor entrevistado, foi uma forma encontrada para divulgar e incentivar que os princípios de liderança da organização, composto por comportamentos e competências, fossem melhor compreendidos, praticados e inseridos no trabalho diário dos funcionários, fortalecendo assim a cultura corporativa da organização. 
A subsidiária do Brasil segue o padrão corporativo em diversos processos estabelecidos pela matriz americana, porém há a possibilidade de fazer algumas adaptações em projetos específicos ou de não implementar algumas ferramentas.

No caso do projeto avaliado segue-se na íntegra o que foi construído pela matriz, mas segundo o diretor entrevistado, o fato de ter-se na subsidiária pessoas que estiveram envolvidas na construção e manutenção do projeto global, fica possível perceber que o projeto é totalmente aplicável à realidade brasileira.

Todos os comportamentos e competências que estão definidos no modelo adotado no CLM são úteis aos negócios da empresa e de alguma forma procuram contemplar a estratégia corporativa da empresa, sendo o projeto apoiado totalmente pela alta administração da subsidiária Brasil.

Segundo o diretor entrevistado, o projeto CLM é divulgado e incentivado em todas as oportunidades possíveis na organização dado seu caráter estratégico. No seu caso específico, procura estimular todos os gerentes que se reportam diretamente a ele para que usem e compartilhem os seus conhecimentos no CLM. Incentiva muito que isso aconteça com os subordinados dos seus subordinados e afirma que isso acontece em cascata, sendo ele também incentivado por seus diretores no Brasil e no exterior.

O entrevistado se declara usuário assíduo do CLM e destaca que o uso deve ser totalmente voluntário e que não há mecanismo formal nenhum que premie o uso. Segundo ele, a concepção do projeto prevê que o benefício do uso deva ser percebido pelo funcionário e acredita que, pelas características culturais da empresa e do projeto, isto é totalmente factível e uma questão de maturidade do projeto.

A alta administração acredita que tornar o uso ou acesso premiável pode mascarar a real utilidade das informação disponibilizadas no CLM e afirma que o uso deve ser conseqüência da motivação do grupo para com o projeto.

O diretor tem conhecimento das estatísticas de acesso ao CLM e as utiliza em suas reuniões com seus subordinados, porém percebe mais validade nos feedbacks que recebe diretamente de algumas pessoas que utilizam o projeto.

Na opinião do diretor, o principal problema encontrado para uso do projeto é o tempo. Muitos funcionários alegam não terem tempo para fazer uso do projeto e compartilhar conhecimento, alguns até afirmam que utilizam o CLM e conseguem extrair algo de validade, porém pela falta de tempo não alimentam o projeto com seus próprios conhecimentos. 
Segundo o diretor, este é o principal ponto de atenção para com o CLM, comenta que já foi mais crítico na implementação, mas ainda segue sendo o ponto de observação e melhoria mais incisivo.

A sua posição a respeito do fator tempo é de entendimento e compreensão. Ele acredita que, em determinados períodos, grupos de funcionários estejam sobrecarregados com outros processos obrigatórios, porém percebe que este fator não pode ser a "bengala” para todas as situações. Por isso, estimula o seu grupo gerencial a "vender" o projeto para seus subordinados, mostrando-lhes o que podem extrair e como, da mesma forma, é importante para a organização contribuírem com seus conhecimentos.

Não existe, como já destacado, premiação para acesso ou uso do CLM, mas quando as contribuições são consideradas realmente úteis e passam pelo crivo dos responsáveis pelo projeto no Brasil, a idéia ou sugestão é divulgada por toda organização como o nome do participante. Diversos casos já foram reconhecidos na subsidiária.

A alta administração acredita que o projeto está conseguindo atingir seus objetivos propostos e percebe como crucial o momento atual e o contorno da objeção de falta de tempo.

Um ponto importante que o diretor destaca é que o projeto surgiu num momento que a empresa já tinha grande maturidade com iniciativas em gestão do conhecimento, em que os erros anteriores serviram de aprendizado e as pesquisas formais, realizadas anteriormente ao início do projeto, contribuíram para sua validade e aceitação e, por fim, a tecnologia empregada é extremamente simples e de domínio geral.

\subsection{Considerações finais}

Como já demonstrado, a empresa estudada faz parte de um setor da economia muito concorrido e competitivo, os grandes investimentos em pesquisa e desenvolvimento de novas drogas são determinantes para o sucesso futuro das empresas deste setor. 
A regulamentação de mercado e a pressão por menores preços são características do setor farmacêutico encontradas em diversos países e não diferente no Brasil.

A alta competitividade faz com que a indústria farmacêutica mundial seja uma indústria de vanguarda e utilize ferramentas de gestão de última geração. Isso, porém, não é garantia de sucesso. O sucesso real se mostrará nos resultados financeiros da empresa, para os quais uma força de trabalho comprometida e qualificada é imprescindível.

Na organização estudada não é diferente. Existe um grande número de ferramentas que são utilizadas para percorrer a estratégia competitiva e alcançar liderança nos mercados em que atua.

Para tal a organização vem empregando há algum tempo ferramentas de gestão do conhecimento e garante que isso não é fruto de modismos que as consultorias vendem na matriz da empresa e todas as subsidiárias precisam implementar.

Uma prova disso é o fato de a organização não ter feito alteração nenhuma em sua estrutura organizacional em decorrência dos esforços voltados para gestão do conhecimento.

A gestão do conhecimento é de responsabilidade de um comitê multidisciplinar, tanto nacional como corporativo, e nenhum funcionário se dedica apenas ao tema com exclusividade. Todo líder de projeto de gestão do conhecimento tem sua função preservada.

A empresa vem aprendendo com o tempo que a tecnologia deve vir para servir as pessoas de informações e, principalmente, conhecimento. Isso não aconteceu rapidamente. Foi possível observar nas entrevistas exemplos de projetos que foram implementados sem a total aceitação do usuário final e não resultaram no sucesso esperado.

A gestão do conhecimento na organização é vista de uma abordagem sóciotécnica, sua cultura é bastante forte com traços marcantes que foram impressos por seus fundadores há mais de cem anos.

A empresa considera importante a inter-relação entre pessoas e tecnologia de informação de ponta. Percebe que não pode descartar o uso da tecnologia, mas percebe também que a necessidade e a validade do uso da tecnologia primeiro precisam ser criadas no usuário. 
O assunto gestão do conhecimento é considerado como tema estratégico para o momento atual da organização e há uma preocupação para que a cultura da empresa esteja sempre voltada para o conhecimento, sua transferência e criação.

No projeto CLM especificamente é possível observar elementos básicos e primordiais da gestão do conhecimento. O projeto está voltado para identificar o conhecimento que as pessoas detêm, transferi-los por toda a organização e em seguida colocá-lo em uso.

Porém o fator mais importante encontrado no projeto é a intenção de formar um contexto organizacional em que as pessoas criem conhecimentos novos constantemente.

O projeto está baseado em um modelo de competências e comportamentos que aborda um conjunto de competências individuais necessárias ao negócio e um conjunto de comportamentos que construa um ambiente de trabalho produtivo. Neste modelo estão inseridas as características culturais mais importantes da organização com seus valores e normas.

Quando um funcionário acessa e usa o conhecimento disponibilizado no CLM está tendo contato direto com valores que a organização defende.

O papel da área de recursos humanos no projeto foi preponderante. O projeto foi desenvolvido pela área de recursos humanos corporativo da empresa e no Brasil é coordenado por um gerente de recursos humanos com apoio e suporte de um gerente de tecnologia de informação.

A gestão de recursos humanos da organização está estruturada como um parceiro estratégico na prestação de serviços às demais áreas da empresa na busca dos resultados de negócio. Sua atuação é mais estratégica que operacional, e tem participação efetiva nas estratégias corporativas.

Tanto as práticas de recursos humanos como as de gestão de conhecimento empregadas na organização procuram atender algum objetivo constante no plano estratégico da empresa.

A empresa sabe que tem um volume de processos considerável e que o fator falta de tempo disponível dos funcionários pode ser crítico no projeto CLM e em outros.

O projeto está implementado desde 2002 e as estatísticas de uso, de forma geral, demonstram bom resultados. Embora o projeto seja de âmbito mundial, não se identificam dificuldades de uso por esse motivo. A sua implementação contou com o 
aprendizado de implementação de outros projetos e, desde seu início, com apoio dos usuários. 


\section{CONSIDERAÇÕES FINAIS}

Esta pesquisa teve como princípio realizar uma investigação e análise em uma organização que empregasse esforços em iniciativas de gestão do conhecimento.

De forma mais estrita, esta pesquisa procurou identificar a importância que a gestão de recursos humanos tem para que as iniciativas em gestão do conhecimento sejam bem sucedidas.

Para o desenvolvimento destes temas buscou-se estudar os fundamentos da teoria sobre gestão de pessoas e gestão do conhecimento, para permitir uma investigação e análise empíricas.

Observaram-se, na parte teórica do trabalho, sobretudo nos Capítulos 3 e 4, os pontos relevantes, destacados na literatura, em que a gestão de pessoas possa suportar as iniciativas em gestão do conhecimento. Foram relatados os diversos tópicos encontrados na bibliografia que retratam a atuação da área de recursos humanos para que uma determinada organização construa ambiente e cultura internos que a tornem mais orientada para a criação de conhecimento organizacional.

A maior contribuição observada no estudo de caso, é a constatação de alguns aspectos observados na bibliografia pesquisada. A construção do projeto CLM tem como base um modelo de competências, neste modelo desenvolvido pela empresa estuda tem suporte na visão do seu fundador. A visão dos fundadores e administradores é um dos fatores que contribui para a sedimentação da cultura organizacional.

Neste caso observado, a área de recursos humanos da organização conseguiu transferir para o modelo de competências todos os valores e normas que regem a empresa, mostrando aos funcionários características claras de quais são os princípios fundamentais que ali são considerados importantes e valorizados.

Dentro deste contexto do modelo de competências é observado que existem premissas claras de atitudes, habilidades e conhecimentos que podem ser aprendidas e 
desenvolvidas através da plataforma do CLM. O interessado consegue estabelecer um programa individual de desenvolvimento na competência que mais lhe interessa naquele momento e planejar o seu autodesenvolvimento.

Como observado, o modelo de competências que dá suporte ao CLM é composto por dois grupos principais de competências: competências individuais e competências que proporcionem um ambiente de trabalho produtivo. Dentro do grupo de competências individuais são encontradas competências de desenvolvimento pessoal e de desenvolvimento de negócios, já no grupo de competências de criação de um ambiente de trabalho produtivo podem ser encontradas competências úteis para o desenvolvimento dos subordinados e competências de comunicação.

Com a forte utilização de tecnologia de informação, a área de recursos humanos desenvolveu uma plataforma que contempla as características das iniciativas em gestão do conhecimento, sobretudo a identificação e transferência do conhecimento. Porém, o mais importante que se observa é que existe, no conteúdo do projeto, tópicos que reforçam a sedimentação da cultura da organização através da explicitação dos seus valores, normas e princípios.

As principais observações destacadas da literatura que este trabalho procurou identificar na organização estudada foram as seguintes:

- $\quad$ as práticas e políticas de recursos humanos influenciam a implementação de projetos em gestão do conhecimento.;

- a área de recursos humanos tem três papéis principais para contribuir com um ambiente favorável à gestão do conhecimento:

o recursos humanos atua como parceiro estratégico alinhando sua atuação com a estratégia empresarial;

o recursos humanos participa do aumento das competências e comprometimento dos funcionários;

o recursos humanos é um agente da mudança cultural da organização para que as iniciativas em gestão do conhecimento tenham mais aceitabilidade.

- a área de recursos humanos deve participar ativamente das iniciativas em gestão do conhecimento. 
Foi possível observar que, na organização estudada, existe forte ligação entre recursos humanos e a estratégia adotada pela empresa. A área se posiciona de forma a prestar serviços às demais áreas da organização fazendo com que a busca por melhores resultados de negócios seja compromisso de toda a empresa.

Para que isto seja atingido todas as práticas e políticas de recursos humanos estão alinhadas com a estratégia empresarial. Isso pôde ser constatado de forma prática, pois na empresa estudada é possível observar a atuação da área de recursos humanos em temas estratégicos como:

- participação em comitê executivo que delibera sobre as principais decisões empresariais;

- participação do planejamento estratégico da organização;

- representação em diversos comitês da organização que definem os mais diversos assuntos da empresa;

- gerenciamento de programas de planejamento da força de trabalho, avaliação de habilidades, plano de carreira, diversidade e treinamento;

- capacitação de todos os gestores da organização para que efetivamente pratiquem a gestão de pessoas que a empresa defende;

- integração com os gestores da empresa atuando como parceiros para garantir a ocorrência de um processo unificado das práticas adotadas.

Quanto à atuação da área de recursos humanos contribuindo para o aumento das competências e comprometimento dos funcionários, notou-se que a área tem como responsabilidade, sempre em conjunto com os gerentes de linha, de tornar viável a obtenção das competências que a organização necessita.

O departamento de recursos humanos participa inicialmente como suporte aos gestores para definição das competências necessárias para determinada situação ou função. Em seguida, com apoio das práticas existentes, é definido como a competência será adquirida.

O desenvolvimento de novas competências também é amparado pela gestão de recursos humanos da organização que, sempre em conjunto com os gerentes de linha, define quais as prioridades de treinamento e desenvolvimento. 
O desenvolvimento de competências é feito através de planejamento formal em que cada funcionário pode planejar sua carreira e as competências que precisa desenvolver com apoio de recursos humanos e de seu superior imediato.

O próprio projeto CLM estudado é uma forma encontrada pela gestão de recursos humanos da corporação para que as principais competências e comportamentos que a organização considera importante sejam desenvolvidos.

O processo de avaliação de desempenho na organização é uma oportunidade de análise de como o planejamento da carreira dos funcionários é desenvolvido, para isso existem procedimentos formais e até eletrônicos para que as pessoas dêem e recebam feedbacks.

A retenção de competências também é suportada por recursos humanos. Quanto à retenção das competências e das pessoas que as detêm, as práticas e políticas de remuneração e benefícios procuram ser atrativas para este fim, porém a organização acredita que outros fatores são mais motivacionais, como por exemplo a possibilidade de as pessoas explicitarem seus planos de carreiras e seus objetivos na empresa.

A área de recursos humanos também promove pesquisas junto aos funcionários para que o ambiente de trabalho seja produtivo e para identificar possíveis desvios. Procura promover aos funcionários um equilíbrio entre trabalho e vida pessoal, mesmo que na organização isso nem sempre seja possível. Procura se comunicar de forma clara com todo o grupo e procura se portar como consultor de gestores e funcionários em questões que necessitem de mediação.

No aspecto de a gestão de recursos humanos atuar de forma a ser um agente da mudança cultural da organização, é observado que na empresa estudada a cultura é forte e seus valores transcendem as gestões, sendo, muitos destes valores, definidos pelos fundadores da organização.

Num determinado momento, como resultado de uma pesquisa mundial na organização, a empresa entendeu que precisava tornar estes valores mais fortes e a cultura cada vez mais orientada para o conhecimento. A definição e condução deste processo foi responsabilidade do recursos humanos corporativo.

A resposta foi a formação de um modelo de competências e comportamentos, que dá base ao projeto CLM. Houve a preocupação inicial de mostrar as funcionários que, eles mesmos através da pesquisa, esperavam que os valores fossem mais 
difundidos, desta forma foi criada uma necessidade comum desta mudança e sua validação partiu de baixo para cima.

Quanto à participação ativa da gestão de recursos humanos nas iniciativas em gestão do conhecimento foi constatado que existe uma colaboração da área com os projetos, porém, não existe na organização uma área específica que cuide dos projetos de gestão do conhecimento. Também as iniciativas em gestão do conhecimento não estão subordinadas, na estrutura organizacional, à área de recursos humanos. O fato de não haver uma área específica que cuide somente dos projetos de gestão do conhecimento, mostra alinhamento da organização com as principais observações constatadas na literatura.

Existe um comitê multidisciplinar que é responsável por avaliar os projetos implementados de gestão do conhecimento. Este comitê conta com representantes de diversos departamentos da empresa, inclusive representantes de recursos humanos.

Quanto ao projeto CLM especificamente, é de responsabilidade de recursos humanos porque foi desenvolvido pelo departamento de recursos humanos e conta com apoio da área de tecnologia de informação. Em outros casos segue-se a mesma lógica, a área que necessita do projeto é a responsável por sua manutenção e desenvolvimento, contando com a prestação de serviços da área de tecnologia de informação.

Neste projeto CLM, recursos humanos conseguiu iniciar um processo que promove aprendizagem contínua sobre a cultura da empresa através do modelo de competências e comportamentos no qual a cultura está inserida.

O apoio da alta administração da organização estudada tanto para o projeto CLM como também para a difusão da cultura orientada para o conhecimento é indispensável.

A Figura 6.1 aborda o projeto CLM no contexto organizacional. 


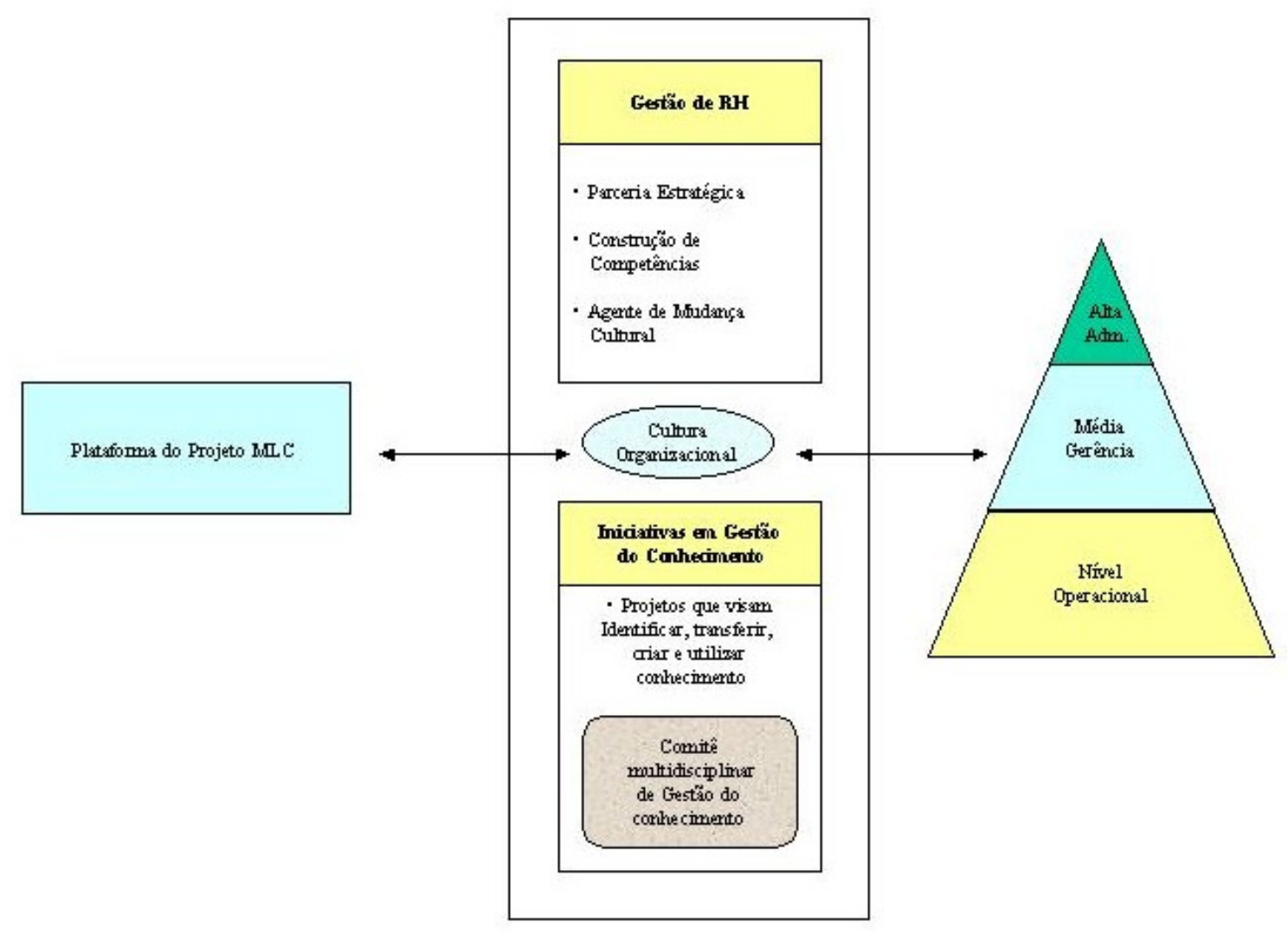

Figura 6.1.-OMLC no contexto organizacional

As inovações tecnológicas, como a introdução do computador pessoal que transformou a indústria da computação e o crescimento da Internet está modificando a indústria da comunicação, transformam a vida das organizações e das pessoas que nela trabalham.

Neste contexto a gestão do conhecimento não é observada como algo novo e sim como um assunto que vem se desenvolvendo no decorrer dos anos por diversas linhas teóricas e a própria evolução dos sistemas de tecnologia de informação.

Percebe-se neste trabalho que um grande fator decisivo para a implementação de programas de gestão do conhecimento diz respeito à cultura da organização. Uma cultura voltada para o conhecimento consegue mostrar aos funcionários que não faz sentido guardar o conhecimento para si.

A detenção de conhecimento é sinônima de poder. Isso não deve mudar tão rapidamente. As pessoas retêm o que sabem por serem os únicos ou poucos a terem aquela informação. Nos negócios de forma tradicional alguns conhecimentos também significam poder contra os concorrentes. E assim devem continuar, como por exemplo, a matriz de um novo produto, a fórmula de um outro. 
Com exceção dos laboratórios de pesquisa, não existe na organização estudada um departamento em que poucos gênios se isolam e guardam consigo a forma de como as coisas são feitas. A gestão do conhecimento é direcionada para orientar a empresa inteira para produzir este que é o bem mais valioso da nova economia e descobrir formas de aproveitá-lo e difundi-lo e, naturalmente, lucrar com ele. Não é possível conseguir isso se a cultura da organização não valorizar atitudes e comportamentos que incluam este ciclo de criação e transferência de conhecimento.

A criação de um ambiente de trabalho produtivo é preocupação da área de recursos humanos da organização estudada. O modelo de competências e comportamentos, no qual o projeto CLM é suportado, descreve comportamentos que valorizam em muito a troca de conhecimentos entre as pessoas de diversas áreas da organização.

A primeira hipótese desta pesquisa: as práticas e políticas de recursos humanos influenciam a implementação de projetos em gestão do conhecimento, é evidenciada na organização estudada. Como esperado, as práticas e políticas de recursos humanos influenciam as iniciativas em gestão do conhecimento.

Esta influência se dá através da constatação dos outros fatores mencionados acima, ou seja, a atuação da área de recursos humanos sobre três aspectos: parceria estratégia, construção de competências e comprometimento e agente da mudança.

A área de recursos humanos tem papel ativo na criação de condições que permitam com que a empresa identifique o conhecimento que já detém, avalie o conhecimento que precisa adquirir e tente comunicar e transferir isso para toda empresa.

O aprendizado com experiências anteriores tem sido importante na organização estudada. Existem casos de projetos que não foram bem sucedidos e os fatos são aproveitados na implementação de outros projetos.

O acúmulo de grande volume de informação também é preocupante e a empresa procura ferramentas para que as contribuições que forem inseridas, especificamente no CLM, sejam válidas e de utilidade. Para isso existe um grupo de pessoas que avalia as contribuições e considera a possibilidade de transmitir aos demais.

Uma outra grande contribuição constatada no estudo de caso é quanto a atuação de recursos humanos em prover educação à gerência média da organização. Praticamente todas as práticas e políticas de recursos humanos da empresa são intermediadas pelos líderes de nível médio. 
Todos eles passam por treinamento constante sobre estas práticas e políticas e começam a atuar em determinada frente após estar devidamente certificado. É o caso de um entrevistador para processos de recrutamento e seleção de candidatos.

Como conseqüência, o processo seletivo visa atrair novos talentos para a organização com habilidades, comportamentos e competências que adicionem valor ao grupo de funcionários.

Na empresa estudada os gerentes de nível médio são considerados imprescindíveis para o sucesso empresarial, estando entre os executores e os estrategistas. É crucial a sua participação para difundir conceitos e fortalecer a cultura organizacional. E, o fato da empresa ter uma hierarquia com poucos níveis, fortalece ainda mais o papel da gerência média.

Na era do conhecimento se dá cada vez mais valor as diferenças pessoais e ao fato de que a diversidade pode trazer benefícios. Na organização estudada o tema diversidade é tratado como assunto atual e todos os funcionários estão passando por um treinamento mundial sobre $o$ assunto.

As pessoas são as detentoras do conhecimento, são elas que de fato fazem com que exista uma nova forma ou abordagem para tratar determinada questão.

O conhecimento é, atualmente, encarado como um dos principais meios de produção, e a sua gestão é assunto que desperta interesse das mais diversas empresas. A questão observada nesta pesquisa é que se o conhecimento é de propriedade da pessoa, esta necessariamente precisa de condições que capacitem o seu entendimento de que a explicitação do que sabe é lucrativa, para ela e para a empresa.

Esta é sem dúvida uma condição cultural e um modelo mental que está sendo modificado com o tempo nas pessoas. $\mathrm{Na}$ organização estudada notou-se que na gerência média isto já está bem sedimentado.

O projeto CLM especificamente também procura valorizar comportamentos para a construção de um ambiente saudável e ético em que as pessoas se sintam valorizadas em compartilhar o seu conhecimento com segurança.

Isso não seria possível sem que práticas de recursos humanos suportassem o discurso. A troca que existe entre empresa e trabalhador é um diagnóstico da função social das organizações.

A empresa se dispõe a prover aos funcionários os recursos disponíveis para que estes tenham prazer e orgulho em trabalhar na organização. Não só vislumbrando-se 
características de remuneração e benefícios, não que estas não sejam importantes, porém organizações do porte da estudada já têm algumas características que estão implícitas quanto à remuneração que cada vez mais está associada à aquisição de competências.

O aspecto mais importante que a organização procura prover ao funcionário é no que diz respeito à satisfação em trabalhar naquele local. As pessoas são tratadas com respeito e dignidade e têm possibilidade de planejar sua carreira. A organização entende que o trabalho exerce papel central na vida dos trabalhadores e percebe que os indivíduos da organização se realizam ao serem criativos e tendo possibilidade de aprender constantemente.

A organização sabe que não é possível aproveitar todos os talentos que dispõe e para isso procura ter processos justos que aumentem a confiança das pessoas em trabalhar na empresa.

Em síntese, durante as observações e entrevistas realizadas na organização notou-se que a atuação da área de recursos humanos facilita a implementação de projetos em gestão do conhecimento, sobretudo pelas características culturais que são imprescindíveis.

Aliás, pode-se notar que a ponte entre a gestão de recursos humanos e a gestão do conhecimento é a cultura organização.

Outro fator importante, observado na organização estudada, é que sua estrutura organizacional elaborada dentro de uma concepção de prestação de serviços e bastante descentralizada, facilitou a implementação de projetos em gestão do conhecimento pelos usuários.

Sua hierarquia com poucos níveis permiti que o acesso aos programas seja feito por todos os funcionários independente de sua função ou posicionamento na empresa.

Pôde-se observar que, de fato, como demonstrado no estudo de caso, a gestão de recursos humanos tem papel fundamental na construção de um ambiente que suporte as iniciativas em gestão do conhecimento.

O pesquisador tem ciência das limitações que o estudo apresenta, não sendo possível extrapolar estas conclusões para outras organizações. Por outro lado é possível confrontar as constatações com as referências encontradas na literatura sobre o assunto e assim a pesquisa tem a função de corroborar com as fontes que tratam do mesmo 
assunto e já apontam para o importante papel que a área de recursos humanos pode desempenhar neste novo cenário de negócios.

Neste novo cenário em que o conhecimento é recurso fundamental, a gestão de recursos humanos tem que realmente ser uma gestão de pessoas, voltada para as pessoas e para sua realização com o trabalho.

A pesquisa abre oportunidade para que novos trabalhos sejam elaborados envolvendo os temas aqui estudados, como: estruturas organizacionais apropriadas para gestão do conhecimento; impacto da gestão do conhecimento em sub áreas de recursos humanos como treinamento, avaliação de desempenho e remuneração com base em competências; análise detalhada das repercussões de gestão do conhecimento sobre formulação de estratégias. 


\section{APÊNDICE A - Roteiro de entrevistas com o gerente de recursos humanos}

Parte 01 - Identificação

01 - Cargo

02 - Área de responsabilidade

03 - Histórico na empresa (tempo de empresa, carreira, tempo na função).

04 - Formação acadêmica

Parte 02 - Gestão de recursos humanos

01 - Qual a estrutura da área de RH na organização?

02 - Como RH diferencia a parte operacional da parte estratégica na organização?

03 - Como se dá o alinhamento das práticas de RH com a estratégia da organização?

04 - Qual a missão e os principais valores que fazem parte da cultura da empresa?

05 - Como são conduzidas as avaliações de desempenho?

06 - A empresa possui algum plano formal de carreiras para os funcionários?

07 - Discorra sobre a política salarial e os principais benefícios praticados pela organização.

08 - Descreva como é conduzida a área de treinamento da empresa.

09 - Descreva como se dá a seleção de candidatos na organização.

10 - Que autonomia é dada aos gerentes para questões sobre gestão de RH?

11 - Na sua opinião qual a principal contribuição da área de RH nas iniciativas em gestão do conhecimento?

12 - Como é o modelo de competências utilizado pela empresa?

Parte 03 - O projeto CLM

01 - Como surgiu o projeto CLM?

02 - Descreva o projeto CLM?

03 - Como foram os primeiros passos para a implementação do projeto no Brasil?

04 - Como tem sido a aceitação do projeto por parte dos funcionários?

05 - A alta gerência apoiou o projeto desde o início?

06 - Quais os principais resultados práticos do uso do projeto no Brasil?

07 - Qual utilidade o projeto tem para o seu trabalho? 


\section{APÊNDICE B - Roteiro de entrevistas com o gerente de tecnologia de informação}

Parte 01 - Identificação

01 - Cargo

02 - Área de responsabilidade

03 - Histórico na empresa (tempo de empresa, carreira, tempo na função).

04 - Formação acadêmica

Parte 02 - Questões sobre gestão do conhecimento

01 - Como está estruturada a área de gestão do conhecimento na empresa?

02 - Quais os principais projetos de gestão do conhecimento em andamento atualmente na empresa?

03 - Qual o entendimento da empresa sobre gestão do conhecimento?

04 - Qual apoio da alta gerência para os projetos de gestão do conhecimento?

05 - Como as iniciativas em gestão do conhecimento estão alinhadas com a estratégia corporativa?

06 - Como as características culturais da organização podem ajudar os projetos de gestão do conhecimento?

07 - Qual a principal contribuição da área de RH para os projetos de gestão do conhecimento?

Parte 03 - O projeto CLM

01 - Como surgiu o projeto CLM?

02 - Descreva o projeto CLM?

03 - Como foram os primeiros passos para a implementação do projeto no Brasil?

04 - Como tem sido a aceitação do projeto por parte dos funcionários?

05 - A alta gerência apoiou o projeto desde o início?

06 - Quais os principais resultados práticos do uso do projeto no Brasil?

07 - Qual utilidade o projeto tem para o seu trabalho? 
APÊNDICE C - Roteiro de entrevistas com os gerentes de vendas, produto, pesquisa clínica e produção.

Parte 01 - Identificação

01 - Cargo

02 - Área de responsabilidade

03 - Histórico na empresa (tempo de empresa, carreira, tempo na função).

04 - Formação acadêmica

Parte 02 - Percepção sobre RH e gestão do conhecimento

01 - Qual a relação entre a sua atividade e a gestão de RH na organização?

02 - Como você percebe a aceitação do seu grupo para as práticas de RH da organização?

03 - Qual o impacto da gestão do conhecimento para sua equipe?

Parte 03 - O projeto CLM

01 - Como você percebe a utilidade do projeto CLM?

02 - Qual a aceitação do seu grupo para com o projeto?

03 - Quais os principais benefícios que o projeto trouxe?

04 - Quais as maiores dificuldades encontradas na utilização do projeto?

05 - Na sua opinião o projeto atingiu os objetivos propostos?

06 - Como você incentiva seus subordinados a utilizarem o projeto CLM? 


\section{APÊNDICE D - Roteiro de entrevistas com o diretor de unidade de negócios}

Parte 01 - Identificação

01 - Cargo

02 - Área de responsabilidade

03 - Histórico na empresa (tempo de empresa, carreira, tempo na função).

04 - Formação acadêmica

Parte 02 - Percepção sobre a gestão de RH e gestão do conhecimento

01 - Como se dá a influência da gestão de RH dentro da sua unidade de negócios?

02 - Qual a participação de RH na definição das estratégias da organização?

03 - Qual o entendimento que a organização tem sobre a gestão do conhecimento?

04 - Como a gestão do conhecimento é empregada em sua unidade?

Parte 03 - O projeto CLM

01 - Como você percebe a utilidade do projeto CLM?

02 - Como você incentiva seus subordinados a utilizarem o projeto CLM?

03 - Quais os principais benefícios que o projeto trouxe?

04 - Quais as maiores dificuldades encontradas para a utilização do projeto?

05 - Na sua opinião o projeto atingiu os objetivos propostos? 